\title{
Synthesis, Characterization, and Comparative Theoretical Investigation of Dinitrogen-Bridged Group 6-Gold Heterobimetallic Complexes
}

\author{
David Specklin, Anaïs Coffinet, Laure Vendier, Iker del Rosal, Chiara Dinoi,* and Antoine Simonneau*
}

Cite This: Inorg. Chem. 2021, 60, 5545-5562

Read Online

ACCESS

Џlll Metrics \& More

回国 Article Recommendations

Supporting Information

ABSTRACT: We have prepared and characterized a series of unprecedented group 6-group 11, $\mathrm{N}_{2}$-bridged, heterobimetallic $\left[\mathrm{ML}_{4}\left(\eta^{1}-\mathrm{N}_{2}\right)\left(\mu-\eta^{1}: \eta^{1}-\mathrm{N}_{2}\right) \mathrm{Au}(\mathrm{NHC})\right]^{+}$complexes $\left(\mathrm{M}=\mathrm{Mo}, \mathrm{W}, \mathrm{L}_{2}\right.$ $=$ diphosphine) by treatment of trans- $\left[\mathrm{ML}_{4}\left(\mathrm{~N}_{2}\right)_{2}\right]$ with a cationic gold(I) complex $[\mathrm{Au}(\mathrm{NHC})]^{+}$. The adducts are very labile in solution and in the solid, especially in the case of molybdenum, and decomposition pathways are likely initiated by electron transfers from the zerovalent group 6 atom to gold. Spectroscopic and structural parameters point to the fact that the gold adducts are very similar to Lewis pairs formed out of strong main-group Lewis acids (LA) and low-valent, end-on dinitrogen complexes, with a bent $\mathrm{M}-\mathrm{N}-\mathrm{N}-\mathrm{Au}$ motif. To verify how far the analogy goes, we computed the electronic structures of $\left[\mathrm{W}(\text { depe })_{2}\left(\eta^{1}\right.\right.$ -

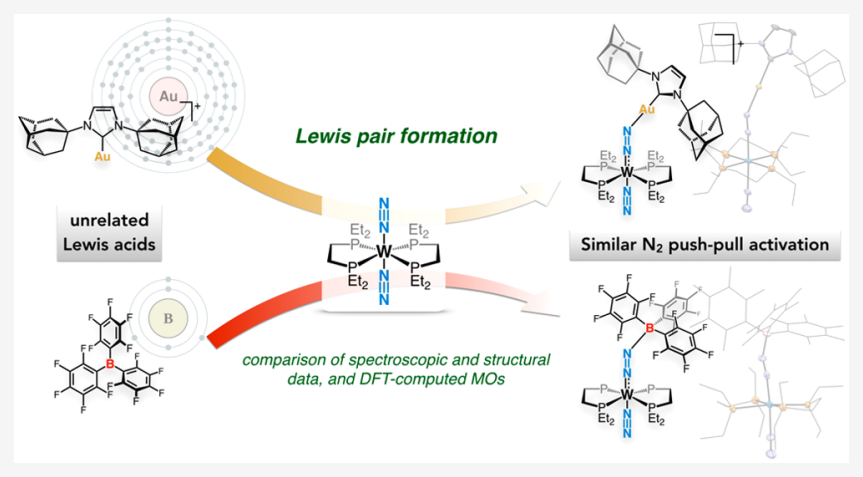
$\left.\mathrm{N}_{2}\right)\left(\mu-\eta^{1}: \eta^{1}-\mathrm{N}_{2}\right)$ AuNHC $]^{+}\left(10_{\mathrm{W}}^{+}\right)$and $\left[\mathrm{W}(\text { depe })_{2}\left(\eta^{1}-\mathrm{N}_{2}\right)\left(\mu-\eta^{1}: \eta^{1}-\mathrm{N}_{2}\right) \mathrm{B}\left(\mathrm{C}_{6} \mathrm{~F}_{5}\right)_{3}\right]\left(\mathbf{1}_{\mathrm{W}}\right)$. A careful analysis of the frontier orbitals of both compounds shows that a filled orbital resulting from the combination of the $\pi^{*}$ orbital of the bridging $\mathrm{N}_{2}$ with a $\mathrm{d}$ orbital of the group 6 metal overlaps in $\mathbf{1 0}_{\mathrm{W}}{ }^{+}$with an empty sd hybrid orbital at gold, whereas in $\mathbf{1}_{\mathbf{W}}$ with an sp ${ }^{3}$ hybrid orbital at boron. The bent $\mathrm{N}-\mathrm{N}-\mathrm{LA}$ arrangement maximizes these interactions, providing a similar level of $\mathrm{N}_{2}$ "push-pull" activation in the two compounds. In the gold case, the HOMO-2 orbital is further delocalized to the empty carbenic p orbital, and an NBO analysis suggests an important electrostatic component in the $\mu-\mathrm{N}_{2}-[\mathrm{Au}(\mathrm{NHC})]^{+}$bond.

\section{INTRODUCTION}

Activation of dinitrogen through its binding to a transition or $\mathrm{f}$ block metal has attracted constant attention from coordination and organometallic chemists for more than 50 years. ${ }^{1}$ Beyond the inherent challenge posed by the high stability of the $\mathrm{N}_{2}$ molecule, investigations on dinitrogen activation have been motivated by the quest for sustainable anthropogenic nitrogen fixation methods that could potentially replace the HaberBosch process. ${ }^{2}$ In this perspective, the nitrogen-fixing enzymes, the nitrogenases, ${ }^{3}$ have inspired chemists as they allow dinitrogen reduction to take place under ordinary pressure and temperature thanks to binding and stepwise reduction of $\mathrm{N}_{2}$ at an iron-containing active site. The understanding of the nitrogenases' mechanism has been in continual progression, but the complexity of the enzyme coupled to the difficulty of its study during substrate consumption leaves the whole mechanistic picture partly speculative. Yet, since the advent of the 2000s, many synthetic $\mathrm{N}_{2}$-to- $\mathrm{NH}_{3}$ catalysts based on transition metals (TMs) have been devised. ${ }^{4}$ Thanks to in-depth mechanistic investigations made possible by the relative simplicity of the catalytic systems, the design of improved catalysts has recently led to high turnover numbers. ${ }^{5}$ In the vast majority of homogeneous nitrogen fixation systems (including the nitrogenases), the $\mathrm{N}_{2}$ molecule is proposed to bind an in situ-generated low-valent metal complex in an end-on fashion as the first step prior to its protonation. When steric hindrance of the ligand sphere allows it, the diatomic $\mathrm{N}_{2}$ molecule can bridge two metals with $\mu$ $\eta^{1}: \eta^{1}$ hapticity, resulting in homobimetallic complexes. $\mathrm{N}_{2}$ bridged heterobimetallic complexes of the transition elements are more scarcely encountered among the literature and only a handful have been completely characterized. Generally, the synthesis of $\mu-\eta^{1}: \eta^{1}-\mathrm{N}_{2}$-bridged heterobimetallic complexes has been aimed at devising original reactivities for the $\mathrm{N}_{2}$ ligand since in such a coordination environment, dinitrogen may be polarized to an extent that is not reached with other coordination modes as a result of "push-pull" activation. ${ }^{6}$ Starting from a mononuclear end-on dinitrogen complex, two synthetic approaches can be envisioned to prepare a $\mathrm{N}_{2^{-}}$

Received: November 16, 2020

Published: March 16, 2021 
bridged heterobimetallic compound, and both take advantage of the basicity imparted to the terminal nitrogen atom of the $\mathrm{N}_{2}$ ligand upon coordination: (i) formation of a Lewis acidbase adduct with a Lewis acidic TM complex and (ii) halide substitution at a high valent TM complex (Scheme 1). The

\section{Scheme 1. Syntheses of $\mathrm{N}_{2}$-Bridged Heterobimetallic} Complexes

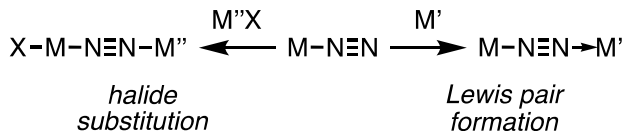

team of Chatt has systematically investigated the coordination of various early d-block Lewis acids through dative bonding with the terminal $\mathrm{N}$ of the $\mathrm{N}_{2}$ ligand of trans- $\left[\mathrm{ReCl}\left(\mathrm{N}_{2}\right)\right.$ $\left.\left(\mathrm{PMe}_{2} \mathrm{Ph}\right)_{4}\right]$ and recorded more or less important bathochromic shifts of the $\nu\left(\mathrm{N}_{2}\right)$ elongation frequency in IR spectroscopy. ${ }^{7}$ The enhanced $\mathrm{N}_{2}$ activation was rationalized according to a push-pull effect, and its magnitude was correlated to the electronic configuration of the acceptor metal. Sellmann et al. have reported the isolation of $\left[\mathrm{Cp}(\mathrm{CO})_{2} \mathrm{Mn}-\right.$ $\left.\left(\mu-\mathrm{N}_{2}\right)-\mathrm{Cr}(\mathrm{CO})_{5}\right]$ from the reaction of $\left[\mathrm{CpMn}(\mathrm{CO})_{2} \mathrm{~N}_{2}\right]$ with $\left[\mathrm{Cr}(\mathrm{CO})_{5}(\mathrm{THF})\right] .{ }^{8}$ Later, the team of Hidai synthesized a series of heterobimetallic $\mathrm{N}_{2}$-bridged complexes by taking advantage of the nucleophilic nature of the $\mathrm{N}_{2}$ ligand in $\mathrm{Mo}^{0}$ and $\mathrm{W}^{0}$ dinitrogen complexes, which substitutes a chloride ligand in high-valent organometallic compounds of groups 4 and 5. ${ }^{9}$ The group of Seymore has characterized an adduct of the trans- $\left[\operatorname{ReCl}\left(\mathrm{N}_{2}\right)\left(\mathrm{PMe}_{2} \mathrm{Ph}\right)_{4}\right]$ compound with a cationic $\mathrm{Mo}^{\text {IV }}$ complex while studying heterolytic $\mathrm{N}_{2}$ splitting. ${ }^{10}$ As far as late transition metal acceptors are concerned, stable heterobimetallic complexes were obtained by the formation of Lewis pairs between a low-valent Mo, Re, or Fe dinitrogen complex and an electrophilic Fe ${ }^{\text {II }}$ complex. ${ }^{11}$ All but one ${ }^{11 b, c}$ of these structurally characterized $\mathrm{N}_{2}$-bridged complexes show a linear $\mathrm{M}-\mathrm{N} \equiv \mathrm{N}-\mathrm{M}^{\prime}$ arrangement as a result of $\mathrm{d}$ orbitals mixing with the $\pi$ molecular orbitals (MOs) of $\mathrm{N}_{2}$.

The formation of $\mathrm{B}\left(\mathrm{C}_{6} \mathrm{~F}_{5}\right)_{3}$ (1) adducts with trans$\left[\mathrm{M}(\text { dppe })_{2}\left(\mathrm{~N}_{2}\right)_{2}\right]\left[\mathrm{M}=\mathrm{Mo}, \mathbf{2}_{\mathrm{Mo}}, \mathrm{M}=\mathrm{W}, \mathbf{2}_{\mathrm{W}}\right.$, dppe $=1,2-$ bis(diphenylphosphino)ethane $]$ and $\left[\mathrm{Fe}(\text { depe })_{2}\left(\mathrm{~N}_{2}\right)\right][$ depe $=$ 1,2-bis(diethylphosphino)ethane] has been reported by us ${ }^{12}$ and the team of Szymczak, ${ }^{11 \mathrm{e}}$ respectively. Characterization of these adducts revealed that $\mathrm{N}_{2}$ activation became significant upon coordination to the strong boron Lewis acid (LA), with a bent $\mathrm{N}-\mathrm{N}-\mathrm{B}$ motif. The Szymczak group rationalized the push-pull effect with the help of DFT calculations and showed that the boron vacant orbital interacts with a $\pi^{*}$ one of the $\mathrm{N}_{2}$ ligand, resulting in a bent structure. Interestingly, these combinations of dinitrogen complexes with main group $\mathrm{LA}^{13}$ have shown unprecedented reactivities toward $\mathrm{N}_{2}$ protonation ${ }^{11 \mathrm{e}}$ or functionalization. ${ }^{12}$ We now wish to extend this $\mathrm{N}_{2}$ complex-LA cooperation paradigm and would like to report herein our studies regarding the formation of stable adducts between zerovalent group 6 dinitrogen complexes and cationic gold(I) complexes. With the purpose of exploiting the reactivity of cationic gold(I) compounds toward unsaturated organic molecules ${ }^{14}$ for $\mathrm{N}_{2}$ functionalization (which turned out to be unproductive), we have, as an interdependent study, examined how $\mathrm{Au}^{\mathrm{I}}$ and $\mathrm{Mo}^{0}$ or $\mathrm{W}^{0}$ complexes interact in the condensed phase. We wanted to answer the following questions: are undesirable redox events likely to occur, and if not, would gold coordinate to the $\mathrm{N}_{2}$ ligand and how? As mentioned above, reactions of early to-mid LA-TMs with $\mathrm{N}_{2}$ complexes have been explored thoroughly and mainly resulted in the formation of adducts. By contrast, and to the best of our knowledge, nothing is known with late, beyond group 8 LATMs, with the exception of $\mathrm{Cu}^{\mathrm{II}}$ and $\mathrm{Ag}^{\mathrm{I}}$ salts, which have been reported to quantitatively oxidize the $\mathrm{Re}^{\mathrm{I}}-\mathrm{N}_{2}$ complex trans$\left[\operatorname{ReCl}\left(\mathrm{N}_{2}\right)\left(\mathrm{PMe}_{2} \mathrm{Ph}\right)_{4}\right]$. $^{7 a}$ Structural, theoretical, and stability data are thus desirable for who wishes to exploit the reactivity of late TMs for the cooperative activation of $\mathrm{N}_{2}$. Moreover, the isolobal relationship existing between $\mathrm{Au}^{+}$and $\mathrm{H}^{+15}$ makes the putative adducts relevant models to assess the effect of acidic residues on ligating $\mathrm{N}_{2}$ within the active site of the nitrogenases and would come to complement the studies carried out by the Szymczak group, ${ }^{11 e, 16}$ whereas the paucity of reports of stable, genuine gold $-\mathrm{N}_{2}$ complexes in the literature ${ }^{17}$ provides further incentive to such investigations. Finally, the above-mentioned $\mathrm{B}\left(\mathrm{C}_{6} \mathrm{~F}_{5}\right)_{3}$-dinitrogen complexes can be well viewed as mixed metal/main group frustrated Lewis pairs (FLPs) ${ }^{18}$ activating the $\mathrm{N}_{2}$ molecule. Replacing boron with gold would introduce an "all-metal" FLP system ${ }^{19}$ for $\mathrm{N}_{2}$ activation. $^{20,21}$ In this Article, we wish to report on the synthesis and structural, spectroscopic, and electronic characterization of $[\mathrm{M}-\mathrm{N} \equiv \mathrm{N}-\mathrm{Au}]^{+}$adducts of $\mathrm{Au}^{\mathrm{I}}$ cations bearing $\mathrm{N}$-heterocyclic carbene ligands (NHC) with group 6 (Mo, W) $\mathrm{N}_{2}$ complexes.

\section{EXPERIMENTAL SECTION}

Computational Details. Calculations were carried out using the Gaussian 09 package $^{22}$ at the DFT level by means of the hybrid density functional B3PW91. ${ }^{23}$ Polarized all-electron double- $\zeta 6$ $31 \mathrm{G}(\mathrm{d}, \mathrm{p})$ basis sets were used for H, C, N, P, B, and F atoms. For the $\mathrm{W}$ and $\mathrm{Au}$ atoms, the Stuttgart-Dresden pseudopotentials were used in combination with their associated basis sets ${ }^{24}$ augmented by a set of polarization functions (f-orbital polarization exponents of 0.823 and 1.05 for the $\mathrm{W}$ and $\mathrm{Au}$ atoms, respectively). ${ }^{25}$ The nature of the optimized stationary point has been verified by means of analytical frequency calculation at $298.15 \mathrm{~K}$ and $1 \mathrm{~atm}$. The geometry optimizations have been achieved without any geometrical constraints and include dispersion with the D3 version of Grimme's dispersion with Becke-Johnson damping. ${ }^{26}$ Energy data are reported in the gas phase. The electron density and partial charge distribution were examined in terms of localized electron-pair bonding units using the NBO program. ${ }^{27}$

General Considerations. All reactions were performed in flameor oven-dried glassware with rigorous exclusion of air and moisture, using a nitrogen filled Jacomex glovebox $\left(\mathrm{O}_{2}<0.5 \mathrm{ppm}, \mathrm{H}_{2} \mathrm{O}<1\right.$ $\mathrm{ppm}$ ). Solvents used were predried (toluene and $n$-pentane by passing through a Puresolv MD 7 solvent purification machine; $n$-hexane and hexamethyldisiloxane (HMDSO) by distillation over $\mathrm{CaH}_{2}$ ), degassed by freeze-pump-thaw cycles, dried over molecular sieves, and stored in the glovebox. $\mathrm{C}_{6} \mathrm{D}_{6}, \mathrm{C}_{6} \mathrm{D}_{5} \mathrm{Cl}$, and THF- $d_{8}$ (purchased from Eurisotop) were degassed by freeze-pump-thaw cycles, dried over molecular sieves, and stored in the glovebox. The Mo/W dinitrogen complexes $\mathbf{2}_{\mathrm{M}}-\mathbf{4}_{\mathrm{M}}{ }^{28}{ }^{15} \mathrm{~N}-\mathbf{3}_{\mathrm{W}},{ }^{28}$ [Au $\left(\mathrm{NTf}_{2}\right)\left(\mathrm{Me}_{2}\right.$ Idipp $\left.)\right](\mathbf{6 b N T f})_{2}{ }^{29}$ and $\mathrm{B}\left(\mathrm{C}_{6} \mathrm{~F}_{5}\right)_{3}(\mathbf{1})^{30}$ were prepared according to reported procedures and stored in the glovebox. The $[\mathrm{Au}(\mathrm{Cl})(\mathrm{NHC})]$ complexes $6 \mathrm{a}-\mathrm{eCl}$ dimethylphenylphosphine ( $\left.\mathrm{PMe}_{2} \mathrm{Ph}\right)$, 1,2-bis(diphenylphosphino)ethane (dppe), 1,2-bis(diethylphosphino)ethane (depe), and NaB$\left(\mathrm{C}_{6} \mathrm{H}_{3}-3,5-\left\{\mathrm{CF}_{3}\right\}_{2}\right)_{4}$ were purchased from TCI, Sigma-Aldrich, or Strem Chemicals and used as received. ${ }^{1} \mathrm{H},{ }^{11} \mathrm{~B},{ }^{13} \mathrm{C},{ }^{19} \mathrm{~F}$, and ${ }^{31} \mathrm{P}$ NMR spectra were recorded using NMR tubes equipped with J. Young valves on a Bruker Avance III 400 spectrometer. Chemical shifts are in parts per million (ppm) downfield from tetramethylsilane and are referenced to the most upfield residual solvent resonance as the internal standard $\left(\mathrm{C}_{6} \mathrm{HD}_{5}: \delta\right.$ reported $=7.16 \mathrm{ppm} ; \mathrm{C}_{6} \mathrm{HD}_{4} \mathrm{Cl}: \delta$ reported $=6.96 \mathrm{ppm}$; THF- $d_{7}: \delta$ reported $=1.72 \mathrm{ppm}$ for ${ }^{1} \mathrm{H}$ NMR; $\mathrm{C}_{6} \mathrm{D}_{5} \mathrm{Cl}: \delta$ reported $=125.96 \mathrm{ppm}$ for $\left.{ }^{13} \mathrm{C} \mathrm{NMR}\right) .{ }^{11} \mathrm{~B},{ }^{19} \mathrm{~F}$, and ${ }^{31} \mathrm{P}$ 
NMR spectra were calibrated according to the IUPAC recommendation using a unified chemical shift scale based on the proton resonance of tetramethylsilane as primary reference. ${ }^{31}$ Data are reported as follows: chemical shift, multiplicity $(\mathrm{br}=$ broad, $\mathrm{s}=$ singlet, $\mathrm{d}=$ doublet, $\mathrm{t}=$ triplet, $\mathrm{q}=$ quartet, $\mathrm{p}=$ quintet, hept $=$ heptuplet, $\mathrm{m}=$ multiplet), coupling constant $(\mathrm{Hz})$, and integration. Infrared (IR) spectra were recorded in a nitrogen filled Jacomex glovebox $\left(\mathrm{O}_{2}<0.5 \mathrm{ppm}, \mathrm{H}_{2} \mathrm{O}<1 \mathrm{ppm}\right)$ on an Agilent Cary $630 \mathrm{FT}$ IR spectrophotometer equipped with ATR or transmission modules and are reported in wavenumbers $\left(\mathrm{cm}^{-1}\right)$ with $(\mathrm{s})$ indicating strong absorption. Elemental analyses were performed on samples sealed in tin capsules under $\mathrm{Ar}$ or $\mathrm{N}_{2}$ by the Analytical Service of the Laboratoire de Chimie de Coordination; results are the average of two independent measurements.

Spectroscopic Characterization of $\left[W(d p p e)_{2}\left(N_{2}\right)\left(\mu-N_{2}\right) A u-\right.$ (Idipp)][B( $\left.\left.\mathrm{C}_{6} \mathrm{H}_{3}-3,5-\left\{\mathrm{CF}_{3}\right\}_{2}\right)_{4}\right] \quad\left(7 a_{W} B A r^{F}\right)$. NMR characterization: $\mathrm{C}_{6} \mathrm{D}_{5} \mathrm{Cl}(0.5 \mathrm{~mL})$ was added at room temperature to a vial containing $[\mathrm{Au}(\mathrm{Cl})(\mathrm{Idipp})](7.4 \mathrm{mg}, 12 \mu \mathrm{mol}), \mathrm{NaB}\left(\mathrm{C}_{6} \mathrm{H}_{3}-3,5-\left\{\mathrm{CF}_{3}\right\}_{2}\right)_{4}(10.6$ $\mathrm{mg}, 12 \mu \mathrm{mol}, 1$ equiv), and $\left[\mathrm{W}(\mathrm{dppe})_{2}\left(\mathrm{~N}_{2}\right)_{2}\right]\left(2_{\mathrm{W}}, 12.4 \mathrm{mg}, 12 \mu \mathrm{mol}\right.$, 1 equiv). The deep orange suspension was then stirred vigorously for 5 min during which the mixture turned to a dark red solution upon formation of the gold adduct. The mixture was then immediately transferred to an NMR tube equipped with a J. Young valve and analyzed via NMR spectroscopy. IR characterization: the same process was conducted with $\mathrm{C}_{6} \mathrm{H}_{5} \mathrm{Cl}$ and transferred into an IR transmission cell for measurement of the $\mathrm{N}_{2}$ ligand region (2400$\left.1600 \mathrm{~cm}^{-1}\right) .{ }^{1} \mathrm{H}$ NMR $\left(400 \mathrm{MHz}, \mathrm{C}_{6} \mathrm{D}_{5} \mathrm{Cl}\right): \delta 8.27(\mathrm{br}, 8 \mathrm{H}, o-\mathrm{H}$, $\left.\mathrm{C}_{6} \mathrm{H}_{3}-3,5-\left(\mathrm{CF}_{3}\right)_{2}\right), 7.61\left(\mathrm{br}, 4 \mathrm{H}, p-\mathrm{H}, \mathrm{C}_{6} \mathrm{H}_{3}-3,5-\left(\mathrm{CF}_{3}\right)_{2}\right), 7.42(\mathrm{t}, J=$ $7.8 \mathrm{~Hz}, 2 \mathrm{H}, p$-Ar dipp), 7.20 (d, $J=7.8 \mathrm{~Hz}, 4 \mathrm{H}, m-\mathrm{Ar} \operatorname{dipp}), 7.14-$ 7.04 (m, 8H, Ar dppe), 7.04-6.91 (m, 16H, Ar dppe), 6.87-6.78 (m, $10 \mathrm{H}$, Ar dppe, $\mathrm{CH}$ imidazole), 6.67 (br, 8H, Ar dppe), 2.38 (hept, $J=$ $\left.7.0 \mathrm{~Hz}, 4 \mathrm{H}, \mathrm{CH}\left(\mathrm{CH}_{3}\right)_{2}\right), 2.28$ (br, $4 \mathrm{H}, \mathrm{CH}_{2} \mathrm{CH}_{2} \mathrm{dppe}$ ), 1.98 (br, $4 \mathrm{H}$, $\mathrm{CH}_{2} \mathrm{CH}_{2}$ dppe $), 1.10\left(\mathrm{~d}, J=6.0 \mathrm{~Hz}, 24 \mathrm{H}, \mathrm{CH}\left(\mathrm{CH}_{3}\right)_{2}\right)$ ppm. ${ }^{11} \mathrm{~B}$ NMR $\left(128 \mathrm{MHz}, \mathrm{C}_{6} \mathrm{D}_{5} \mathrm{Cl}\right): \delta-6.0 \mathrm{ppm} .{ }^{13} \mathrm{C}$ NMR $(100 \mathrm{MHz}$, $\left.\mathrm{C}_{6} \mathrm{D}_{5} \mathrm{Cl}\right): \delta 166.8$ (C carbene), $162.5\left(\mathrm{q}, J_{\mathrm{CF}}=49.9 \mathrm{~Hz}, o-C, \mathrm{C}_{6} \mathrm{H}_{3}\right.$ 3,5- $\left.\left(\mathrm{CF}_{3}\right)_{2}\right), 145.6\left(\mathrm{C}_{\mathrm{Ar}} \operatorname{dipp}\right), 136.7\left(\mathrm{t}, J_{\mathrm{CP}}=9.3 \mathrm{~Hz}, \mathrm{Ar}_{\text {ipso }} \mathrm{dppe}\right)$, 135.3 (br s, o-C, $\left.\mathrm{C}_{6} \mathrm{H}_{3}-3,5-\left(\mathrm{CF}_{3}\right)_{2}\right), 135.0\left(\mathrm{t}, J_{\mathrm{CP}}=9.1 \mathrm{~Hz}, \mathrm{Ar}_{\text {ipso }}\right.$ dppe), $133.7\left(\mathrm{C}_{\mathrm{Ar}} \operatorname{dipp}\right), 132.8\left(\mathrm{t}, J_{\mathrm{CP}}=2.7 \mathrm{~Hz}, o-\operatorname{Ar}\right.$ dppe $), 132.1(\mathrm{t}$, $J_{\mathrm{CP}}=2.4 \mathrm{~Hz}, o-\mathrm{Ar}$ dppe $), 131.3\left(\mathrm{CH}_{\mathrm{Ar}} \operatorname{dipp}\right), 129.8\left(\mathrm{~m}, o-\mathrm{C}, \mathrm{C}_{6} \mathrm{H}_{3}-\right.$ 3,5-( $\left.\left.\mathrm{CF}_{3}\right)_{2}\right), 129.4$ (s, p-Ar dppe), 128.3 (s, p-Ar dppe), 128.2 (hidden, $p$-Ar dppe), $125.0\left(\mathrm{q}, J_{\mathrm{CF}}=272.4 \mathrm{~Hz}, \mathrm{CF}_{3}\right), 124.6\left(\mathrm{CH}_{\mathrm{Ar}}\right.$ dipp), $124.2\left(\mathrm{C}\left(\mathrm{CH}_{3}\right)\right.$ imidazole $), 117.8\left(\mathrm{br}, p-\mathrm{C}, \mathrm{C}_{6} \mathrm{H}_{3}-3,5-\left(\mathrm{CF}_{3}\right)_{2}\right)$, 31.1-30.5 (m, $\mathrm{CH}_{2} \mathrm{CH}_{2}$ dppe), $28.9\left(\mathrm{CH}\left(\mathrm{CH}_{3}\right)_{2}\right), 24.6\left(\mathrm{CH}\left(\mathrm{CH}_{3}\right)_{2}\right)$, $23.6\left(\mathrm{CH}\left(\mathrm{CH}_{3}\right)_{2}\right)$ ppm. ${ }^{19} \mathrm{~F}$ NMR $\left(376 \mathrm{MHz}, \mathrm{C}_{6} \mathrm{D}_{5} \mathrm{Cl}\right): \delta-62.0$ ppm. ${ }^{31} \mathrm{P}$ NMR $\left(162 \mathrm{MHz}, \mathrm{C}_{6} \mathrm{D}_{5} \mathrm{Cl}\right): \delta 45.5\left(J_{\mathrm{PW}}=306.1 \mathrm{~Hz}\right) \mathrm{ppm}$. IR $\left(\mathrm{C}_{6} \mathrm{H}_{5} \mathrm{Cl}, 2400-1600 \mathrm{~cm}^{-1}\right.$ range $), \nu / \mathrm{cm}^{-1}: 2085\left(\mathrm{~N}_{2}\right), 1851(\mu$ $\mathrm{N}_{2}$ ).

Spectroscopic Characterization of $\left[W(\text { dppe })_{2}\left(\mathrm{~N}_{2}\right)\left(\mu-\mathrm{N}_{2}\right) \mathrm{Au}\right.$ $\left.\left(\mathrm{Me}_{2} \text { Idipp)][B(C } \mathrm{C}_{6} \mathrm{H}_{3}-3,5-\left\{\mathrm{CF}_{3}\right\}_{2}\right)_{4}\right]\left(7 \boldsymbol{b}_{W} B A r^{F}\right) . \mathrm{C}_{6} \mathrm{D}_{5} \mathrm{Cl}(0.5 \mathrm{~mL})$ was added at room temperature to a vial containing $\left[\mathrm{Au}(\mathrm{Cl})\left(\mathrm{Me}_{2}\right.\right.$ Idipp $\left.)\right]$ (7.8 mg, $12 \mu \mathrm{mol}), \mathrm{NaB}\left(\mathrm{C}_{6} \mathrm{H}_{3}-3,5-\left\{\mathrm{CF}_{3}\right\}_{2}\right)_{4}(10.6 \mathrm{mg}, 12 \mu \mathrm{mol})$, and [W(dppe $\left.)_{2}\left(\mathrm{~N}_{2}\right)_{2}\right]\left(2_{\mathrm{W}}, 12.4 \mathrm{mg}, 12 \mu \mathrm{mol}\right)$. The deep orange suspension was then stirred vigorously for $5 \mathrm{~min}$ during which the mixture turned to a dark purple solution upon formation of the gold adduct. The mixture was then immediately transferred to an NMR tube equipped with a J. Young valve and analyzed via NMR spectroscopy. FTIR characterization: the same process was conducted with $\mathrm{C}_{6} \mathrm{H}_{5} \mathrm{Cl}$ and transferred into an IR transmission cell for measurement of the $\mathrm{N}_{2}$ ligand region $\left(2400-1600 \mathrm{~cm}^{-1}\right) .{ }^{1} \mathrm{H}$ NMR $\left(400 \mathrm{MHz}, \mathrm{C}_{6} \mathrm{D}_{5} \mathrm{Cl}\right): \delta 8.26\left(\mathrm{br}, 8 \mathrm{H}, o-\mathrm{H}, \mathrm{C}_{6} \mathrm{H}_{3}-3,5-\left(\mathrm{CF}_{3}\right)_{2}\right), 7.61(\mathrm{br}$, $\left.4 \mathrm{H}, p-H, \mathrm{C}_{6} \mathrm{H}_{3}-3,5-\left(\mathrm{CF}_{3}\right)_{2}\right), 7.41(\mathrm{t}, J=7.8 \mathrm{~Hz}, 2 \mathrm{H}, p-\mathrm{Ar} \operatorname{dipp}), 7.27-$ 7.10 (m, 8H, m-Ar dipp, Ar dppe), 7.10-6.91 (m, 20H, Ar dppe), $6.86(\mathrm{t}, J=7.6 \mathrm{~Hz}, 8 \mathrm{H}, \mathrm{Ar}$ dppe), 6.62 (br, $8 \mathrm{H}, \mathrm{Ar}$ dppe), 2.36-2.20 (m, 8H, ${ }^{i}$ Pr dipp, $\mathrm{CH}_{2} \mathrm{CH}_{2}$ dppe), 1.96 (br, $4 \mathrm{H}, \mathrm{CH}_{2} \mathrm{CH}_{2}$ dppe), 1.61 (s, 6H, Me imidazole), 1.10 (d, $J=6.7 \mathrm{~Hz}, 12 \mathrm{H},{ }^{i} \operatorname{Pr}$ dipp), 1.07 (d, $J=$ $6.8 \mathrm{~Hz}, 12 \mathrm{H},{ }^{i} \mathrm{Pr}$ dipp $)$ ppm. ${ }^{11} \mathrm{~B}$ NMR $\left(128 \mathrm{MHz}, \mathrm{C}_{6} \mathrm{D}_{5} \mathrm{Cl}\right): \delta-6.0$ ppm. ${ }^{13} \mathrm{C}$ NMR (100 MHz, $\left.\mathrm{C}_{6} \mathrm{D}_{5} \mathrm{Cl}\right): \delta 162.5$ (C carbene), 162.5 (q, $\left.J_{\mathrm{CF}}=49.6 \mathrm{~Hz}, o-C, \mathrm{C}_{6} \mathrm{H}_{3}-3,5-\left(\mathrm{CF}_{3}\right)_{2}\right), 146.0\left(\mathrm{C}_{\mathrm{Ar}} \operatorname{dipp}\right), 137.3\left(\mathrm{t}, J_{\mathrm{CP}}\right.$ $\left.=9.8 \mathrm{~Hz}, \mathrm{Ar}_{\text {ipso }} \mathrm{dppe}\right), 135.3$ (br s, o-C, $\left.\mathrm{C}_{6} \mathrm{H}_{3}-3,5-\left(\mathrm{CF}_{3}\right)_{2}\right), 134.9(\mathrm{t}$, $J_{\mathrm{CP}}=9.8 \mathrm{~Hz}, \mathrm{Ar}_{\text {ipso }}$ dppe $), 133.0\left(\mathrm{t}, J_{\mathrm{CP}}=2.7 \mathrm{~Hz}, o-\mathrm{Ar}\right.$ dppe $), 132.1$
( $\left.\mathrm{C}_{\mathrm{Ar}} \operatorname{dipp}\right), 132.1\left(\mathrm{t}, J_{\mathrm{CP}}=2.7 \mathrm{~Hz}\right.$, o-Ar dppe $), 131.2\left(\mathrm{CH}_{\mathrm{Ar}} \operatorname{dipp}\right)$, 129.6-129.7 (m, o-C, $\left.\mathrm{C}_{6} \mathrm{H}_{3}-3,5-\left(\mathrm{CF}_{3}\right)_{2}\right), 129.3$ (s, p-Ar dppe), 128.4-128.2 (hidden, $p$-Ar dppe), $127.6\left(\mathrm{C}\left(\mathrm{CH}_{3}\right)\right.$ imidazole), 124.6 $\left(\mathrm{CH}_{\mathrm{Ar}} \operatorname{dipp}\right), 125.0\left(\mathrm{q}, J_{\mathrm{CF}}=272.5 \mathrm{~Hz}, \mathrm{CF}_{3}\right), 117.8\left(\mathrm{br}, p-\mathrm{C}, \mathrm{C}_{6} \mathrm{H}_{3}-\right.$ $\left.3,5-\left(\mathrm{CF}_{3}\right)_{2}\right), 31.0\left(\mathrm{t}, J_{\mathrm{CP}}=10.7 \mathrm{~Hz}, \mathrm{CH}_{2} \mathrm{CH}_{2}\right.$ dppe $), 28.8$ $\left(\mathrm{CH}\left(\mathrm{CH}_{3}\right)_{2}\right), 25.2\left(\mathrm{CH}\left(\mathrm{CH}_{3}\right)_{2}\right), 23.1\left(\mathrm{CH}\left(\mathrm{CH}_{3}\right)_{2}\right), 9.1\left(\mathrm{C}\left(\mathrm{CH}_{3}\right)\right.$ Imidazole) ppm. ${ }^{19} \mathrm{~F}$ NMR $\left(376 \mathrm{MHz}, \mathrm{C}_{6} \mathrm{D}_{5} \mathrm{Cl}\right): \delta-62.1 \mathrm{ppm} .{ }^{31} \mathrm{P}$ NMR $\left(162 \mathrm{MHz}, \mathrm{C}_{6} \mathrm{D}_{5} \mathrm{Cl}\right): \delta 46.2\left(J_{\mathrm{PW}}=307.4 \mathrm{~Hz}\right)$ ppm. IR $\left(\mathrm{C}_{6} \mathrm{H}_{5} \mathrm{Cl}, 2400-1600 \mathrm{~cm}^{-1}\right.$ range $), \nu / \mathrm{cm}^{-1}: 2085\left(\mathrm{~N}_{2}\right), 1851\left(\mu-\mathrm{N}_{2}\right)$.

General Method for the Preparation of $\left[W(\text { depe })_{2}\left(\mathrm{~N}_{2}\right)\left(\mu-\mathrm{N}_{2}\right) \mathrm{Au}-\right.$ $(\mathrm{NHC})]\left[B\left(\mathrm{C}_{6} \mathrm{H}_{3}-3,5-\left\{\mathrm{CF}_{3}\right\}_{2}\right)_{4}\right]$ Adducts $\left(\mathbf{1 0 b}-\boldsymbol{e}_{W} B A r\right) . \mathrm{PhF}(1.5 \mathrm{~mL})$ was added at room temperature to a vial containing $[\mathrm{Au}(\mathrm{Cl})(\mathrm{NHC})]$ (46 $\mu \mathrm{mol}), \mathrm{NaB}\left(\mathrm{C}_{6} \mathrm{H}_{3}-3,5-\left\{\mathrm{CF}_{3}\right\}_{2}\right)_{4}(41 \mathrm{mg}, 46 \mu \mathrm{mol})$, and $\left[\mathrm{W}(\text { depe })_{2}\left(\mathrm{~N}_{2}\right)_{2}\right]\left(3_{\mathrm{W}}, 30 \mathrm{mg}, 46 \mu \mathrm{mol}\right)$. The red suspension was then stirred vigorously for $5 \mathrm{~min}$, during which the mixture turned to a purple $\left(10 b_{W} \mathrm{BAr}^{\mathrm{F}}\right)$ or dark red $\left(10 \mathrm{c}-\mathrm{e}_{\mathrm{W}} \mathrm{BAr} \mathrm{r}^{\mathrm{F}}\right)$ solution upon formation of the adducts. The mixture was then poured in precooled pentane $\left(15 \mathrm{~mL},-40{ }^{\circ} \mathrm{C}\right)$ and stored overnight at $-40{ }^{\circ} \mathrm{C}$ to induce the precipitation of purple or dark red mixtures of the adduct and $\mathrm{NaCl}$ recovered by decantation. The fine $\mathrm{NaCl}$ powder was then stirred up and removed with pentane washes $(3 \times 5 \mathrm{~mL})$ to recover the complexes as red or purple crystals after brief drying under a $\mathrm{N}_{2}$ stream.

$\left[W(\text { depe })_{2}\left(\mathrm{~N}_{2}\right)\left(\mu-\mathrm{N}_{2}\right) A u\left(\mathrm{Me}_{2}\right.\right.$ Idipp $\left.)\right]\left[B\left(\mathrm{C}_{6} \mathrm{H}_{3}-3,5-\left\{\mathrm{CF}_{3}\right\}_{2}\right)_{4}\right]$ $\left(10 b_{w} B A r^{F}\right)$. Recovered as a purple microcrystalline powder $(78 \mathrm{mg}, R$ $=80 \%) .{ }^{1} \mathrm{H}$ NMR $\left(400 \mathrm{MHz}, \mathrm{C}_{6} \mathrm{D}_{5} \mathrm{Cl}\right): \delta 8.26\left(\mathrm{br}, 8 \mathrm{H}, o-\mathrm{H}, \mathrm{C}_{6} \mathrm{H}_{3}-\right.$ 3,5- $\left.\left(\mathrm{CF}_{3}\right)_{2}\right), 7.62\left(\mathrm{br}, 4 \mathrm{H}, p-H, \mathrm{C}_{6} \mathrm{H}_{3}-3,5-\left(\mathrm{CF}_{3}\right)_{2}\right), 7.26(\mathrm{t}, J=7.8 \mathrm{~Hz}$, $2 \mathrm{H}, p$-Ar dipp), 7.08 (d, $J=7.8 \mathrm{~Hz}, 4 \mathrm{H}, m$-Ar dipp), 2.27 (hept, $J=$ $\left.6.9 \mathrm{~Hz}, 4 \mathrm{H},{ }^{i} \mathrm{Pr} \operatorname{dipp}\right), 1.71-1.47\left(\mathrm{~m}, 16 \mathrm{H}, \mathrm{PCH}_{2} \mathrm{CH}_{3}\right), 1.59(\mathrm{~s}, 6 \mathrm{H}$, Me imidazole), $1.23-1.05$ (m, 8H, $\mathrm{CH}_{2} \mathrm{CH}_{2}$ depe), 1.20 (d, $J=6.9$ $\left.\mathrm{Hz}, 12 \mathrm{H},{ }^{i} \mathrm{Pr} \operatorname{dipp}\right), 1.09$ (d, $\left.J=6.9 \mathrm{~Hz}, 12 \mathrm{H},{ }^{i} \mathrm{Pr} \operatorname{dipp}\right), 0.89(\mathrm{~m}, 12 \mathrm{H}$, $\left.\mathrm{PCH}_{2} \mathrm{CH}_{3}\right), 0.74\left(\mathrm{~m}, 12 \mathrm{H}, \mathrm{PCH}_{2} \mathrm{CH}_{3}\right) .{ }^{11} \mathrm{~B}$ NMR $(128 \mathrm{MHz}$, $\left.\mathrm{C}_{6} \mathrm{D}_{5} \mathrm{Cl}\right): \delta-6.1 \mathrm{ppm} .{ }^{19} \mathrm{~F}$ NMR $\left(376 \mathrm{MHz}, \mathrm{C}_{6} \mathrm{D}_{5} \mathrm{Cl}\right): \delta-62.1 \mathrm{ppm}$. ${ }^{31} \mathrm{P}$ NMR $\left(162 \mathrm{MHz}, \mathrm{C}_{6} \mathrm{D}_{5} \mathrm{Cl}\right): \delta 34.2\left(J_{\mathrm{PW}}=296.2 \mathrm{~Hz}\right) \mathrm{ppm}$. IR $\left(\mathrm{C}_{6} \mathrm{H}_{5} \mathrm{Cl}, 2400-1600 \mathrm{~cm}^{-1}\right.$ range $), \nu / \mathrm{cm}^{-1}: 2044\left(\mathrm{~N}_{2}\right), 1796\left(\mu-\mathrm{N}_{2}\right)$. IR (ATR, powder), $\nu / \mathrm{cm}^{-1}: 2960,2936,2065\left(\mathrm{~s}, \mathrm{~N}_{2}\right), 1763\left(\mathrm{~s}, \mu-\mathrm{N}_{2}\right)$, $1647,1610,1595,1495,1461,1416,1395,1353(\mathrm{~s}), 1279(\mathrm{~s}), 1218$, $1165,1117(\mathrm{~s}), 1092,1060,1043,887,867,839,805,785,753,716$, 682, 668. Elem. anal. calcd. for $\mathrm{C}_{81} \mathrm{H}_{100} \mathrm{AuBF}_{24} \mathrm{~N}_{6} \mathrm{P}_{4} \mathrm{~W}$ (\%): C, 45.69; $\mathrm{H}, 4.73$; N, 3.95. Found: C, 45.46; H, 4.73; N, 3.35.

$\left[W(\text { depe })_{2}\left(N_{2}\right)\left(\mu-N_{2}\right) A u(I M e s)\right]\left[B\left(C_{6} H_{3}-3,5-\left\{C F_{3}\right\}_{2}\right)_{4}\right] \quad\left(10 c_{W} B A r^{F}\right)$. Recovered as a dark red microcrystalline powder $(75 \mathrm{mg}, R=$ $85 \%) .{ }^{1} \mathrm{H}$ NMR $\left(400 \mathrm{MHz}, \mathrm{C}_{6} \mathrm{D}_{5} \mathrm{Cl}\right): \delta 8.26\left(\mathrm{br}, 8 \mathrm{H}, o-\mathrm{H}, \mathrm{C}_{6} \mathrm{H}_{3}-3,5-\right.$ $\left.\left(\mathrm{CF}_{3}\right)_{2}\right), 7.62$ (br, $\left.4 \mathrm{H}, p-H, \mathrm{C}_{6} \mathrm{H}_{3}-3,5-\left(\mathrm{CF}_{3}\right)_{2}\right), 6.81$ (s, 4H, Ar Mes), 6.57 (s, 2H, CH imidazole), 2.30 (s, 6H, Me Mes), 2.01-1.82 (m, $\left.8 \mathrm{H}, \mathrm{PCH}_{2} \mathrm{CH}_{3}\right), 1.87$ (s, $\left.12 \mathrm{H}, \mathrm{Me} \mathrm{Mes}\right), 1.80-1.48(\mathrm{~m}, 14 \mathrm{H}$, $\left.\mathrm{PCH}_{2} \mathrm{CH}_{3}, \mathrm{PCH}_{2} \mathrm{CH}_{3}\right), 1.13-1.05\left(\mathrm{~m}, 8 \mathrm{H}, \mathrm{CH}_{2} \mathrm{CH}_{2}\right.$ depe $), 1.05-$ $0.91\left(\mathrm{~m}, 12 \mathrm{H}, \mathrm{PCH}_{2} \mathrm{CH}_{3}\right), 0.81-0.72\left(\mathrm{~m}, 6 \mathrm{H}, \mathrm{PCH}_{2} \mathrm{CH}_{3}\right) .{ }^{11} \mathrm{~B}$ NMR $\left(128 \mathrm{MHz}, \mathrm{C}_{6} \mathrm{D}_{5} \mathrm{Cl}\right): \delta-6.0 \mathrm{ppm} .{ }^{19} \mathrm{~F}$ NMR $\left(376 \mathrm{MHz}, \mathrm{C}_{6} \mathrm{D}_{5} \mathrm{Cl}\right): \delta$ $-62.1 \mathrm{ppm} .{ }^{31} \mathrm{P}$ NMR $\left(162 \mathrm{MHz}, \mathrm{C}_{6} \mathrm{D}_{5} \mathrm{Cl}\right): \delta 32.6\left(J_{\mathrm{PW}}=283.8 \mathrm{~Hz}\right)$ ppm. IR $\left(\mathrm{C}_{6} \mathrm{H}_{5} \mathrm{Cl}, 2400-1600 \mathrm{~cm}^{-1}\right.$ range $), \nu / \mathrm{cm}^{-1}: 2052\left(\mathrm{~N}_{2}\right)$, $1767\left(\mu\right.$ - $\left.\mathrm{N}_{2}\right)$. IR (ATR, powder), $\nu / \mathrm{cm}^{-1}: 2969,2938,2885,2057(\mathrm{~s}$, $\left.\mathrm{N}_{2}\right), 1741\left(\mathrm{~s}, \mu-\mathrm{N}_{2}\right), 1610,1487,1458,1416,1377,1352(\mathrm{~s}), 1271$ (s), 1161, 1118 (s), 1029, 980, 931, 885, 868, 852, 839, 804, 744, 715, 682, 668 (s). Elem. anal. calcd. for $\mathrm{C}_{73} \mathrm{H}_{84} \mathrm{AuBF}_{24} \mathrm{~N}_{6} \mathrm{P}_{4} \mathrm{~W}$ (\%): C, 43.47; H, 4.20; N, 4.17. Found: C, 43.21; H, 4.07; N, 3.21.

$\left[W(\text { depe })_{2}\left(N_{2}\right)\left(\mu-N_{2}\right) A u\left(I^{t} B u\right)\right]\left[B\left(C_{6} H_{3}-3,5-\left\{C_{3}\right\}_{2}\right)_{4}\right]\left(10 d_{W} B A r^{F}\right)$. Recovered as small dark red crystals $(69 \mathrm{mg}, R=81 \%)$. ${ }^{1} \mathrm{H}$ NMR $(400$ $\left.\mathrm{MHz}, \mathrm{C}_{6} \mathrm{D}_{5} \mathrm{Cl}\right): \delta 8.25\left(\mathrm{br}, 8 \mathrm{H}, o-\mathrm{H}_{1} \mathrm{C}_{6} \mathrm{H}_{3}-3,5-\left(\mathrm{CF}_{3}\right)_{2}\right), 7.62(\mathrm{br}, 4 \mathrm{H}$ p- $\left.\mathrm{H}, \mathrm{C}_{6} \mathrm{H}_{3}-3,5-\left(\mathrm{CF}_{3}\right)_{2}\right), 6.64$ (s, 2H, CH imidazole), 2.54-2.40 (m, $\left.2 \mathrm{H}, \mathrm{PCH}_{2} \mathrm{CH}_{3}\right), 2.17-2.01\left(\mathrm{~m}, 4 \mathrm{H}, \mathrm{PCH}_{2} \mathrm{CH}_{3}\right), 1.96-1.81(\mathrm{~m}, 4 \mathrm{H}$, $\mathrm{PCH}_{2} \mathrm{CH}_{3}$ ), $1.73-1.18\left(\mathrm{~m}, 18 \mathrm{H}, \mathrm{PCH}_{2} \mathrm{CH}_{3}, \mathrm{PCH}_{2} \mathrm{CH}_{3}\right), 1.57$ (s, $\left.18 \mathrm{H},{ }^{t} \mathrm{Bu}\right), 1.18-1.01\left(\mathrm{~m}, 17 \mathrm{H}, \mathrm{CH}_{2} \mathrm{CH}_{2}\right.$ depe, $\mathrm{PCH}_{2} \mathrm{CH}_{3}$, $\left.\mathrm{PCH}_{2} \mathrm{CH}_{3}\right), 1.00-0.88\left(\mathrm{~m}, 3 \mathrm{H}, \mathrm{PCH}_{2} \mathrm{CH}_{3}\right) .{ }^{11} \mathrm{~B}$ NMR $(128 \mathrm{MHz}$, $\left.\mathrm{C}_{6} \mathrm{D}_{5} \mathrm{Cl}\right): \delta-6.1 \mathrm{ppm} .{ }^{19} \mathrm{~F}$ NMR $\left(376 \mathrm{MHz}, \mathrm{C}_{6} \mathrm{D}_{5} \mathrm{Cl}\right): \delta-62.1 \mathrm{ppm}$. ${ }^{31} \mathrm{P}$ NMR $\left(162 \mathrm{MHz}, \mathrm{C}_{6} \mathrm{D}_{5} \mathrm{Cl}\right): \delta 34.4\left(J_{\mathrm{PW}}=284.6 \mathrm{~Hz}\right) \mathrm{ppm}$. IR $\left(\mathrm{C}_{6} \mathrm{H}_{5} \mathrm{Cl}, 2400-1600 \mathrm{~cm}^{-1}\right.$ range $), \nu / \mathrm{cm}^{-1}: 2050\left(\mathrm{~N}_{2}\right), 1775\left(\mu-\mathrm{N}_{2}\right)$. IR (ATR, powder), $\nu / \mathrm{cm}^{-1}: 2970,2937,2881,2063\left(\mathrm{~s}, \mathrm{~N}_{2}\right), 1726(\mathrm{~s}$, $\left.\mu-\mathrm{N}_{2}\right), 1609,1487,1459,1409,1379,1351(\mathrm{~s}), 1272(\mathrm{~s}), 1212,1158$, 1116(s), 1037, 898, 885, 866, 838, 805, 744, 710, 681(s), 667(s). 
Elem. anal. calcd. for $\mathrm{C}_{63} \mathrm{H}_{80} \mathrm{AuBF}_{24} \mathrm{~N}_{6} \mathrm{P}_{4} \mathrm{~W}$ (\%): C, 39.98; H, 4.26; N, 4.44. Found: $\mathrm{C}, 39.56$; $\mathrm{H}, 4.19$; $\mathrm{N}, 3.53$.

$\left[W(\text { depe })_{2}\left(N_{2}\right)\left(\mu-N_{2}\right) A u(I A d)\right]\left[B\left(C_{6} H_{3}-3,5-\left\{C_{3}\right\}_{2}\right)_{4}\right]\left(10 e_{W} B A r^{F}\right)$. Recovered as dark brown crystals $(78 \mathrm{mg}, R=83 \%)$. This method allowed the recovery of crystals fit for X-ray diffraction analysis. ${ }^{1} \mathrm{H}$ NMR (400 MHz, $\left.\mathrm{C}_{6} \mathrm{D}_{5} \mathrm{Cl}\right): \delta 8.24\left(\mathrm{br}, 8 \mathrm{H}, o-\mathrm{H}, \mathrm{C}_{6} \mathrm{H}_{3}-3,5-\left(\mathrm{CF}_{3}\right)_{2}\right)$, 7.61 (br, $\left.4 \mathrm{H}, p-\mathrm{H}, \mathrm{C}_{6} \mathrm{H}_{3}-3,5-\left(\mathrm{CF}_{3}\right)_{2}\right), 6.78(\mathrm{~s}, 1 \mathrm{H}, \mathrm{CH}$ imidazole), $6.72(\mathrm{~s}, 1 \mathrm{H}, \mathrm{CH}$ imidazole), 2.53-2.22 (m, 6H, Ad), $2.17(\mathrm{~s}, 8 \mathrm{H}$, Ad), 2.12-1.83 (m, $\left.14 \mathrm{H}, \mathrm{PCH}_{2} \mathrm{CH}_{3}, \mathrm{Ad}\right), 1.83-1.66(\mathrm{~m}, 8 \mathrm{H}$, $\left.\mathrm{PCH}_{2} \mathrm{CH}_{3}, \mathrm{PCH}_{2} \mathrm{CH}_{3}\right), 1.66-1.45\left(\mathrm{~m}, 14 \mathrm{H}, \mathrm{Ad}, \mathrm{PCH}_{2} \mathrm{CH}_{3}\right), 1.43-$ $1.27\left(\mathrm{~m}, 6 \mathrm{H}, \mathrm{PCH}_{2} \mathrm{CH}_{3}\right), 1.15-0.88\left(\mathrm{~m}, 22 \mathrm{H}, \mathrm{PCH}_{2} \mathrm{CH}_{3}, \mathrm{CH}_{2} \mathrm{CH}_{2}\right.$ depe, Ad). ${ }^{11} \mathrm{~B}$ NMR $\left(128 \mathrm{MHz}, \mathrm{C}_{6} \mathrm{D}_{5} \mathrm{Cl}\right): \delta-6.1 \mathrm{ppm} .{ }^{19} \mathrm{~F}$ NMR (376 MHz, $\left.\mathrm{C}_{6} \mathrm{D}_{5} \mathrm{Cl}\right): \delta-62.1 \mathrm{ppm} .{ }^{31} \mathrm{P}$ NMR $\left(162 \mathrm{MHz}, \mathrm{C}_{6} \mathrm{D}_{5} \mathrm{Cl}\right): \delta$ $34.6\left(J_{\mathrm{PW}}=295.3 \mathrm{~Hz}\right) \mathrm{ppm}$. IR $\left(\mathrm{C}_{6} \mathrm{H}_{5} \mathrm{Cl}, 2400-1600 \mathrm{~cm}^{-1}\right.$ range $), \nu /$ $\mathrm{cm}^{-1}: 2048\left(\mathrm{~N}_{2}\right), 1783\left(\mu-\mathrm{N}_{2}\right)$. IR (ATR, powder), $\nu / \mathrm{cm}^{-1}: 2915$, 2859, $2048\left(\mathrm{~N}_{2}\right), 1762\left(\mathrm{~s}, \mu-\mathrm{N}_{2}\right), 1610,1457,1353(\mathrm{~s}), 1274$ (s), 1160, 1122 (s), 1038, 1027, 899, 887, 867, 839, 807, 744, 724, 716, 693, 682(s), 669(s). Elem. anal. calcd. for $\mathrm{C}_{75} \mathrm{H}_{92} \mathrm{AuBF}_{24} \mathrm{~N}_{6} \mathrm{P}_{4} \mathrm{~W}(\%)$ : $\mathrm{C}, 43.96 ; \mathrm{H}, 4.53 ; \mathrm{N}, 4.10$. Found: $\mathrm{C}, 43.40 ; \mathrm{H}, 4.63 ; \mathrm{N}, 3.17$. $\left[\mathrm{W}(\text { depe })_{2}\left({ }^{15} \mathrm{~N}_{2}\right)\left(\mu-{ }^{15} \mathrm{~N}_{2}\right) \mathrm{Au}(\mathrm{IAd})\right]\left[\mathrm{B}\left(\mathrm{C}_{6} \mathrm{H}_{3}-3,5-\left\{\mathrm{CF}_{3}\right\}_{2}\right)_{4}\right]\left({ }^{15} \mathrm{~N}-\right.$ $\left.\mathbf{1 0 e}_{\mathrm{W}} \mathrm{BAr}{ }^{\mathrm{F}}\right) .{ }^{15} \mathrm{~N}$ NMR $\left(60 \mathrm{MHz}, \mathrm{C}_{6} \mathrm{D}_{5} \mathrm{Cl}\right): \delta-40.1\left(\mathrm{~s}, 1 \mathrm{~N}, \mu-\mathrm{N}_{\alpha}\right)$, $-42.9\left(\mathrm{~s}, 1 \mathrm{~N}, \mathrm{~N}_{\beta}\right),-76.1\left(\mathrm{~s}, 1 \mathrm{~N}, \mathrm{~N}_{\alpha}\right),-119.0\left(\mathrm{~s}, 1 \mathrm{~N}, \mu-\mathrm{N}_{\beta}\right) \mathrm{ppm}$. ${ }^{31} \mathrm{P}\left\{{ }^{1} \mathrm{H}\right\} /{ }^{183} \mathrm{~W}$ HMQC-NMR $\left(25 \mathrm{MHz}, \mathrm{C}_{6} \mathrm{D}_{5} \mathrm{Cl}\right): \delta-2031.1 \mathrm{ppm}$. IR (ATR, powder), $\nu / \mathrm{cm}^{-1}: 2914,1977\left(\mathrm{~N}_{2}\right), 1703\left(\mathrm{~s}, \mu-\mathrm{N}_{2}\right), 1458$, 1352 (s), 1303, 1274 (s), 1197, 1161, 1122 (s), 1104, 1038, 1027, 930, 899, 887, 866, 838, 807, 755, 743, 724, 715, 710, 693, 681 (s), $668(\mathrm{~s}), 607$.

Preparation of $\left.\left[\mathrm{Mo}(\text { depe })_{2}\left(\mathrm{~N}_{2}\right)\left(\mu-\mathrm{N}_{2}\right) B\left(C_{6} F_{5}\right)_{3}\right)\right] \quad\left(11_{M o}\right)$. Toluene $(0.6 \mathrm{~mL})$ was added to a $10 \mathrm{~mL}$ flask containing trans-[Mo(depe $\left.)_{2}\left(\mathrm{~N}_{2}\right)_{2}\right]\left(3_{\mathrm{Mo}}, 34 \mathrm{mg}, 60 \mu \mathrm{mol}, 1.0\right.$ equiv) and $\mathrm{B}\left(\mathrm{C}_{6} \mathrm{~F}_{5}\right)_{3}(1,31$ $\mathrm{mg}, 60 \mu \mathrm{mol}, 1.0$ equiv). After stirring for $10 \mathrm{~min}$ at room temperature, the orange-brown mixture was filtered, layered slowly with pentane $(6 \mathrm{~mL})$, and stored at $-40{ }^{\circ} \mathrm{C}$. After 2 days, orange crystals of $\mathbf{1 1}_{\mathrm{Mo}}$ were recovered and dried under a vacuum $(34 \mathrm{mg}$, $53 \%$ yield). Single crystals suitable for X-ray diffraction analysis were obtained from the same crop. ${ }^{1} \mathrm{H}$ NMR $\left(400 \mathrm{MHz}, \mathrm{C}_{6} \mathrm{D}_{6}\right): \delta 1.76-$ $1.28(\mathrm{~m}, 17 \mathrm{H}), 1.17(\mathrm{~m}, 6 \mathrm{H}), 1.03-0.83(\mathrm{~m}, 13 \mathrm{H}), 0.83-0.69(\mathrm{~m}$, $10 \mathrm{H}), 0.67-0.55(\mathrm{~m}, 1 \mathrm{H}), 0.53-0.41(\mathrm{~m}, 1 \mathrm{H}) \mathrm{ppm} .{ }^{11} \mathrm{~B}$ NMR $(128$ $\left.\mathrm{MHz}, \mathrm{C}_{6} \mathrm{D}_{6}\right): \delta-10.1 \mathrm{ppm} .{ }^{19} \mathrm{~F}$ NMR $\left(376.5 \mathrm{MHz}, \mathrm{C}_{6} \mathrm{D}_{6}\right)$, maj (84\%): $\delta-131.9$ (d, $J=21.6 \mathrm{~Hz}, 2 \mathrm{~F}),-158.7(\mathrm{t}, J=20.4 \mathrm{~Hz}, 1 \mathrm{~F})$, $-164.4(\mathrm{t}, J=18.2 \mathrm{~Hz}, 2 \mathrm{~F}) \mathrm{ppm} .{ }^{19} \mathrm{~F}$ NMR $\left(376.5 \mathrm{MHz}, \mathrm{C}_{6} \mathrm{D}_{6}\right)$, min (16\%): $\delta-132.3(\mathrm{~d}, J=19.5 \mathrm{~Hz}, 2 \mathrm{~F}),-159.5(\mathrm{t}, J=20.7 \mathrm{~Hz}, 1 \mathrm{~F})$, $-165.0(\mathrm{t}, J=19.1 \mathrm{~Hz}, 2 \mathrm{~F}) \mathrm{ppm} .{ }^{31} \mathrm{P}\left\{{ }^{1} \mathrm{H}\right\} \mathrm{NMR}\left(162 \mathrm{MHz}, \mathrm{C}_{6} \mathrm{D}_{6}\right): \delta$ $53.0 \mathrm{ppm}$. IR (ATR), $\nu / \mathrm{cm}^{-1}: 2965,2939,2909,2881,2120\left(\mathrm{~N}_{2}\right)$, $1789\left(\mu-\mathrm{N}_{2}\right), 1642,1512,1461,1379,1279,1081,1028,973,867$, $802,748,735,674,666,603,522$. Elem. anal. calcd. for $\mathrm{C}_{38} \mathrm{H}_{48} \mathrm{BF}_{15} \mathrm{MoN}_{4} \mathrm{P}_{4}$ (\%): C, 42.40; H, 4.49; N, 5.20. Found: C, 42.60; H, 4.25; N, 4.47.

Preparation of $\left.\left[W(\text { depe })_{2}\left(N_{2}\right)\left(\mu-N_{2}\right) B\left(C_{6} F_{5}\right)_{3}\right)\right]\left(11_{W}\right)$. Toluene $(1.5$ $\mathrm{mL})$ was added to a $10 \mathrm{~mL}$ flask containing trans- $\left[\mathrm{W}(\text { depe })_{2}\left(\mathrm{~N}_{2}\right)_{2}\right]$ $\left(3_{\mathrm{W}}, 65 \mathrm{mg}, 100 \mu \mathrm{mol}, 1.0\right.$ equiv) and $\mathrm{B}\left(\mathrm{C}_{6} \mathrm{~F}_{5}\right)_{3}(1,51 \mathrm{mg}, 100 \mu \mathrm{mol}$, 1.0 equiv). After stirring for $10 \mathrm{~min}$ at room temperature, the orangebrown mixture was filtered, layered slowly with pentane $(10 \mathrm{~mL})$, and stored at $-40{ }^{\circ} \mathrm{C}$. After 1 week, purple crystals of $\mathbf{1 1}_{\mathrm{W}}$ were recovered and dried under a vacuum $(72 \mathrm{mg}, 62 \%$ yield). Single crystals suitable for X-ray diffraction analysis were obtained from the same crop. ${ }^{1} \mathrm{H}$ NMR (400 MHz, toluene- $\left.d_{8}\right): \delta 1.67-1.28(\mathrm{~m}, 20 \mathrm{H}), 1.22-1.08(\mathrm{br}$, $4 \mathrm{H}), 0.94-0.84(\mathrm{~m}, 12 \mathrm{H}), 0.84-0.70(\mathrm{~m}, 12 \mathrm{H}) \mathrm{ppm} .{ }^{11} \mathrm{~B}$ NMR $(128$ $\left.\mathrm{MHz}, \mathrm{C}_{6} \mathrm{D}_{6}\right): \delta-11.1 \mathrm{ppm} .{ }^{19} \mathrm{~F}$ NMR $\left(377 \mathrm{MHz}\right.$, toluene- $\left.d_{8}\right): \delta$ $-132.0(\mathrm{~d}, J=23.8 \mathrm{~Hz}, 6 \mathrm{~F}),-159.1(\mathrm{t}, J=20.7 \mathrm{~Hz}, 3 \mathrm{~F}),-164.6(\mathrm{td}$, $\mathrm{J}=22.8,7.4 \mathrm{~Hz}, 6 \mathrm{~F}) \mathrm{ppm} .{ }^{31} \mathrm{P}\left\{{ }^{1} \mathrm{H}\right\}$ NMR $\left(162 \mathrm{MHz}, \mathrm{C}_{6} \mathrm{D}_{6}\right): \delta 34.7$ $\left(J_{\mathrm{PW}}=294 \mathrm{~Hz}\right) \mathrm{ppm}$. IR (ATR) $\nu / \mathrm{cm}^{-1}: 2967,2934,2910,2076$ $\left(\mathrm{N}_{2}\right), 1767\left(\mu-\mathrm{N}_{2}\right), 1641,1512,1461,1378,1279,1081,1028,973$, $868,802,749,693,675,612,525$. Elem. anal. calcd. for $\mathrm{C}_{38} \mathrm{H}_{48} \mathrm{BF}_{15} \mathrm{WN}_{4} \mathrm{P}_{4}$ (\%): C, 39.20; H, 4.16; N, 4.81. Found: C, 39.59; H, 4.09; N, 4.08. [W(depe $\left.\left.{ }_{2}\left({ }^{15} \mathrm{~N}_{2}\right)\left(\mu-{ }^{15} \mathrm{~N}_{2}\right) \mathrm{B}\left(\mathrm{C}_{6} \mathrm{~F}_{5}\right){ }_{3}\right)\right]\left({ }^{15} \mathrm{~N}-\right.$ $\left.11_{\mathrm{W}}\right)$. The preparation is identical to that for $\mathbf{1 1}_{\mathrm{W}} \cdot{ }^{15} \mathrm{~N}$ NMR $(60$ $\left.\mathrm{MHz}, \mathrm{C}_{6} \mathrm{D}_{6}\right): \delta-37.4\left(\mathrm{~s}, 1 \mathrm{~N}, \mathrm{~N}_{\beta}\right),-55.0\left(\mathrm{~s}, 1 \mathrm{~N}, \mu-\mathrm{N}_{\alpha}\right),-73.9(\mathrm{~s}, 1 \mathrm{~N}$, $\left.\mathrm{N}_{\alpha}\right),-152.6\left(\mathrm{~s}, 1 \mathrm{~N}, \mu\right.$ - $\left.\mathrm{N}_{\beta}\right)$ ppm. ${ }^{31} \mathrm{P}\left\{{ }^{1} \mathrm{H}\right\} /{ }^{183} \mathrm{~W}$ HMQC-NMR $(25$ $\left.\mathrm{MHz}, \mathrm{C}_{6} \mathrm{D}_{6}\right): \delta-1914.2 \mathrm{ppm}$. IR (ATR), $\nu / \mathrm{cm}^{-1}: 2007\left(\mathrm{~N}_{2}\right), 1767$
$\left(\mu-\mathrm{N}_{2}\right), 1641,1512,1461,1378,1279,1081,1028,973,867,801$, $748,693,675,612$.

\section{RESULTS AND DISCUSSION}

Coordination of $\mathrm{Au}(\mathrm{I})$ Cations to Dinitrogen Complexes. Our study commenced by investigating the formation of heterobimetallic $[\mathrm{M}-\mathrm{N} \equiv \mathrm{N}-\mathrm{Au}]^{+}$adducts between the group $6(\mathrm{Mo}, \mathrm{W})$ dinitrogen complexes $\left[\mathrm{M}(\mathrm{dppe})_{2}\left(\mathrm{~N}_{2}\right)_{2}\right]$ $\left(2_{\mathrm{M}}\right),\left[\mathrm{M}(\text { depe })_{2}\left(\mathrm{~N}_{2}\right)_{2}\right]\left(3_{\mathrm{M}}\right)$, and $\left[\mathrm{M}\left(\mathrm{PMe} \mathrm{P}_{2} \mathrm{Ph}\right)_{4}\left(\mathrm{~N}_{2}\right)_{2}\right]\left(\mathbf{4}_{\mathrm{M}}\right)$ and $\mathrm{Au}(\mathrm{I})$ cations supported by NHC ligands. Due to their strong $\sigma$-donor character and their steric profiles, NHCs are well-known to provide both excellent stabilization of $\mathrm{Au}(\mathrm{I})$ complexes and enhancement of their catalytic activities. ${ }^{32}$ Independently of the ligand, monoligated cationic $\mathrm{Au}(\mathrm{I})$ complexes are notoriously unstable and tend to readily decompose to colloidal gold, precluding their isolations. ${ }^{33}$ Thus, we elected to assess two strategies: (i) reaction of the $\mathrm{N}_{2}$ complexes on $[\mathrm{Au}(\mathrm{Cl})(\mathrm{NHC})]$ to form $\mu-\mathrm{N}_{2}$ heterobimetallic complexes by displacement of the chloride ligand or (ii) generation of monoligated $\mathrm{Au}(\mathrm{I})$ cations in situ in the presence of the $\mathrm{N}_{2}$ complexes (Scheme 2). Considering that $\mathrm{H}^{+}$and $\mathrm{Au}^{+}$

Scheme 2. Synthetic Strategies to Probe the Formation of $[\mathrm{M}-\mathrm{N} \equiv \mathrm{N}-\mathrm{Au}]$ Heterobimetallic Complexes

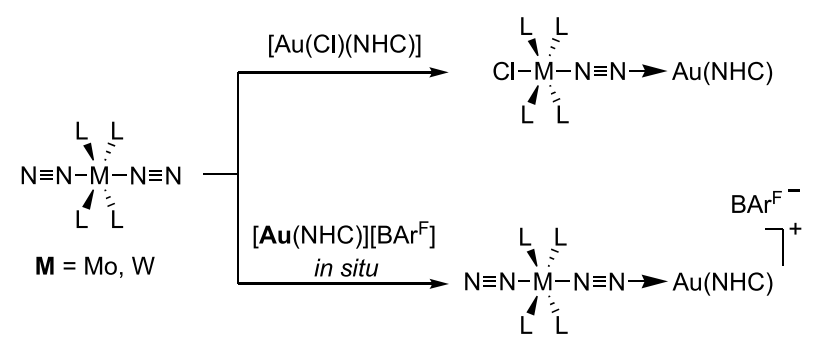

are isolobal, the first approach could be regarded as analogous to reactions of group $6 \mathrm{~N}_{2}$ complexes with $\mathrm{HCl}$, which are known to afford the protonated products $\left[\mathrm{M}(\mathrm{Cl})\left(\mathrm{NNH}_{2}\right)\right.$ $\left.(\mathrm{L})_{4}\right] \mathrm{Cl}^{34}$ The second strategy requires generation of the $\mathrm{Au}(\mathrm{I})$ cation. The standard approach to prepare $[\mathrm{Au}(\mathrm{NHC})]^{+}$ is through the treatment of $[\mathrm{Au}(\mathrm{Cl})(\mathrm{NHC})]$ complexes with the corresponding $\mathrm{Ag}^{+}$salt to form $\mathrm{AgCl}$. However, the exact nature of $[\mathrm{Au}(\mathrm{NHC})]^{+}$complexes in the presence of $\mathrm{Ag}^{+}$has recently been questioned in view of the $\mathrm{Ag}^{+}$effect on catalytic activity and NMR analytic data of some $\mathrm{Au}(\mathrm{I})$ complexes. ${ }^{35}$ Moreover, the redox potential of $\mathrm{Ag} / \mathrm{AgCl}(0.22 \mathrm{~V}$ vs $\mathrm{SHE}$ ) lies above the redox potentials of the dinitrogen complexes considered $\left(2_{\mathrm{M}} \approx 0.09 \mathrm{~V}, \mathbf{3}_{\mathrm{M}} \approx-0.2 \mathrm{~V}\right.$ vs SHE $){ }^{36}$ and adventitious remains of $\mathrm{Ag}^{\mathrm{I}}$ could lead to undesired redox reactions that would compromise the analysis of the reaction's outcome. A more suitable strategy is to form $\mathrm{Au}(\mathrm{I})$ cations by salt metathesis between a sodium salt of an adequate counteranion and $\mathrm{Au}(\mathrm{Cl})(\mathrm{NHC})$ complexes. To avoid competition between the anion and dinitrogen for coordination to the gold center, we used the noncoordinating anion tetrakis(3,5-bis (trifluoromethyl)phenyl) borate $\left(\left[\mathrm{BAr}^{\mathrm{F}}\right]^{-}\right)$. Cationic gold complexes with anions showing low gold affinity such as $\mathrm{BAr}^{\mathrm{F}-}$ have been observed in some cases to have increased catalytic efficiency and equal robustness than salts of more coordinating anions. ${ }^{35,37}$

Reaction of $[A u(C l)(N H C)]$ with $2_{w}$. In tetrahydrofuran- $d_{8}$ $\left(\mathrm{THF}-d_{8}\right), 2_{\mathrm{w}}$ was reacted with 1 equiv of $[\mathrm{Au}(\mathrm{Cl})(\mathrm{Idipp})]$ (see SI for details; Idipp: 1,3-bis(2,6-diisopropylphenyl)imidazolin-2-ylidene). Over $18 \mathrm{~h}$ at $75{ }^{\circ} \mathrm{C}$, the ${ }^{1} \mathrm{H}$ NMR 
signature of $2_{\mathrm{W}}$ slowly disappeared concomitantly with the formation of a well-defined new set of signals for the Idipp moiety and clear markers of the buildup of paramagnetic species such as numerous broad signals in ${ }^{1} \mathrm{H}$ NMR and a loss of signals in ${ }^{31} \mathrm{P}$ NMR. X-ray diffraction study on dark red crystals that precipitated out of the solution allowed to characterize the $\mathrm{W}(\mathrm{I}), \mathrm{Au}(\mathrm{I})$ salt $\left[\mathrm{W}(\mathrm{Cl})_{2}(\mathrm{dppe})_{2}\right][\mathrm{Au}-$ (Idipp) $)_{2}\left(5_{\mathrm{W}}\right)$ as one of the products of the reaction (isolated in $32 \%$ yield relative to $\mathrm{W}$ content; Figure 1). Further heating
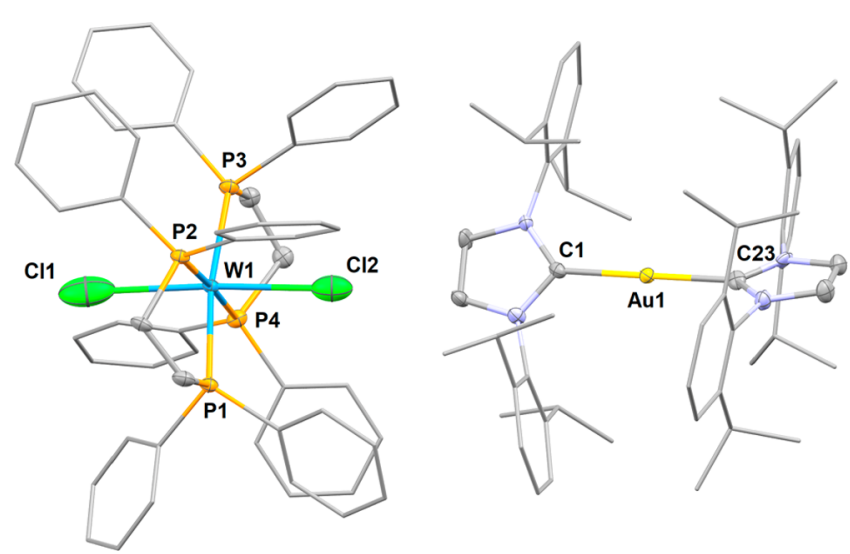

Figure 1. Molecular structure of complex $5_{\mathrm{W}}$ in the solid state (ellipsoids are drawn at the $50 \%$ probability level, ligand substituents are drawn with wireframe, and hydrogen atoms are omitted for clarity). Selected bond lengths (A) and angles (deg): C1-Aul 2.033(4), C23-Au1 2.026(4), Cl1-W1 2.732(3), Cl2-W1 2.6674(19), P1-W1 2.4108(11), P2-W1 2.4188(11), P3-W1 2.4308(11), P4-W1 2.4408(11), C1-Au1-C23 179.36(18), Cl1$\mathrm{W}-\mathrm{Cl} 2176.41$.

of the reaction mixture led to the deposition of the $\mathrm{W}(\mathrm{II})$ complex $\left[\mathrm{W}(\mathrm{Cl})_{2}(\mathrm{dppe})_{2}\right]$ as bright red crystals (up to $18 \%$ yield relative to $\mathrm{W}$ content after 3 days at $75{ }^{\circ} \mathrm{C}$ ).

The $\left[\mathrm{W}\left(\mathrm{Cl}_{2}\right)_{2}(\mathrm{dppe})_{2}\right]^{-}$anion of $5_{\mathrm{W}}$ lies in a slightly distorted octahedral geometry with two chloride ligands in a trans relationship. The formal $+\mathrm{I}$ oxidation state of the tungsten is inferred from charge balance and from the dimension of the $\mathrm{WCl}_{2} \mathrm{P}_{4}$ core, which follows the tendency established between the isostructural neutral complex of W(II) and the cationic complex of W(III) (shorter W-P distances and longer $\mathrm{W}-\mathrm{Cl}$ distances for decreasing oxidation states). ${ }^{38}$ The structural parameters of the cation are comparable to those reported for $\left[\mathrm{Au}(\mathrm{Idipp})_{2}\right]\left[\mathrm{BF}_{4}\right] .{ }^{39}$ The gold(I) center bears two Idipp ligands in a linear geometry, arranged with a $47.95^{\circ}$ torsion angle between the imidazolyl planes to minimize the steric repulsion between the carbene fragments. Evidently, two equivalents of $[\mathrm{Au}(\mathrm{Cl})$ (Idipp) $]$ are necessary for the formation of $5_{\mathrm{W}}$ and $\left[\mathrm{W}(\mathrm{Cl})_{2}(\mathrm{dppe})_{2}\right]$, the former producing a $\mathrm{Au}(0)$ species that has not been identified. However, reacting $2_{\mathrm{w}}$ with 2 equiv of $[\mathrm{Au}(\mathrm{Cl})(\mathrm{Idipp})]$ does not increase the yield of these complexes significantly, indicating that there are multiple pathways to the formation of paramagnetic species and decomposition of the $\mathrm{Au}(\mathrm{I})$ cation. No reaction takes place at room temperature or in a less coordinating solvent (in the latter case owing to the poor solubility of $[\mathrm{Au}(\mathrm{Cl})(\mathrm{Idipp})])$. Thus, even if a reactivity similar to $\mathrm{HCl}$ could take place to form complexes such as $\left[\mathrm{W}(\mathrm{Cl})(\mathrm{dppe})_{2}\left(\mu-\mathrm{N}_{2}\right)(\mathrm{Au}(\mathrm{Idipp})]\right.$, the harsh conditions necessary to form them favors in fine electronic transfer reactions.
Generation of Monoligated Au(I) Cation in Situ. We then investigated a series of $[\mathrm{Au}(\mathrm{NHC})]^{+}$cations $\left(6^{+}\right.$; Scheme 3$)$ for their coordination to $\mathrm{N}_{2}$ complexes $\mathbf{2}_{\mathrm{M}}, \mathbf{3}_{\mathrm{M}}$, and $\left[\mathrm{M}\left(\mathrm{PMe}_{2} \mathrm{Ph}\right)_{4}\left(\mathrm{~N}_{2}\right)_{2}\right] \quad\left[\mathrm{M}=\mathrm{Mo}, \mathbf{4}_{\mathrm{Mo}}(80: 20\right.$ cis $/$ trans mixture); $\mathrm{M}=\mathrm{W}, \mathbf{4}_{\mathrm{W}}$ (only cis)].

Scheme 3. Group 6 Dinitrogen Complexes Surveyed (Top, $\mathbf{M}=\mathbf{M o}$ or $\mathrm{W})$ and Formation of $[\mathrm{Au}(\mathrm{NHC})]\left[\mathrm{BAr}^{\mathrm{F}}\right]$ Salts and Selection of the NHCs Used in This Work (Bottom)
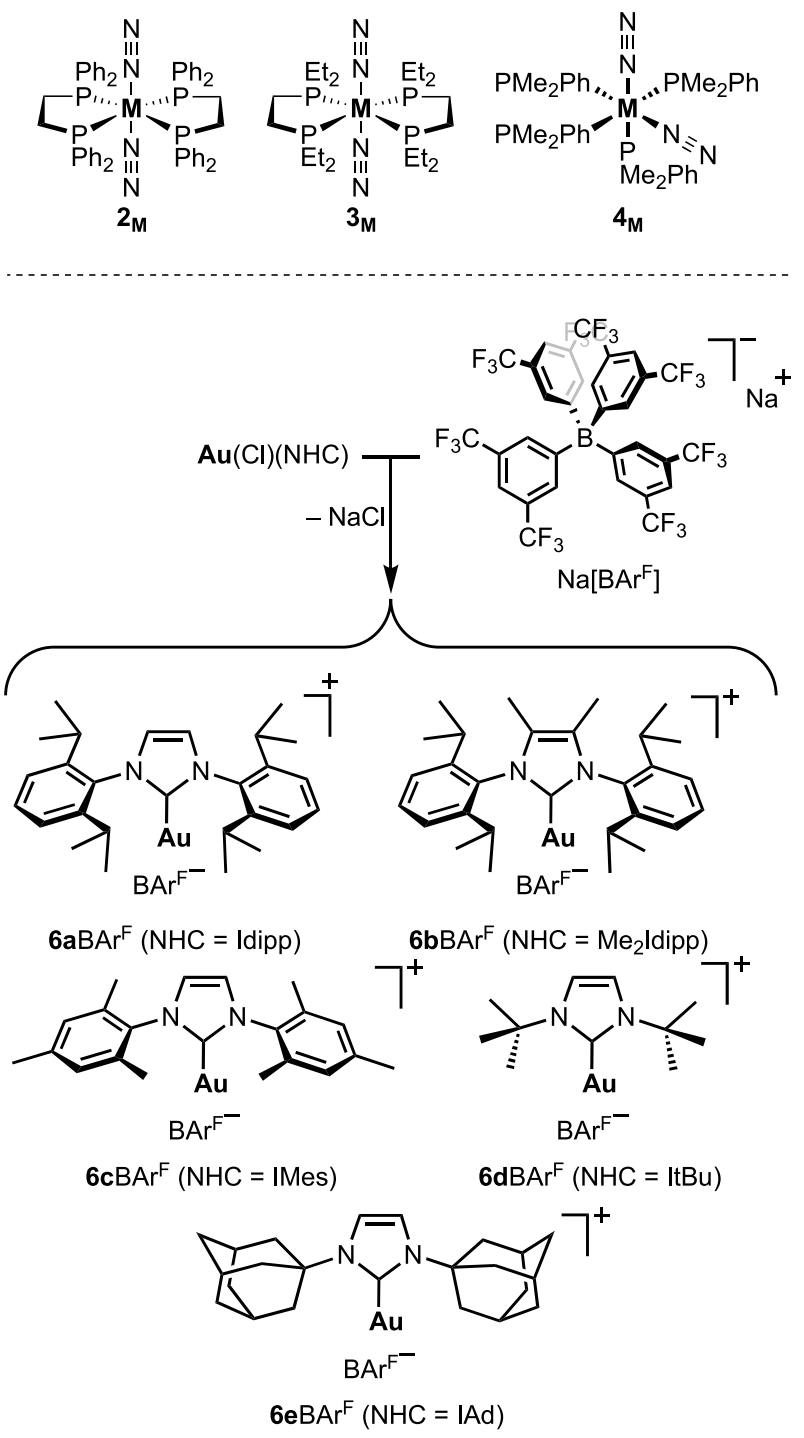

We first explored the reaction of the in situ generated [(Idipp)Au] $\left[\mathrm{BAr}^{\mathrm{F}}\right]\left(6 \mathrm{aBAr}^{\mathrm{F}}\right)$ with 1 equiv of trans-[Mo$\left.\left(\mathrm{N}_{2}\right)_{2}(\mathrm{dppe})_{2}\right] 2_{\mathrm{Mo}}$ at room temperature in chlorobenzene- $d_{5}$. Within a few minutes, a mixture of several compounds formed according to NMR spectroscopy. During the first hour of the reaction, the major product $(\approx 60 \%)$ was presumed to be the heterobimetallic adduct trans- $\left[\mathrm{Mo}\left(\mathrm{N}_{2}\right)(\mathrm{dppe})_{2}\left(\mu-\mathrm{N}_{2}\right) \mathrm{Au}-\right.$ (Idipp)][BAr $\left.{ }^{\mathrm{F}}\right], 7 \mathbf{a}_{\mathbf{M o}} \mathrm{BAr}^{\mathrm{F}}$. This complex was identified by a singlet in ${ }^{31} \mathrm{P}\left\{{ }^{1} \mathrm{H}\right\} \quad \mathrm{NMR}$ at $\delta 63.5 \mathrm{ppm}$, shifted upfield compared to $2_{\mathrm{Mo}}(\delta 65.7 \mathrm{ppm})$, and by two bands in IR spectroscopy at 1865 and $2127 \mathrm{~cm}^{-1}$ assignable to the elongated bridging $\mathrm{Mo}-\mathrm{N}_{2}-\mathrm{Au}$ moiety and the $\mathrm{N}_{2}$ in trans position, respectively (vs. $1974 \mathrm{~cm}^{-1}$ for $2_{\mathrm{Mo}}$ ). The mixture evolved rapidly, since after $3 \mathrm{~h}$ at $\mathrm{RT}, 7 \mathrm{a}_{\mathbf{M o}} \mathrm{BAr}^{\mathrm{F}}$ only amounted to $\approx 20 \%$ of the mixture and had disappeared after 
18 h. Decomposition of $7 \mathrm{a}_{\mathrm{Mo}} \mathrm{BAr}^{\mathrm{F}}$ occurred predominantly through the abstraction of a phosphine ligand by $6 \mathrm{a}^{+}$to yield the new complex [(dppe) $\operatorname{Mo}\left(\mu-\eta^{1}: \eta^{1}: \eta^{6}\right.$-dppe $) \operatorname{Au}($ Idipp $\left.)\right]$ $\left[\mathrm{BAr}^{\mathrm{F}}\right] \mathbf{8}_{\text {Mo }}(\approx 80 \%$; Figure 2$)$. Bright red single crystals fit

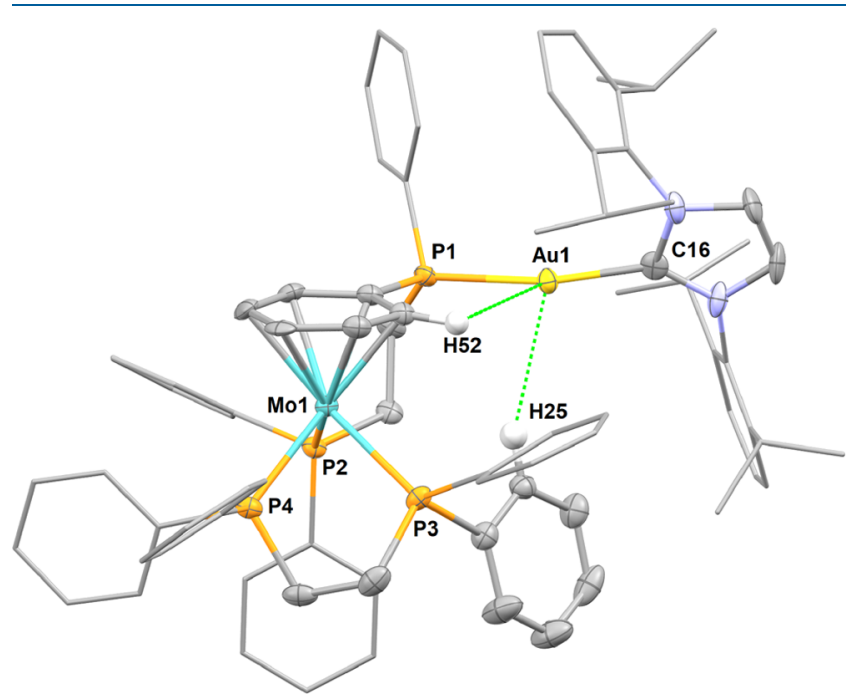

Figure 2. Molecular structure of complex $\mathbf{8}_{\mathrm{Mo}}$ in the solid state (ellipsoids are drawn at the $50 \%$ probability level, some ligand substituents are drawn with wireframe, all hydrogen atoms not interacting with the gold center and the $\mathrm{BAr}^{\mathrm{F}}$ anion are omitted for clarity). Selected distances $(\AA)$ and angles (deg): Mo1-P2 2.471(2), Mo1-P3 2.444(2), Mo1-P4 2.446(2), Au1-P1 2.283(2), Au1-C16 2.034(7), Au1-H25 2.881, Au1-H52 2.878, P1-Au1-C16 $169.5(2)$.

for X-ray diffraction analysis of $\mathbf{8}_{\mathrm{Mo}}$ could be recovered among polycrystalline materials upon slow diffusion of pentane into the crude mixture; however, efforts to isolate or recover single crystals of $7 \mathrm{a}_{\mathrm{Mo}} \mathrm{BAr}^{\mathrm{F}}$ were unsuccessful.

The Mo center adopts a three-legged piano stool geometry with a dppe unit coordinated classically with two phosphorus atoms and the other dppe unit chelating through one phosphorus atom and a phenyl substituent of the other phosphorus atom in a $\eta^{6}$ coordination mode. The second phosphorus is coordinated to the gold center of $6 \mathrm{a}$, which lies in a distorted linear geometry $\left(169.5^{\circ}\right)$ to accommodate for agostic interactions with hydrogen atoms of the Mo coordinated phenyl ring and a second phenyl substituent. NMR analysis of the mixture containing $\mathbf{8}_{\mathrm{Mo}}$ is coherent with the conservation of this structure in solution. The ${ }^{1} \mathrm{H}$ NMR spectrum shows a set of five protons at $\delta 3.26,3.49,3.73,4.58$, and $4.63 \mathrm{ppm}$ diagnostic of an $\eta^{6}$-phenyl on the Mo center, in line with the chemical shifts of $\eta^{6}$-phenylphosphine ligands found on comparable Mo complexes. ${ }^{40}$ The agostic interaction between the gold center and the two ortho protons of one phenyl substituent is corroborated by a particularly upfield signal at $5.46 \mathrm{ppm}$ in ${ }^{1} \mathrm{H}$ NMR. All phosphine ligands are inequivalent: in ${ }^{31} \mathrm{P}\left\{{ }^{1} \mathrm{H}\right\} \mathrm{NMR}$, three resonances show coupling to each other at $\delta=76.6,75.1$, and $41.9 \mathrm{ppm}$, the fourth signal for the phosphine coordinated to the gold cation being found at $\delta 26.7 \mathrm{ppm}$.

Attempts to produce crystals of $7 \mathrm{a}_{\mathrm{Mo}} \mathrm{BAr}{ }^{\mathrm{F}}$ and $\mathbf{8}_{\mathrm{Mo}}$ led on some occasions to the formation of minute amounts of dark yellow crystals identified by X-ray diffraction analysis as $\left[\mathrm{Mo}(\mathrm{Cl})\left(\mathrm{N}_{2}\right)(\mathrm{dppe})_{2}\right]\left(\mathbf{9}_{\mathrm{Mo}}\right.$, Figure 3$)$. The $\mathrm{Mo}^{\mathrm{I}}$ center in $\mathbf{9}_{\mathrm{Mo}}$ is stabilized by a chloride ligand presumably sourced from the

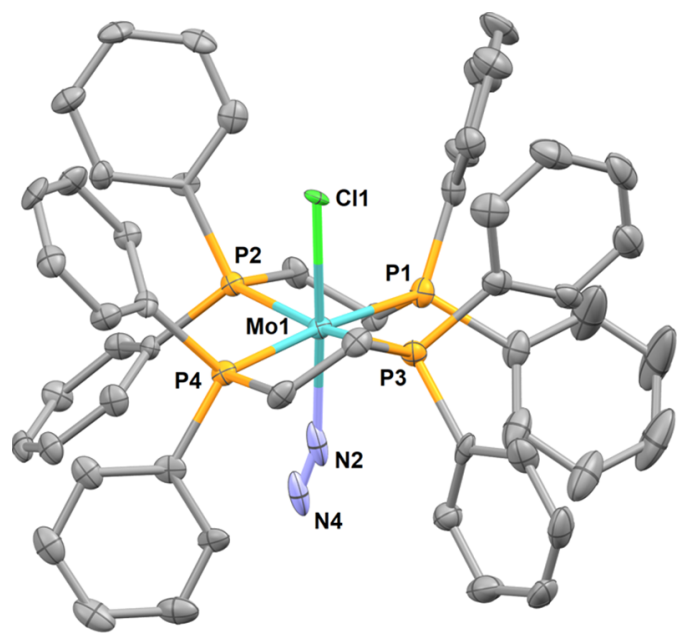

Figure 3. Molecular structure of complex $\mathbf{9}_{\mathrm{Mo}}$ in the solid state (ellipsoids are drawn at the $50 \%$ probability level, hydrogen atoms are omitted for clarity). Selected bond lengths $(\AA)$ and angles (deg): Mo1-Cl1 2.396(7), Mo1-N2 2.15(5), P1-Mo1 2.4796(19), P2Mo1 2.5083(18), P3-Mo1 2.4622(19), P4-Mo1 2.5032(18), Cl1$\mathrm{W}-\mathrm{N} 2$ 177.1(12).

$\mathrm{NaCl}$ formed by salt metathesis between $\mathrm{NaBAr}^{\mathrm{F}}$ and $[\mathrm{Au}(\mathrm{Cl})(\mathrm{Idipp})]$. $\mathbf{9}_{\text {Mo }}$ has an octahedral geometry with dinitrogen and chloride ligands in a trans position, both statistically disordered within the crystal lattice. ${ }^{41}$ The formation of $\mathrm{Mo}^{\mathrm{I}}$ species can reasonably be attributed to electronic transfers between $\mathrm{Mo}^{0}$ and $\mathrm{Au}^{\mathrm{I}}$ even though the nature of the accompanying $\mathrm{Au}^{0}$ species has not been determined.

Reaction of trans- $\left[\mathrm{W}\left(\mathrm{N}_{2}\right)_{2}(\mathrm{dppe})_{2}\right]\left(2_{\mathrm{W}}\right)$ with $6 \mathrm{aBAr}{ }^{\mathrm{F}}$ and $\left[\mathrm{Au}\left(\mathrm{Me}_{2} \mathrm{Idipp}\right)\right]\left[\mathrm{BAr}^{\mathrm{F}}\right]\left(6 \mathrm{bBAr}^{\mathrm{F}}, \mathrm{Me}_{2} \mathrm{Idipp}: 1,3-\mathrm{bis}[2,6-\mathrm{bis}(1-\right.$ methylethyl)phenyl]-1,3-dihydro-4,5-dimethyl-2H-imidazol-2ylidene) produced very similar results, which is unsurprising given the structural closeness between the two NHC ligands. $2_{\mathrm{W}}$ was reacted with 1 equiv of $6 \mathrm{aBAr} \mathrm{r}^{\mathrm{F}}$ or $6 \mathrm{bBAr}^{\mathrm{F}}$ at room temperature in chlorobenzene- $d_{5}$. Analyses of the reaction mixtures by NMR and IR spectroscopies were indicative of the immediate formation of the heterobimetallic adducts $\left[\mathrm{W}\left(\mathrm{N}_{2}\right)\right.$ (dppe $)_{2}\left(\mu-\mathrm{N}_{2}\right) \mathrm{Au}($ Idipp $\left.)\right]\left[\mathrm{BAr}^{\mathrm{F}}\right] \quad\left(7 \mathrm{a}_{\mathrm{W}} \mathrm{BAr}^{\mathrm{F}}\right)$ and $\left[\mathrm{W}\left(\mathrm{N}_{2}\right)\right.$ (dppe) $\left.{ }_{2}\left(\mu-\mathrm{N}_{2}\right) \mathrm{Au}\left(\mathrm{Me}_{2} \mathrm{Idipp}\right)\right]\left[\mathrm{BAr}^{\mathrm{F}}\right]\left(7 \mathbf{b}_{\mathrm{W}} \mathrm{BAr}^{\mathrm{F}}\right.$; Scheme 4$)$. The ${ }^{31} \mathrm{P}\left\{{ }^{1} \mathrm{H}\right\}$ NMR spectra of the adducts display a single peak shifted upfield compared to $2_{\mathrm{W}}(\delta=46.2 \mathrm{ppm})$ at $45.5 \mathrm{ppm}$ $\left(J_{\mathrm{PW}}=320.3 \mathrm{~Hz}, 7 \mathrm{a}_{\mathrm{W}} \mathrm{BAr}^{\mathrm{F}}\right)$ or $46.2 \mathrm{ppm}\left(J_{\mathrm{PW}}=307.4 \mathrm{~Hz}\right.$, $\left.7 b_{\mathrm{W}} \mathrm{BAr}{ }^{\mathrm{F}}\right)$. The ${ }^{1} \mathrm{H}$ NMR spectrum showed two inequivalent

Scheme 4. Synthesis and Proposed Identity of $7 a_{W} B A r^{F}$ and $7 \mathbf{b}_{\mathrm{W}} \mathrm{BAr}{ }^{\mathrm{F}}$

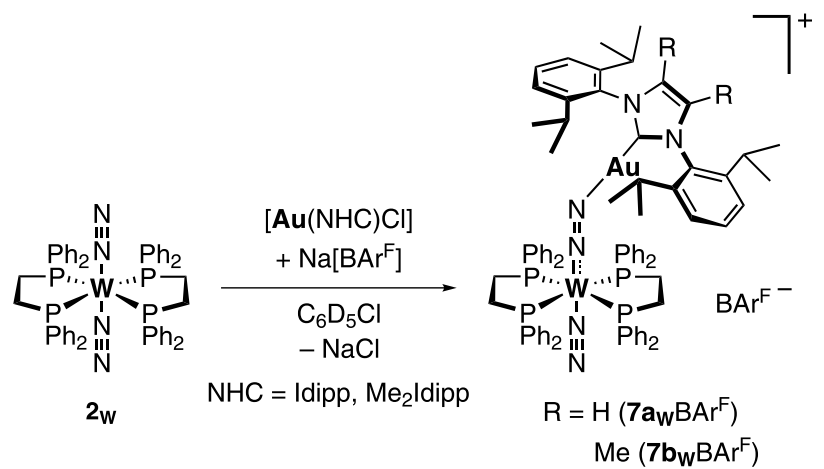


sets of methylene protons indicating a decreased symmetry at the $\mathrm{W}$ center. There is a single set of signals for the NHCs, and $7 a_{W} B^{B}{ }^{F}$ presents a slight downfield shift for the protons of the backbone of the imidazole fragment. This was attributed to a decrease of electronic density due to the delocalization of the $\pi$-electrons toward the more acidic gold center. This increased acidity is also corroborated by the significant upfield shift of the carbenic carbons in ${ }^{13} \mathrm{C}$ NMR at $166.6 \mathrm{ppm}\left(7 \mathrm{a}_{\mathrm{W}} \mathrm{BAr}{ }^{\mathrm{F}}\right)$ and $162.5 \mathrm{ppm}\left(7 \mathrm{~b}_{\mathrm{W}} \mathrm{BAr}{ }^{\mathrm{F}}\right)$ vs 176.8 and $172.8 \mathrm{ppm}$ for the corresponding $[\mathrm{Au}(\mathrm{Cl})(\mathrm{NHC})]$ complexes. The ${ }^{13} \mathrm{C}$ NMR carbenic carbon chemical shift of $7 \mathrm{a}_{\mathrm{W}} \mathrm{BAr}^{\mathrm{F}}$ is comparable to that of isolated acetonitrile adducts of $[\mathrm{Au}(\mathrm{NCMe})(\text { Idipp })]^{+}$ salts. ${ }^{42}$ The spectral signatures in ${ }^{11} \mathrm{~B}$ and ${ }^{19} \mathrm{~F}$ NMR are typical of the $\mathrm{BAr}^{\mathrm{F}}$ anion.

Adducts $7 a_{W} B A r^{F}$ and $7 b_{W} B A r^{F}$ retain both $N_{2}$ ligands in solution according to infrared measurements in chlorobenzene that showed two broad, intense bands at 1851 and $2085 \mathrm{~cm}^{-1}$ assignable to the elongated bridging $\mathrm{W}-\mathrm{N}_{2}-\mathrm{Au}$ moiety and the mono ligated $\mathrm{N}_{2}$, respectively (vs. $1947 \mathrm{~cm}^{-1}$ for $2_{\mathrm{W}}$ in $\mathrm{PhCl}$ ). The shift to higher wavenumbers in the IR spectra (vs. $2_{\mathrm{W}}$ ) of the $\mathrm{N}_{2}$ in trans position is diagnostic of decreased $\mathrm{N}_{2}$ activation. Accordingly, $7 a_{w} B A r^{F}$ and $7 b_{w} B A r^{F}$ are unreactive toward a second equivalent of $[\mathrm{Au}(\mathrm{NHC})]^{+}$. After in situ formation in chlorobenzene- $d_{5}$, the adducts are stable for hours, but $2_{\mathrm{W}}$ is slowly recovered over a period of days. Attempts to remove the solvent under a vacuum or to precipitate $7 a_{W} B A r^{F}$ and $7 b_{w} B A r^{F}$ by treatment of the solution with pentane or hexamethyldisiloxane yielded predominantly $2_{\mathrm{W}}(>50 \%)$ as well as multiple uncharacterized $\mathrm{W}$ complexes and several sets of signals for the NHC moieties are observed in ${ }^{1} \mathrm{H}$ NMR. The instability of $7 \mathbf{a}_{\mathrm{w}} \mathrm{BAr}{ }^{\mathrm{F}}$ and $7 \mathbf{b}_{\mathrm{w}} \mathrm{BAr}{ }^{\mathrm{F}}$ generated in this manner precluded their isolation and characterization by X-ray diffraction techniques. Recovery of $\mathbf{2}_{\mathrm{Mo}} / \mathbf{2}_{\mathrm{W}}$ from adducts $7 \mathrm{a}_{\mathrm{W}} \mathrm{BAr}{ }^{\mathrm{F}}$ and $7 \mathbf{b}_{\mathrm{W}} \mathrm{BAr}{ }^{\mathrm{F}}$ suggests that the free gold cations are in equilibrium with the gold cations coordinated to the $\mathrm{N}_{2}$ complex. The inherent instability of monoligated gold cations in solution might then result in their decomposition. These equilibria are evidenced by the presence of a small band corresponding to the $\mathrm{N}_{2}$ ligands of $\mathbf{2}_{\mathrm{Mo}} / \mathbf{2}_{\mathrm{W}}$ in the infrared measurement of the adducts in chlorobenzene $\left(1947 \mathrm{~cm}^{-1}\right.$ for $\left.2_{\mathrm{W}}\right)$. There is no interaction between $2_{\mathrm{W}}$ and $6 \mathrm{a}^{+}$in THF- $d_{8}$, the latter forming the THF adduct [Au(THF)(Idipp) $]^{+}$already reported in the literature. ${ }^{42}$ The weak gold coordination to $\mathrm{N}_{2}$ in $7 \mathrm{a}_{\mathrm{W}} \mathrm{BAr} \mathrm{r}^{\mathrm{F}}$ and $7 \mathbf{b}_{\mathrm{W}} \mathrm{BAr}{ }^{\mathrm{F}}$ could stem from the steric bulk of both the gold NHCs and the $\mathrm{N}_{2}$ complexes' phosphine ligands.

We then explored the formation of adducts with [Au(IMes) $]^{+}\left(6 \mathrm{c}^{+}\right.$, IMes: 1,3-bis (2,4,6-trimethylphenyl)imidazol2-ylidene $)$ and $\left[\mathrm{Au}\left(\mathrm{I}^{t} \mathrm{Bu}\right)\right]^{+}\left(6 \mathrm{~d}^{+}, \mathrm{I}^{t} \mathrm{Bu}\right.$ : 1,3-ditert-butylimidazol-2-ylidene) that present a reduced steric hindrance at the gold center (vs. $6 \mathbf{a}^{+}$and $6 \mathbf{b}^{+}$). $\mathbf{2}_{\text {Mo }}$ reacted with $6 \mathrm{cBAr}^{\mathrm{F}}$ or $6 \mathrm{dBAr}^{\mathrm{F}}$ in chlorobenzene- $d_{5}$ at RT to yield complex mixtures upon solvation of the gold cations. The main products visible within the first hour ( $>60 \%$ in both cases) showed spectroscopic signatures similar to $\mathbf{8}_{\mathrm{Mo}}$, diagnostic of $\eta^{6}$-phenyl coordination to the Mo center with a set of five broad signals in ${ }^{1} \mathrm{H}$ NMR (Figures S67 and S69). Phosphine coordination to the gold centers is characterized by signals in ${ }^{31} \mathrm{P}\left\{{ }^{1} \mathrm{H}\right\} \mathrm{NMR}$ at $\delta=29.8$ and $29.3 \mathrm{ppm}$ for $\mathbf{6} \mathrm{c}^{+}$and $\mathbf{6} \mathbf{d}^{+}$, respectively. The lower steric hindrance at the gold center seemingly favors abstraction of the phosphine ligand as no putative $\mathrm{N}_{2}$ adduct could be observed, contrary to the reaction of $2_{\mathrm{Mo}}$ with $6 \mathrm{aBAr}$. The reaction of $2 \mathrm{w}$ with 1 equiv of $6 \mathrm{cBAr}^{\mathrm{F}}$ or $6 \mathrm{dBAr}^{\mathrm{F}}$ in chlorobenzene- $d_{5}$ at RT allowed immediate observation of the putative adducts $\left[\mathrm{W}\left(\mathrm{N}_{2}\right)(\mathrm{dppe})_{2}\left(\mu-\mathrm{N}_{2}\right) \mathrm{Au}(\mathrm{NHC})\right]\left[\mathrm{BAr}{ }^{\mathrm{F}}\right]$ characterized by singlets in ${ }^{31} \mathrm{P}\left\{{ }^{1} \mathrm{H}\right\} \mathrm{NMR}$ at $\delta=44.4$ and 45.8 ppm for $7 c_{W} B A r^{F}$ and $7 d_{w} B A r^{F}$, respectively, that are upfieldshifted compared to $2_{\mathrm{W}}(\delta 46.2 \mathrm{ppm})$. Infrared analysis of aliquots taken immediately after the mixing of $2_{\mathrm{W}}$ and $6 \mathrm{cBAr}{ }^{\mathrm{F}}$ (or $6 \mathrm{dBAr}^{\mathrm{F}}$ ) in chlorobenzene also supports adduct formation with the presence of two vibrations at $1865 \mathrm{~cm}^{-1}\left(7 \mathrm{~d}_{\mathrm{W}} \mathrm{BAr}^{\mathrm{F}}\right.$ : $\left.1855 \mathrm{~cm}^{-1}\right)$ and $2077 \mathrm{~cm}^{-1}\left(7 \mathrm{~d}_{\mathrm{W}} \mathrm{BAr}^{\mathrm{F}}: 2077 \mathrm{~cm}^{-1}\right)$ corresponding to the bridging $\mathrm{W}-\mathrm{N}_{2}-\mathrm{Au}$ moiety and the $\mathrm{N}_{2}$ in trans relationship, respectively (vs $1947 \mathrm{~cm}^{-1}$ for $2_{\mathrm{W}}$ in $\mathrm{PhCl}$ ). These adducts are short-lived, as they represented approximatively $60 \%$ of the mixture after $30 \mathrm{~min}$ at room temperature and had completely decomposed after $4 \mathrm{~h}$ to yield an intractable mixture of paramagnetic compounds and complexes issued from phosphine abstractions. Due to their instability, these putative adducts could not be further characterized or isolated. As $\mathbf{2}_{\mathrm{W}}$ is not recovered, their decomposition process stands in contrast with the decomposition of $7 a_{W} B A r^{F}$ and $7 b_{W} B A r^{F}$. This can be rationalized by a stronger gold coordination to the dinitrogen ligand owing to the reduced steric strain, which is however balanced by an increased aptitude to engage in phosphine abstraction reaction (presumably driven by steric relief at the $\mathrm{W}$ center). The formation of paramagnetic complexes as testified to by broad signals in ${ }^{1} \mathrm{H}$ NMR could also be favored by the reduced steric congestion, offering easier pathways for electronic transfers to take place (vs $7 a_{\mathrm{W}} \mathrm{BAr}^{\mathrm{F}}$ and $7 \mathbf{b}_{\mathrm{W}} \mathrm{BAr}{ }^{\mathrm{F}}$ ).

To assess the influence of the steric congestion of the $\mathrm{N}_{2}$ complex, we explored the coordination of $6 \mathrm{a}^{+}$to complexes $\left[\mathrm{M}\left(\mathrm{PMe} \mathrm{Ph}_{2}\right)_{4}\left(\mathrm{~N}_{2}\right)_{2}\right] \quad\left(4_{\mathrm{M}}\right)$, which offer reduced steric hindrance and increased flexibility of the ligand spheres compared to the dppe complexes. We reacted a cis/trans mixture of $\left[\mathrm{Mo}\left(\mathrm{N}_{2}\right)_{2}\left(\mathrm{PMe}_{2} \mathrm{Ph}\right)_{4}\right]\left(4_{\mathrm{Mo}}\right)$ with 1 equiv of $6 \mathrm{aBAr}{ }^{\mathrm{F}}$ in chlorobenzene- $d_{5}$ at room temperature, and we observed that the orange solution rapidly turned dark red upon solvation of the gold salt. The heteroleptic complex [Au$\left.(\mathrm{Idipp})\left(\mathrm{PMe}_{2} \mathrm{Ph}\right)\right]\left[\mathrm{BAr}^{\mathrm{F}}\right]$ was obtained quantitatively within minutes, characterized by a signal at $\delta 11.5 \mathrm{ppm}$ in ${ }^{31} \mathrm{P}\left\{{ }^{1} \mathrm{H}\right\}$ NMR spectroscopy (Scheme 5) and identified by its isolation

Scheme 5. Phosphine abstraction on $4_{\mathrm{Mo}}$ to form $\left[\mathrm{Au}(\mathrm{Idipp})\left(\mathrm{PMe}_{2} \mathrm{Ph}\right)\right]\left[\mathrm{BAr}^{\mathrm{F}}\right]$

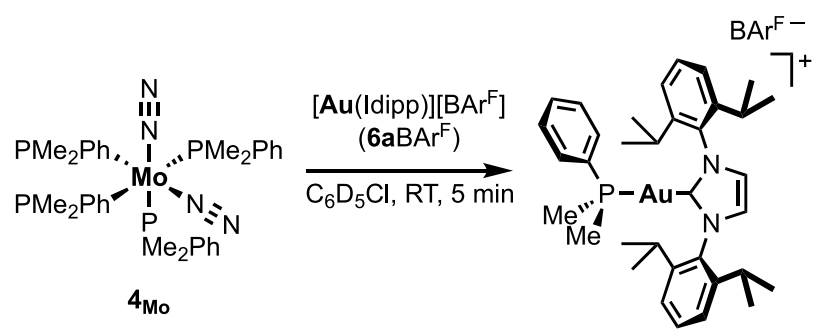

from the reaction mixture (see SI). Under the same conditions as with cis- $\left[\mathrm{Mo}\left(\mathrm{N}_{2}\right)_{2}\left(\mathrm{PMe}_{2} \mathrm{Ph}\right)_{4}\right] \quad\left(4_{\mathrm{Mo}}\right)$, the phosphine abstraction on cis- $\left[\mathrm{W}\left(\mathrm{N}_{2}\right)_{2}\left(\mathrm{PMe}_{2} \mathrm{Ph}\right)_{4}\right]\left(\mathbf{4}_{\mathrm{W}}\right)$ by $\mathbf{6 a}^{+}$proceeded at a much slower rate, allowing for $6 \mathrm{a}^{+}$to engage in electron transfer reactions with the thus-formed unsaturated $\mathrm{W}$ complex, producing uncharacterized paramagnetic compounds.

The facile abstraction of the monodentate phosphine highlighted the need to use chelating phosphine ligands able to limit phosphine abstraction while presenting a reduced steric profile compared to dppe. To this end, we then explored 
the coordination of gold cations to $3_{\mathrm{w}}$. The depe ligand presents the double advantage of being less encumbered and more electron donating than dppe. The reduced steric bulk should allow for a closer proximity of the gold center to the $\mathrm{N}_{2}$ ligand and prevent phosphine abstraction by mitigating the steric relief driving force. The increased electron donating ability of depe also provides stronger phosphine metal bonds, although an increased electronic density at the metal center should also favor electron transfer reactions. In chlorobenzene$d_{5}$ at RT, $3_{\mathrm{w}}$ reacted immediately with 1 equiv of $6 \mathbf{b}^{+}, \mathbf{6 c ^ { + } ,} 6 \mathrm{~d}^{+}$, and $6 \mathrm{e}^{+}$to form the corresponding heterobimetallic adducts $\left[\mathrm{W}\left(\mathrm{N}_{2}\right)(\text { depe })_{2}\left(\mu-\mathrm{N}_{2}\right) \mathrm{Au}(\mathrm{NHC})\right]\left[\mathrm{BAr}{ }^{\mathrm{F}}\right] \mathbf{1 0 b}-\mathbf{e}_{\mathrm{W}} \mathrm{BAr}^{\mathrm{F}}$ as the main product, along with minor, unidentified paramagnetic compounds. Under the same conditions, the reaction of $6 \mathrm{aBAr}{ }^{\mathrm{F}}$ with $3_{\mathrm{W}}$ immediately gave an intractable mixture of products. The reactivity difference between $6 a^{+}$and $6 b^{+}$could originate from the electron donation of the methyl groups to the imidazole ring of $\mathbf{6 b}^{+}$, the resulting increased electronic density at the gold center in turn disfavoring electronic transfers from the $\mathrm{W}$ center. Adducts $\mathbf{1 0 b}-\mathbf{e}_{\mathrm{W}} \mathrm{BAr}{ }^{\mathrm{F}}$ share similar spectroscopic signatures of which key parameters are summarized in Table 1 . In ${ }^{1} \mathrm{H} N M R$, adducts $\mathbf{1 0 b}-\mathbf{d}_{\mathrm{W}} \mathrm{BAr}{ }^{\mathrm{F}}$ are

Table 1. Key NMR Chemical Shifts and Vibrational Modes of Adducts $10 b-e_{W} B A r^{F}$ in Solution

$\begin{array}{ccccc}\text { complex } & \delta{ }^{31} \mathrm{P}^{a} & \Delta \delta{ }^{31} \mathrm{P} \text { vs } \mathbf{3}_{\mathrm{W}}{ }^{a} & \nu_{\mathrm{NN}}{ }^{b} & \Delta \nu_{\mathrm{NN}} \text { vs } \mathbf{3}_{\mathrm{W}}{ }^{b} \\ \mathbf{1 0 b}_{\mathrm{W}} \mathrm{BAr}^{\mathrm{F}} & 34.2 & -2.0 & 1796 & -113 \\ & & & 2044 & +135 \\ \mathbf{1 0}_{\mathrm{W}} \mathrm{BAr}^{\mathrm{F}} & 34.4 & -1.8 & 1775 & -134 \\ & & & 2050 & +141 \\ \mathbf{1 0 d}_{\mathrm{W}} \mathrm{BAr}^{\mathrm{F}} & 32.6 & -3.6 & 1767 & -142 \\ & & & 2052 & +143 \\ \mathbf{1 0}_{\mathrm{W}} \mathrm{BAr}^{\mathrm{F}} & 34.6 & -1.6 & 1783 & -126 \\ & & & 2048 & +139\end{array}$

${ }^{a} \mathrm{C}_{6} \mathrm{D}_{5} \mathrm{Cl}$, expressed in ppm. ${ }^{b} \mathrm{C}_{6} \mathrm{H}_{5} \mathrm{Cl}$ solution in transmission cell, expressed in $\mathrm{cm}^{-1}$.

characterized by a single set of signals for the NHC ligand along with inequivalent methylene and ethyl fragments, indicative of a loss of symmetry at the $\mathrm{W}$ center. On the contrary, the NHC ligand of $\mathbf{1 0 e}_{\mathrm{W}} \mathrm{BAr}^{\mathrm{F}}$ shows differentiated signals in ${ }^{1} \mathrm{H}$ NMR for the substituents and the imidazole ring, which could be related to steric interactions between the depe ligand and the adamantyl moieties hindering free rotation on the NMR time scale. In all adducts, the phosphine ligands display a single, well resolved peak in ${ }^{31} \mathrm{P}\left\{{ }^{1} \mathrm{H}\right\} \mathrm{NMR}$, shifted upfield compared to $3_{\mathrm{W}}(\Delta \delta:-1.6$ to $-3.6 \mathrm{ppm})$. As with adducts of dppe-supported complexes, the solution IR spectra of $10 b-e_{W} B A r^{F}$ display two broad bands corresponding to the elongated bridging dinitrogen in the $1700-1800 \mathrm{~cm}^{-1}$ region and the trans dinitrogen ligand in the $2000-2100 \mathrm{~cm}^{-1}$ region.

Isolation of Heterobimetallic Complexes 10b$\mathbf{e}_{\mathrm{W}} \mathrm{BAr} \mathbf{r}^{\mathrm{F}}$. Complexes $\mathbf{1 0 b}-\mathbf{e}_{\mathrm{W}} \mathrm{BAr}{ }^{\mathrm{F}}$ decomposed within hours in solution as evidenced by the formation of broad signals along with multiples set of signals for the NHC ligands in ${ }^{1} \mathrm{H}$ $\mathrm{NMR}$ and the disappearance of ${ }^{31} \mathrm{P}$ NMR signals, both diagnostics of the formation of paramagnetic compounds (vide infra), presumably formed by $\mathrm{W}(0) \rightarrow \mathrm{Au}(\mathrm{I})$ electronic transfers. Nevertheless, $\mathbf{1 0 b}-\mathbf{e}_{\mathrm{W}} \mathrm{BAr}{ }^{\mathrm{F}}$ can be precipitated by pouring concentrated $\mathrm{PhF}$ solutions of the freshly formed adducts in precooled pentane $\left(-40{ }^{\circ} \mathrm{C}\right)$ to afford purple to dark brown $\mathrm{NaCl} / \mathbf{1 0 b}-\mathbf{e}_{\mathrm{W}} \mathrm{BAr}^{\mathrm{F}}$ mixtures, recovered by decantation. The fine $\mathrm{NaCl}$ precipitate can then be suspended with pentane washes of the solids, allowing for the isolation of $\mathbf{1 0 b}-\mathbf{e}_{\mathrm{W}} \mathrm{BAr}{ }^{\mathrm{F}}$ as purple or brown microcrystalline powders in good yields (80-85\%; Scheme 6). The isolated adducts

Scheme 6. Isolation of Heterobimetallic Complexes 10b$\mathrm{e}_{\mathrm{W}} \mathrm{BAr}^{\mathrm{F}}$ with Relevant Vibrational Modes (ATR)
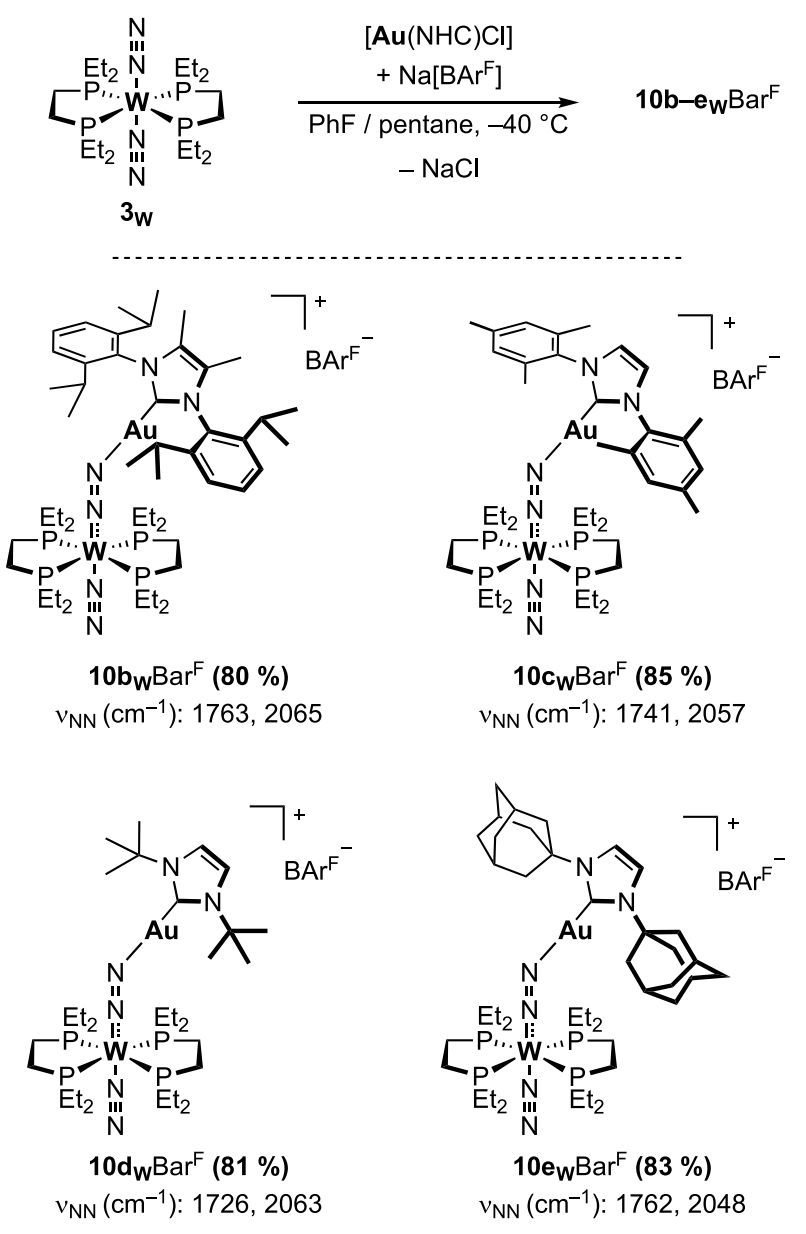

decompose slowly at room temperature and rapidly under a vacuum but can be stored indefinitely at $-40{ }^{\circ} \mathrm{C}$. Characterization by elemental analysis gave a lower-than-expected $\mathrm{N}$ content; however, this is likely the result of degradation during the analytical process as FTIR-ATR analysis confirmed the retention of the second $\mathrm{N}_{2}$ ligand in the solid state.

The bridging dinitrogen ligand is moderately activated in complexes $\mathbf{1 0 b}-\mathbf{e}_{\mathrm{W}} \mathrm{BAr} \mathrm{r}^{\mathrm{F}}$ as evidenced by shifts in the vibrational frequencies ranging from -123 to $-160 \mathrm{~cm}^{-1}$ (vs $3_{\mathrm{W}}$ ). Evaluation of the Lewis acidity of cations $6 \mathrm{a}^{+}$to $6 \mathrm{e}^{+}$ yielded similar acceptor numbers (from $6 \mathbf{a}^{+}$to $6 \mathrm{e}^{+}$, ANs = 87.3, 86.4, 87.5, 85.6, 85.3, see Table S2) for all NHC ligands, revealing that the variations of $\mathrm{N}_{2}$ activation were mostly due to sterics. The percent buried volume $\left(\% V_{\text {bur }}\right)$ is a good indication of the steric hindrance in the proximity of the gold center for symmetrical NHC ligands. According to the measured $\% V_{\text {bur }}$ on a series of $[\mathrm{Au}(\mathrm{Cl})(\mathrm{NHC})]$ complexes, cations $6^{+}$can be ordered as $\mathbf{6} \mathrm{d}^{+}<6 \mathrm{e}^{+} \approx \mathbf{6} \mathrm{c}^{+}<\mathbf{6 b}^{+}$by increasing steric hindrance $\left(\% V_{\text {bur }}=44.4,36.5,39.8\right.$, and $39.6 \%$ from $6 \mathbf{b}^{+}$to $6 \mathbf{e}^{+}$, respectively). ${ }^{43}$ However, the highest $\mu-\mathrm{N}_{2}$ ligand activation is achieved in the adduct ${ }^{10 d_{W}} \mathrm{BAr}^{\mathrm{F}}$ and differs significantly from adduct $\mathbf{1 0}_{\mathrm{W}} \mathrm{BAr}^{\mathrm{F}}$, which indicates 
that long-range steric hindrance has more impact than that in the gold center proximity. Indeed, the bulky, far-reaching adamantyl and diisopropylphenyl substituents of $6 \mathrm{e}^{+}$and $6 \mathbf{b}^{+}$ translate to lower $\mathrm{N}_{2}$ activation than when the planar mesityl or the smaller tert-butyl substituents found in $6 c^{+}$or $\mathbf{6 d}^{+}$, respectively, are present. No correlations were found between $\Delta \nu_{\mathrm{NN}}$ and either the ANs of the cations or the $\% V_{\text {bur }}$

The structure of $\mathbf{1 0 e}_{\mathrm{W}} \mathrm{BAr}{ }^{\mathrm{F}}$ could be determined by single crystal X-ray diffraction analysis. This is, to the best of our knowledge, the first structural characterization of an $\mathrm{N}_{2}$ bridged heterobimetallic complex featuring a group 11 metal. It features an octahedral ligand sphere around the $\mathrm{W}$ center with two depe ligands included almost perfectly in the equatorial plan (Figure 4). The $\mathrm{N}_{2}$ and $\mu-\mathrm{N}_{2}$ ligands are in an axial

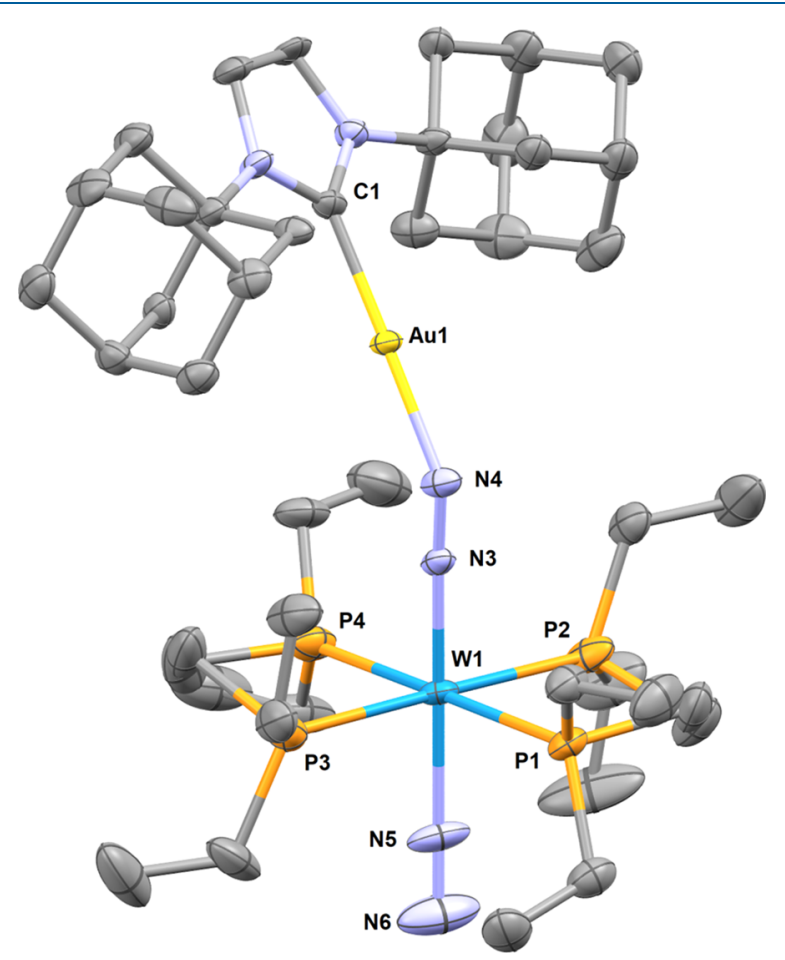

Figure 4. Molecular structure of complex $10 \mathrm{e}_{\mathrm{W}} \mathrm{BAr}^{\mathrm{F}}$ in the solid state (ellipsoids are drawn at the 50\% probability level, hydrogen atoms are omitted for clarity). Selected bond lengths $(\AA)$ and angles (deg): W1-N4 1.896(6), N4-N3 1.179(8), N3-Au1 2.015(6), W1-N5 2.071(7), N5-N6 1.09(1), W1-N4-N3 176.3(5), N4-N3-Au1 142.6(5), W1-N5-N6 177.4(7), N4-W1-N5 178.2(3), C1-Au1N3 179.2(3).

position with a slight deformation to accommodate for the coordination of $[\mathrm{Au}(\mathrm{IAd})]^{+}\left(\mathrm{N}-\mathrm{W}-\mathrm{N}=178.2(3)^{\circ}\right)$. The $\mathrm{W}\left(\mu-\mathrm{N}_{2}\right)(\mathrm{Au}\{\mathrm{NHC}\})$ motif presents a shortened $\mathrm{W}-\mathrm{N}$ bond $\left(1.896 \AA\right.$ vs $2.0154(11) \AA$ for $\left.3_{\mathrm{W}}\right)$ and a lengthened $\mathrm{N}-\mathrm{N}$ bond $\left(1.179 \AA\right.$ vs $1.096 \AA$ for free $\mathrm{N}_{2}$ and $1.123(2) \AA$ for $\left.3_{\mathrm{W}}\right)$. The bond orders are ambiguous with a $\mathrm{W}-\mathrm{N}$ distance falling within simple and double bonds and the $\mathrm{N}-\mathrm{N}$ distance within double and triple bonds. ${ }^{44}$ The gold(I) complex unsurprisingly shows linear geometry with a N-Au bond distance of $2.015 \AA$, matching with the few examples of $[\mathrm{Au}(\mathrm{NHC})]^{+}$coordination to nitrogen bases (e.g., $2.016 \AA$ for $[(\mathrm{MeCN}) \mathrm{Au}(\mathrm{Idipp} *)]$ $\left.\left[\mathrm{BF}_{4}\right]\right)$ with structural characterization. ${ }^{45}$ The $\mathrm{N}-\mathrm{N}-\mathrm{Au}$ angle of $142.6^{\circ}$ suggests a similar bonding situation as the one found in main group adducts of end-on dinitrogen complexes. ${ }^{11 e, 12,46}$
Comparison with Relevant $\mathrm{N}_{2}$-Bridged Adducts. To the best of our knowledge, there is only one example of a group $6 \mathrm{~N}_{2}$ complex reacting with a Lewis acidic, d-block metal compound in the literature, to lead to the $\mathrm{Mo}(0) / \mathrm{Fe}(\mathrm{II})$ heterobimetallic complex $\left[(\right.$ toluene $)\left(\mathrm{PPh}_{3}\right)_{2} \mathrm{Mo}\left(\mu-\mathrm{N}_{2}\right) \mathrm{Fe}$ $(\mathrm{Cp})(\mathrm{dmpe})]\left[\mathrm{BF}_{4}\right]$ (dmpe $=1,2$-bis (dimethylphosphino)ethane). ${ }^{47}$ Its structure is however very similar to the numerous LA-TMs adducts reported with the $\mathrm{d}^{6}$ trans$\left[\operatorname{ReCl}\left(\mathrm{N}_{2}\right)\left(\mathrm{PMe}_{2} \mathrm{Ph}\right)_{4}\right]^{6}$ complex, and they contrast strikingly with the $[\mathrm{Au}(\mathrm{NHC})]^{+}$adducts of $2_{\mathrm{W}}$ and $3 \mathrm{w}$. In typical adducts with a Lewis acidic metal $\mathrm{M}^{\prime}$, the $\mathrm{M}-\left(\mu-\mathrm{N}_{2}\right)-\mathrm{M}^{\prime}$ core is essentially linear owing to the implication of empty or partially filled $\mathrm{d}$ orbitals of $\mathrm{M}^{\prime}$ in a four-center $\pi$ molecular orbital. ${ }^{48}$ Conversely, the structure of $\mathbf{1 0 e}_{\mathrm{W}} \mathrm{BAr}{ }^{\mathrm{F}}$ has a bent $\mathrm{W}-\left(\mu-\mathrm{N}_{2}\right)-\mathrm{Au}$ motif. Since this bonding situation is typically found with main group Lewis acids, ${ }^{12}$ comparison of $[\mathrm{Au}(\mathrm{NHC})]^{+}$coordination to $\mathrm{N}_{2}$ with boranes such as $\mathbf{1}$ is especially relevant. To this end, we have carried out the reaction of trans- $\left[\mathrm{M}(\text { depe })_{2}\left(\mathrm{~N}_{2}\right)_{2}\right]\left(\mathrm{M}=\mathrm{Mo}, 3_{\mathrm{Mo}} ; \mathrm{M}=\mathrm{W}\right.$, $3_{\mathrm{W}}$ ), with the strong LA tris(pentafluorophenyl)borane $\left(\mathrm{B}\left(\mathrm{C}_{6} \mathrm{~F}_{5}\right)_{3}, 1\right)$ in a similar fashion as reported previously with trans- $\left[\mathrm{M}(\mathrm{dppe})_{2}\left(\mathrm{~N}_{2}\right)_{2}\right]$ (2). ${ }^{12}$ Upon treatment of complexes $3_{\mathrm{Mo}}$ and $3_{\mathrm{W}}$ with $\mathbf{1}$ in toluene- $d_{8}$ at room temperature, immediate formation of a dark brown solution was observed. The major product formed in both cases $(>75 \%$ for $3_{\mathrm{Mo}}$ and $>90 \%$ for $3_{\mathrm{W}}$ according to ${ }^{31} \mathrm{P}$ NMR) is the adduct trans- $\left[\mathrm{Mo}(\text { depe })_{2}\left(\mathrm{~N}_{2}\right)\left(\mathrm{N}=\mathrm{N}-\mathrm{B}\left\{\mathrm{C}_{6} \mathrm{~F}_{5}\right\}_{3}\right)\right]\left(\mathbf{1 1}_{\mathrm{Mo}}\right)$ or trans$\left[\mathrm{W}(\text { depe })_{2}\left(\mathrm{~N}_{2}\right)\left(\mathrm{N}=\mathrm{N}-\mathrm{B}\left\{\mathrm{C}_{6} \mathrm{~F}_{5}\right\}_{3}\right)\right]\left(\mathbf{1}_{\mathrm{W}}\right)$ according to ${ }^{1} \mathrm{H}$, ${ }^{11} \mathrm{~B},{ }^{19} \mathrm{~F}$, and ${ }^{31} \mathrm{P}$ NMR spectroscopy. The two compounds show similar spectroscopic signatures with two sets of signals for the ethyl groups and ethane backbone in ${ }^{1} \mathrm{H}$ NMR. The phosphines are equivalent as evidenced by a single peak in ${ }^{31} \mathrm{P}\left\{{ }^{1} \mathrm{H}\right\} \mathrm{NMR}$ at $\delta 52.9 \mathrm{ppm}$ for $\mathbf{1 1}_{\mathrm{Mo}}$ and $\delta 34.7 \mathrm{ppm}$ for $\mathbf{1 1}_{\mathrm{W}}$ $\left(J_{\mathrm{PW}}=293 \mathrm{~Hz}\right)$, upfield-shifted compared to $\mathbf{3}_{\mathrm{Mo}}$ and $\boldsymbol{3}_{\mathrm{w}}(\delta$ 55.9 and $36.2 \mathrm{ppm}$, respectively). Diagnostic signals of borane coordination are seen in ${ }^{11} \mathrm{~B}$ and ${ }^{19} \mathrm{~F}$ NMR. Layering pentane over toluene solutions of the complexes at $-40{ }^{\circ} \mathrm{C}$ allows for their recovery as orange $\left(\mathbf{1 1}_{\mathbf{M o}}\right)$ or purple $\left(\mathbf{1 1}_{\mathrm{W}}\right)$ crystals in $53 \%$ and $62 \%$ yield, respectively. The structures of complexes $\mathbf{1} \mathbf{1}_{\mathrm{Mo}}$ and $\mathbf{1} \mathbf{1}_{\mathrm{W}}$ were confirmed by X-ray diffraction (Figure 5). The $\mathrm{M}\left(\mu-\mathrm{N}_{2}\right)\left(\mathrm{B}\left\{\mathrm{C}_{6} \mathrm{~F}_{5}\right\}_{3}\right)$ moiety features ambiguous bond orders with $\mathrm{M}-\mathrm{N}$ distances falling within simple and double bonds [1.894(4) $\AA$ for $\mathbf{1 1}_{\mathrm{Mo}}$ and 1.908(7) $\AA$ for $\mathbf{1}_{\mathrm{W}}$ vs 2.031 $\AA$ for $3_{\mathrm{Mo}}$ and $\approx 1.70-1.80 \AA$ for $\left.\mathrm{M}=\mathrm{N}\right]^{49}$ and $\mathrm{N}-\mathrm{N}$ distances for the bridging $\mathrm{N}_{2}$ ligand falling within double and triple bonds [1.174(5) $\AA$ for $\mathbf{1}_{\mathrm{Mo}_{\mathrm{Mo}}}$ and 1.180(9) $\AA$ for $\mathbf{1}_{\mathrm{W}} \mathrm{vs}$ $1.117 \AA$ for $3_{\mathrm{Mo}}$ and $1.096 \AA$ for free $\mathrm{N}_{2}$ ]. The $\mathrm{B}-\mathrm{N}$ bonds are comparable to adducts of 1 with other nitrogen bases [1.561(6) $\AA$ for $1 \mathbf{1}_{\mathrm{Mo}}$ and $1.549(11) \AA$ for $\left.\mathbf{1}_{\mathrm{W}}\right]^{50}$ The dinitrogen ligand in trans position shows longer $\mathrm{M}-\mathrm{N}$ bonds [2.128(5) $\AA$ for $1 \mathbf{1}_{\mathrm{Mo}}$ and 2.093(11) $\AA$ for $\mathbf{1 1}_{\mathrm{W}}$ ] and shorter $\mathrm{N}-\mathrm{N}$ distances $\left[1.092(7) \AA\right.$ for $\mathbf{1 1}_{\mathrm{Mo}}$ and 1.082(11) $\AA$ for $11_{\mathrm{W}}$ ] consistent with a decreased activation. The tetrahedral character of the boron atoms is $85 \%\left(\mathbf{1 1}_{\mathrm{Mo}}\right)$ and $89 \%\left(\mathbf{1 1}_{\mathrm{W}}\right) .^{51}$ FTIR-ATR spectra of the crystals feature two strong absorptions in the $2400-1600 \mathrm{~cm}^{-1}$ region, one corresponding to the stretching of the $\mathrm{N}-\mathrm{N}$ bond of the bridging $\mathrm{N}_{2}$ at 1789 $\mathrm{cm}^{-1}\left(\mathbf{1 1}_{\mathrm{Mo}}\right)$ and $1767 \mathrm{~cm}^{-1}\left(\mathbf{1 1}_{\mathrm{W}}\right.$; vs $1914 \mathrm{~cm}^{-1}$ for $3_{\mathrm{Mo}}$ and $1890 \mathrm{~cm}^{-1}$ for $\left.3_{\mathrm{W}}\right)$; the second vibration corresponds to the stretching of the $\mathrm{N}-\mathrm{N}$ bond of the monoligated $\mathrm{N}_{2}$ ligand at $2120 \mathrm{~cm}^{-1}\left(\mathbf{1 1}_{\mathrm{Mo}}\right)$ and $2076 \mathrm{~cm}^{-1}\left(\mathbf{1 1}_{\mathrm{W}}\right)$.

The retention of the second $\mathrm{N}_{2}$ ligand contrasts with the previously reported ${ }^{12}$ structures of $\left[\mathrm{Mo}(\text { dppe })_{2}(\mathrm{~N}=\mathrm{N}-\mathrm{B}\right.$ - 

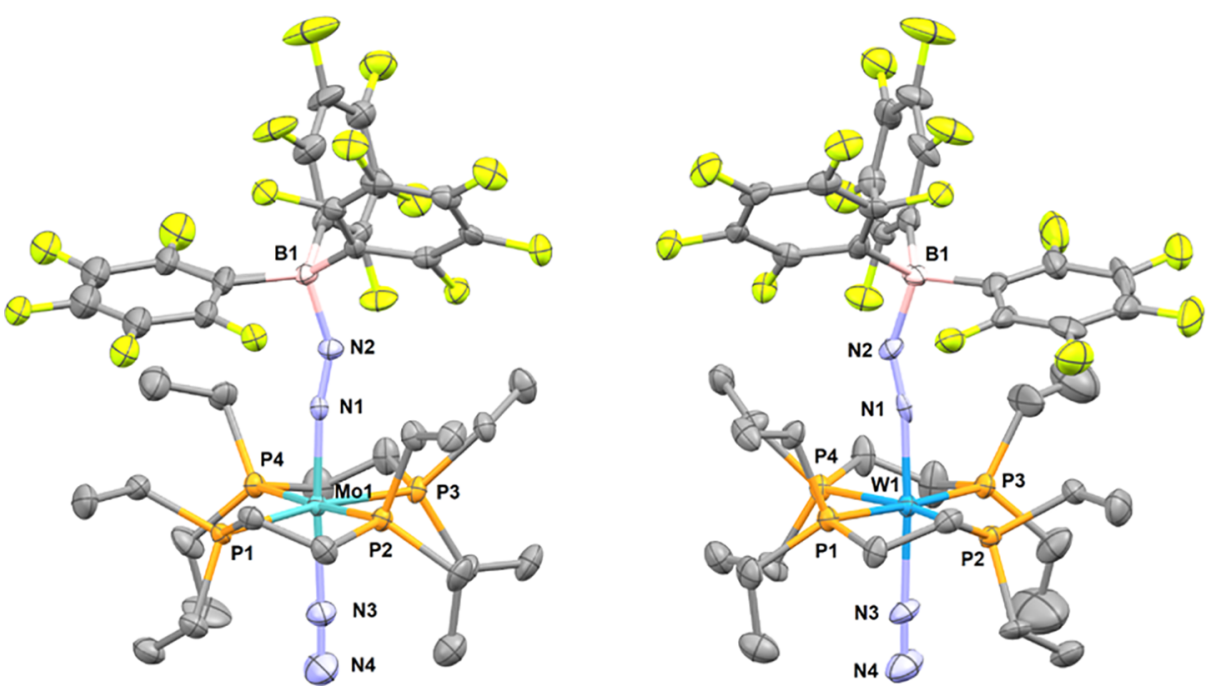

Figure 5. Molecular structure of complexes $\mathbf{1} \mathbf{1}_{\mathrm{Mo}}$ (left) and $\mathbf{1}_{\mathrm{W}}$ (right) in the solid state (ellipsoids are drawn at the $50 \%$ probability level; hydrogen atoms are omitted for clarity). Selected bond lengths $(\AA)$ and angles (deg), $1_{1}$ : Mo1-N1 1.894(4), N1-N2 1.174(5), N2-B1 1.561(6), Mo-N3 2.128(5), N3-N4 1.092(7), Mo1-N1-N2 169.9(3), N1-N2-B1 150.9(4), Mo1-N3-N4 177.9(5), N1-Mo1-N3 176.26(16), C24-B1-C36 117.8(3), C24-B1-C30 111.4(3), C36-B1-C30 104.6(4), C24-B1-N2 105.1(3), C36-B1-N2 109.8(4), C30B1-N2 107.8(4). 11 $1_{\mathrm{W}}$ W1-N1 1.908(7), N1-N2 1.180(9), N2-B1 1.549(11), W-N3 2.093(8), N3-N4 1.082 (11), W1-N1-N2 168.9(5), N1-N2-B1 148.3(7), W1-N3-N4 177.9(8), N1-W1-N3 175.7(3), C31-B1-C41 112.7(7), C31-B1-C21 104.3(6), C41-B1-C21 114.9 (7), C21-B1-N2 109.8(7), C31-B1-N2 108.1(6), C41-B1-N2 106.9 (7).

$\left.\left.\left\{\mathrm{C}_{6} \mathrm{~F}_{5}\right\}_{3}\right)\right]\left(12_{\mathrm{Mo}}\right)$ and $\left[\mathrm{W}(\mathrm{dppe})_{2}\left(\mathrm{~N}=\mathrm{N}-\mathrm{B}\left\{\mathrm{C}_{6} \mathrm{~F}_{5}\right\}_{3}\right)\right]\left(12_{\mathrm{W}}\right)$ for which the formation of the Lewis pair induced the dissociation of the second $\mathrm{N}_{2}$ ligand. This retention is likely due to the electron richness of the depe ligand compared to the dppe ligand, which increases the electronic density available at the metal center for $\pi$-backbonding. The bridging $\mathrm{N}_{2}$ ligand is slightly less elongated in complexes $\mathbf{1 1}_{\mathbf{M}}$ than in $12_{\mathrm{M}}$ as evidenced by shorter $\mathrm{N}-\mathrm{N}$ distances $(-0.02$ to -0.03 $\AA$ ). These differences correlate with the lower shift of the N$\mathrm{N}$ stretching vibrations for $\mathbf{1} \mathbf{1}_{\mathrm{M}}$ compared to $1 \mathbf{2}_{\mathrm{M}}$ (vs dinitrogen complexes $\mathbf{3}_{\mathrm{M}}$ ) observed by IR spectroscopy. Such a difference in $\mathrm{N}_{2}$ activation can be attributed to the influence of the retained $\mathrm{N}_{2}$ ligand, as d electrons involved in backbonding are delocalized over two $\mathrm{N}_{2}$ units in complexes $\mathbf{1 1}_{\mathbf{M}}$.

Adducts of 1 or $6 \mathrm{e}^{+}$with $3_{\mathrm{W}}$ show similar N-N-LA angles $\left(148.3^{\circ}\right.$ for $11_{\mathrm{W}}, 142.6^{\circ}$ for $\left.10 \mathrm{e}_{\mathrm{W}} \mathrm{BAr}{ }^{\mathrm{F}}\right)$, elongations of the $\mu$ $\mathrm{N}-\mathrm{N}$ distance $\left(1.180 \AA\right.$ for $11_{\mathrm{W}}, 1.179 \AA$ for $\left.10 \mathrm{e}_{\mathrm{W}} \mathrm{BAr} \mathrm{r}^{\mathrm{F}}\right)$, and shortening of the $\mathrm{W}-\mathrm{N}$ bond $\left(1.908 \AA\right.$ for $\mathbf{1 1}_{\mathrm{W}}, 1.896 \AA$ for $\mathbf{1 0}_{\mathrm{W}} \mathrm{BAr} \mathrm{r}^{\mathrm{F}}$ ). This closeness in $\mathrm{N}_{2}$ push-pull activation is in line with the ANs of LAs 1 and $6 a-e^{+}$, all being found between 79 and 88 . The structural similarity between $\mathbf{1 1}_{\mathrm{W}}$ and [Au$(\mathrm{NHC})]^{+}$adducts of $3_{\mathrm{W}}$ is also reflected by their similar $\mu-\mathrm{N}_{2}$ vibrational frequencies, especially when compared to $10 \mathrm{~b}_{\mathrm{W}} \mathrm{BAr}^{\mathrm{F}}$ and $10 \mathrm{e}_{\mathrm{W}} \mathrm{BAr}^{\mathrm{F}}\left(\Delta \nu_{\mathrm{NN}} \leq 5 \mathrm{~cm}^{-1}\right)$. Although 1 and cation $6 \mathrm{e}^{+}$are poorly related in terms of structure, charge, and electronegativity of their central element, their push-pull activation is comparable. Adducts $10 c_{w} B A r^{F}$ and $10 d_{w} B A r^{F}$ with the less bulky NHC substituents at gold afford greater $\mathrm{N}_{2}$ activation than in $\mathbf{1 1}_{\mathrm{W}}$. In regard to the similar properties of these $3_{\mathrm{w}}$ adducts, the predominant steric effect over the coordination of $[\mathrm{Au}(\mathrm{NHC})]^{+}$to $\mathrm{N}_{2}$ complexes is unveiled by the considerable differentiation between $12_{\mathrm{W}}$ and the related gold adducts. Indeed, $1 \mathbf{1 2}_{\mathrm{W}}$ presents a higher $\mathrm{N}_{2}$ activation $\left(\Delta \nu_{\mathrm{NN}}=-233 \mathrm{~cm}^{-1}\right.$ vs $\left.\mathbf{2}_{\mathrm{W}}\right)$ than $\mathbf{1 1}_{\mathrm{W}}$, whereas $[\mathrm{Au}(\mathrm{NHC})]^{+}$ coordination on $2_{\mathrm{W}}$ leads to weaker $\mathrm{N}_{2}$ activations than with $3_{\mathrm{W}}$ (e.g., $\Delta \nu_{\mathrm{NN}}=-95 \mathrm{~cm}^{-1}$ vs $2_{\mathrm{W}}$ for $7 \mathbf{b}_{\mathrm{W}} \mathrm{BAr}^{\mathrm{F}}$ and $-124 \mathrm{~cm}^{-1}$ vs $3_{\mathrm{W}}$ for $\mathbf{1 0 b}_{\mathrm{W}} \mathrm{BAr} \mathrm{F}^{\mathrm{F}}$ ). This difference of behaviors likely stems from the shape of the LAs as the NHCs' substituents expand toward the dppe ligands, which increases considerably the steric repulsion with the phenyl groups of the phosphine compared to the outward extending borane substituents. In addition, IR analyses of $\mathbf{2}_{\mathrm{w}}$-gold adduct solutions point to a retention of the second $\mathrm{N}_{2}$ ligand which, as mentioned above, has an influence on the activation of the bridging $\mathrm{N}_{2}$ ligand.

${ }^{15} \mathrm{~N}$-Labeling Experiments. The ${ }^{15} \mathrm{~N}$-labeled complexes ${ }^{15} \mathrm{~N}-\mathbf{1 0} \mathbf{e}_{\mathrm{W}} \mathrm{BAr}{ }^{\mathrm{F}}$ and ${ }^{15} \mathrm{~N}-\mathbf{1} \mathbf{1}_{\mathrm{W}}$ were synthesized from [W$\left({ }^{15} \mathrm{~N}_{2}\right)_{2}$ (depe $\left.)_{2}\right]\left({ }^{15} \mathrm{~N}-3_{\mathrm{W}}\right)$ following the same aforementioned procedures. FTIR-ATR analysis of the labeled complexes confirmed the identification of the $\mathrm{N}_{2}$ ligands' vibration in the ${ }^{14} \mathrm{~N}$ analogues with bathochromic shifts of $-71 \mathrm{~cm}^{-1}\left(\mathrm{~N}_{2}\right)$ and $-58 \mathrm{~cm}^{-1}\left(\mu-\mathrm{N}_{2}\right)$ for ${ }^{15} \mathrm{~N}-10 \mathrm{e}_{\mathrm{W}} \mathrm{BAr}{ }^{\mathrm{F}}$ (vs ${ }^{14} \mathrm{~N}-10 \mathrm{e}_{\mathrm{W}} \mathrm{BAr}{ }^{\mathrm{F}}$, bands at 1977 and $\left.1704 \mathrm{~cm}^{-1}\right)$ and shifts of $-69 \mathrm{~cm}^{-1}\left(\mathrm{~N}_{2}\right)$ and -58 $\mathrm{cm}^{-1}\left(\mu-\mathrm{N}_{2}\right)$ for ${ }^{15} \mathrm{~N}-11_{\mathrm{W}}$ (vs ${ }^{14} \mathrm{~N}-11_{\mathrm{W}}$, bands at 2076 and $\left.1767 \mathrm{~cm}^{-1}\right)$. The ${ }^{15} \mathrm{~N}$ NMR chemical shifts of ${ }^{15} \mathrm{~N}-10 \mathrm{e}_{\mathrm{W}} \mathrm{BAr}{ }^{\mathrm{F}}$ and ${ }^{15} \mathrm{~N}-1 \mathbf{1}_{\mathrm{W}}$ are reported in Table 2 .

Table 2. NMR Chemical Shifts of Adducts ${ }^{15} \mathrm{~N}-10 \mathrm{e}_{\mathrm{W}} \mathrm{BAr}{ }^{\mathrm{F}}$ and ${ }^{15} \mathrm{~N}-11_{\mathrm{W}}$

\begin{tabular}{|c|c|c|c|c|c|}
\hline complex & solvent & $\begin{array}{l}\delta^{15} \mathrm{~N}_{\alpha} \\
\left(\mu-\mathrm{N}_{2}\right)^{a}\end{array}$ & $\begin{array}{l}\delta^{15} \mathrm{~N}_{\beta} \\
\left(\mu-\mathrm{N}_{2}\right)^{a}\end{array}$ & $\begin{array}{l}\delta^{15} \mathrm{~N}_{\alpha} \\
\left(\mathrm{N}_{2}\right)^{\alpha}\end{array}$ & $\begin{array}{l}\delta^{15} \mathrm{~N}_{\beta} \\
\left(\mathrm{N}_{2}\right)^{a^{a}}\end{array}$ \\
\hline${ }^{15} \mathrm{~N}-\mathbf{2}_{\mathrm{W}}$ & $\mathrm{C}_{6} \mathrm{D}_{6}$ & & & -63.1 & -52.0 \\
\hline${ }^{15} \mathrm{~N}-\mathrm{e}_{\mathrm{W}} \mathrm{BAr}{ }^{\mathrm{F}}$ & $\mathrm{C}_{6} \mathrm{D}_{5} \mathrm{Cl}$ & -40.1 & -119.0 & -76.1 & -42.9 \\
\hline${ }^{15} \mathrm{~N}-\mathbf{1} \mathbf{1}_{\mathrm{W}}$ & $\mathrm{C}_{6} \mathrm{D}_{6}$ & -55.0 & -152.6 & -73.9 & -37.4 \\
\hline
\end{tabular}

Upon coordination of the Lewis acids, the terminal nitrogen $\left(\mathrm{N}_{\beta}\right)$ of the bridging $\mathrm{N}_{2}$ is significantly shielded (-67 and $-100.6 \mathrm{ppm}$ for ${ }^{15} \mathrm{~N}-\mathbf{1 0 e}_{\mathrm{W}} \mathrm{BAr}{ }^{\mathrm{F}}$ and ${ }^{15} \mathrm{~N}-11_{\mathrm{W}}$, respectively) while the tungsten bound nitrogen $\left(\mathrm{N}_{\alpha}\right)$ is slightly deshielded $\left(-23\right.$ and $-8.1 \mathrm{ppm}$ for ${ }^{15} \mathrm{~N}-10 \mathrm{e}_{\mathrm{W}} \mathrm{BAr}{ }^{\mathrm{F}}$ and ${ }^{15} \mathrm{~N}-11_{\mathrm{W}}$, respectively) compared to ${ }^{15} \mathrm{~N}-2_{\mathrm{W}}$. A similar trend was observed by Donovan-Mtunzi et al. $^{52}$ upon coordination of 

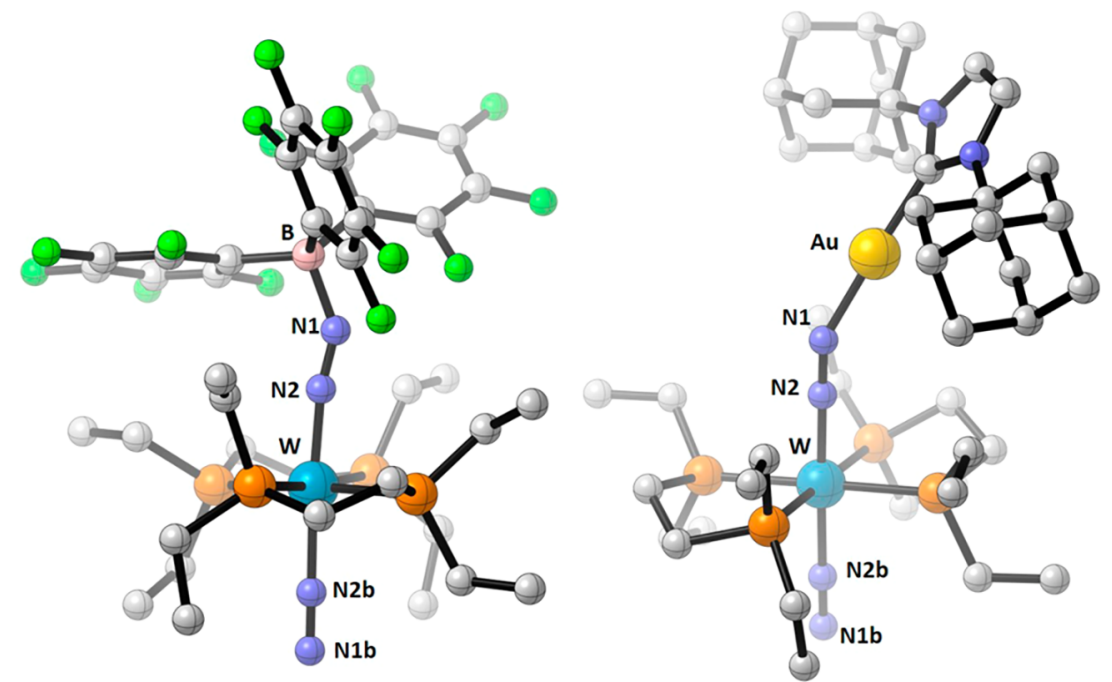

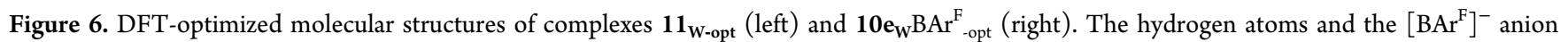
have been omitted for the sake of clarity.

Table 3. Significant Bond Distances $(\AA)$ and Angles $(\mathrm{deg})$ for $10 \mathrm{e}_{\mathrm{W}} \mathrm{BAr}{ }^{\mathrm{F}}, 10 \mathrm{e}_{\mathrm{W}} \mathrm{BAr}{ }_{\text {-opt }}^{\mathrm{F}}, 11_{\mathrm{W}}, 11_{\mathrm{W} \text {-opt }}, 3_{\mathrm{W}}$, and $3_{\mathrm{W}-\mathrm{opt}}$

\begin{tabular}{lcccccccc} 
& $\mathrm{W}-\mathrm{N} 2$ & $\mathrm{~N} 2-\mathrm{N} 1$ & $\mathrm{~N} 1-\mathrm{LA}$ & $\mathrm{W}-\mathrm{N} 2 \mathrm{~b}$ & $\mathrm{~N} 2 \mathrm{~b}-\mathrm{N} 1 \mathrm{~b}$ & $\mathrm{~W}-\mathrm{N} 2-\mathrm{N} 1$ & $\mathrm{~N} 2-\mathrm{N} 1-\mathrm{LA}$ & $\mathrm{W}-\mathrm{N} 2 \mathrm{~b}-\mathrm{N} 1 \mathrm{~b}$ \\
$\mathbf{1} \mathbf{1}_{\mathrm{W}}$ & 1.908 & 1.179 & 1.550 & 2.094 & 1.082 & 169.0 & 148.4 & 177.9 \\
$\mathbf{1 1}_{\mathrm{W} \text {-opt }}$ & 1.892 & 1.169 & 1.552 & 2.055 & 1.128 & 170.7 & 145.5 & 179.1 \\
$\mathbf{1 0}_{\mathrm{W}} \mathrm{BAr}^{\mathrm{F}}$ & 1.896 & 1.179 & 2.015 & 2.071 & 1.093 & 176.3 & 142.6 & 177.4 \\
$\mathbf{1 0}_{\mathrm{W}} \mathrm{BAr}^{\mathrm{F}}{ }_{\text {-opt }}$ & 1.905 & 1.169 & 2.002 & 2.048 & 1.129 & 178.4 & 148.8 & 177.4 \\
$3_{\mathrm{W}}$ & 2.015 & 1.123 & & 2.015 & 1.123 & 178.6 & 178.6 \\
$3_{\mathrm{W} \text {-opt }}$ & 1.999 & 1.139 & & 2.000 & 1.138 & 178.3 & & 178.3 \\
\hline
\end{tabular}

$\mathrm{AlMe}_{3}$ on various dinitrogen complexes, which contrasts with transition-metal acceptors that typically induce a deshielding of $\mathrm{N}_{\beta}$.

Computational Studies. In order to get insight into the nature of the $\mu-\mathrm{N}_{2}-\mathrm{B}\left(\mathrm{C}_{6} \mathrm{~F}_{5}\right)_{3}$ and $\mu-\mathrm{N}_{2}-[\mathrm{Au}(\mathrm{NHC})]^{+}$bonds and into the impact of the exogenous LAs on the electronic structure of the $\mathrm{M}$ (group 6) $-\mathrm{N}_{2}$ unit, we carried out a DFT computational study at the B3PW91 level of theory on the trans- $\left[\mathrm{W}(\text { depe })_{2}\left(\mathrm{~N}_{2}\right)\left(\mathrm{N}=\mathrm{N}-\mathrm{B}\left\{\mathrm{C}_{6} \mathrm{~F}_{5}\right\}_{3}\right)\right]\left(\mathbf{1}_{\mathrm{W}}\right)$ and trans$\left[\mathrm{W}(\text { depe })_{2}\left(\mathrm{~N}_{2}\right)\left(\mu-\mathrm{N}_{2}\right) \mathrm{Au}(\mathrm{IAd})\right]\left[\mathrm{BAr}^{\mathrm{F}}\right]\left(\mathbf{1 0 e}_{\mathrm{W}} \mathrm{BAr}^{\mathrm{F}}\right)$ complexes. The optimized structures of $11_{\mathrm{W}}\left(\mathbf{1 1}_{\mathrm{W} \text {-opt }}\right)$ and $10 \mathrm{e}_{\mathrm{W}} \mathrm{BAr}^{\mathrm{F}}\left(10 \mathrm{e}_{\mathrm{W}} \mathrm{BAr}^{\mathrm{F}}{ }_{\text {-opt }}\right)$ are shown in Figure 6. Their corresponding bond distances and angles are listed in Table 3 and compared with those observed experimentally for $\mathbf{1 1}_{\mathrm{W}}$ and ${ }^{10 e_{W}} \mathrm{BAr}^{\mathrm{F}}$ as well as with those of the $\left[\mathrm{W}(\text { depe })_{2}\left(\mathrm{~N}_{2}\right)_{2}\right]$ precursor $\left(3_{\mathrm{W}}\right.$ and $\left.3_{\mathrm{W} \text {-opt }}\right)$.

As shown in Table 3, the computed bond distances and angles accurately reproduce the values obtained experimentally with variations that fall within the error of the DFT method. In accordance with the experimental results, the $\mathrm{W}\left(\mu-\mathrm{N}_{2}\right)-(\mathrm{LA})$ motif presents a shortened $\mathrm{W}-\mathrm{N}$ bond (1.892 and $1.905 \AA$ for $11_{\mathrm{W}-\text { opt }}$ and $10 \mathrm{e}_{\mathrm{W}} \mathrm{BAr}^{\mathrm{F}}$-opt respectively, compared to $2.000 \AA$ for $\left.3_{\mathrm{W}-\text { opt }}\right)$ and a lengthened N1-N2 bond (1.169 $\AA$ for both $11_{\mathrm{W} \text {-opt }}$ and $10 \mathrm{e}_{\mathrm{W}} \mathrm{BAr}{ }_{\text {-opt }}$ compared to $1.139 \AA$ for $\left.3_{\mathrm{W} \text {-opt }}\right)$. The N2-N1-LA angles, in addition, measure $145.5^{\circ}$ for $11_{\mathrm{W} \text {-opt }}$ and $148.8^{\circ}$ for $10 \mathrm{e}_{\mathrm{W}} \mathrm{BAr}^{\mathrm{F}}{ }_{\text {-opt }}$, reproducing well the bent structure observed in the corresponding crystallized complexes. In order to discard the possible implication of solely steric effects in the formation of these bent structures, such as, in particular, the steric constraint between the LA ligands and the diphosphine substituents, we computed the $\mathbf{1 1}_{\mathrm{W} \text {-opt }}$ compound by replacing the pentafluorophenyl groups with trifluoromethyl ones $\left(13_{\mathrm{W}-\mathrm{opt}}\right)$ and the $10 \mathbf{e}_{\mathrm{W} \text {-opt }}{ }^{+}$complex, by replacing the adamantyl groups with methyl ones $\left(14_{\mathrm{W} \text {-opt }}{ }^{+}\right)$. As shown in Figure S94, both the new structures display acute N-N-LA angles $\left(139.0^{\circ}\right.$ for $13_{\mathrm{W}-\text { opt }}$ and $131.8^{\circ}$ for $\left.14_{\mathrm{W}-\mathrm{opt}}\right)$, pointing out that the main reason for the observed bent geometry must not be attributed to sterically induced repulsions but rather to electronic factors. The computed Wiberg bond indexes (Table S12) are in accordance with the experimental and computed geometrical parameters. While for the $\mathrm{N} 2-\mathrm{N} 1$ bond the Wiberg indexes decrease from $2.52\left(3_{\mathrm{W}-\mathrm{opt}}\right)$ to 2.10 $\left(10 \mathrm{e}_{\mathrm{W}} \mathrm{BAr}^{\mathrm{F}}{ }_{\text {-opt }}\right)$ to $2.04\left(\mathbf{1}_{\mathrm{W} \text {-opt }}\right)$, for the $\mathrm{W}-\mathrm{N} 2$ bond, on the other hand, they increase, from $0.97\left(3_{\mathrm{W}-\mathrm{opt}}\right)$ to 1.28 $\left(\mathbf{1 0 e}_{\mathrm{W}} \mathrm{BAr}^{\mathrm{F}}{ }_{\text {-opt }}\right)$ to $1.33\left(\mathbf{1}_{\mathrm{W} \text {-opt }}\right)$. This LA-induced $\mathrm{N}_{2}$ activation correlates well with the lower energies found for the computed $\mu-\mathrm{N}-\mathrm{N}$ asymmetric stretching vibrations of $11_{\text {W-opt }}$ and $10 \mathrm{e}_{\mathrm{W}} \mathrm{BAr}^{\mathrm{F}}{ }_{\text {-opt }}\left(1904\right.$ and $1880 \mathrm{~cm}^{-1}$, respectively) compared to $3_{\mathrm{W} \text {-opt }}\left(2011 \mathrm{~cm}^{-1}\right)$.

Considering a valence bond approach, the bonding situation in complexes $11_{\mathrm{W} \text {-opt }}$ and $10 \mathrm{e}_{\mathrm{W}} \mathrm{BAr}_{\text {-opt }}^{\mathrm{F}}$ falls between two extremes, that are on one side a linear $\mathrm{W}-\mathrm{N} 2-\mathrm{N} 1-\mathrm{LA}$ geometry with the $\mathrm{N} 1$ atom sp hybridized in a borata- or auryldiazenium ligand and on the other side a W-N2-N1-LA bent geometry with the $\mathrm{N} 1$ atom $\mathrm{sp}^{2}$-hybridized in a borata- or auryl diazenido ligand (Figure 7$)^{53}$

To shed light on this ambiguous situation, we computed the molecular orbitals of compounds $11_{\text {W-opt }}$ and $10 \mathbf{e}_{\mathrm{W}} \mathrm{BAr}^{\mathrm{F}}{ }_{\text {-opt }}$. For complex $\mathbf{1} \mathbf{1}_{\mathrm{W} \text {-opt, }}$ while the HOMO is essentially nonbonding at tungsten (Figure S95), the energetically close HOMO-1 and HOMO-2 orbitals show a strong backbonding donation from a filled $\mathrm{W}$ (depe $)_{2} \mathrm{~d}$ orbital to an unfilled $\mathrm{N}_{2} \pi^{*}$ orbital, displaying a significant $\mathrm{W}-\mathrm{N} \pi$-bonding 


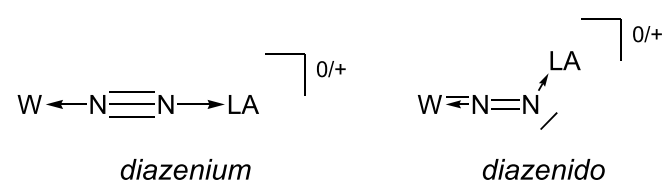

Figure 7. Lewis structures extrema for $11_{\mathrm{W}}$ and $10 \mathrm{e}_{\mathrm{W}}{ }^{+}$: diazenium vs diazenido ligand.

character, indicative of a multiple bonding between the $\mathrm{W}$ and the $\mathrm{N} 2$ atom (Figure 8).
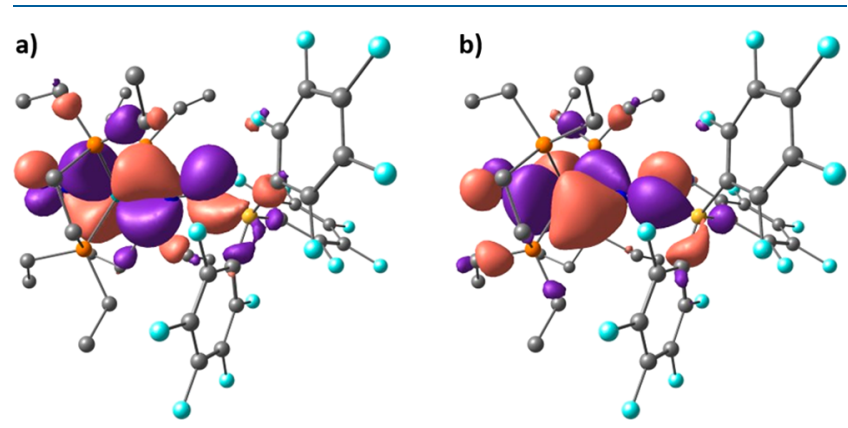

Figure 8. DFT-computed molecular orbitals of complex $\mathbf{1}_{\text {W-opt }}$ : (a) HOMO-1; (b) and HOMO-2.

While in the HOMO-1 orbital, the back-bonding donation involves the $\mathrm{W}$ (depe) $)_{2} d$ and the $\mathrm{N}_{2} \pi^{*}$ orbitals which are perpendicular to the $\mathrm{N} 2-\mathrm{N} 1-\mathrm{B}$ plane, in the HOMO-2 orbital, on the other hand, the back-bonding donation involves the $\mathrm{W}$ (depe $)_{2} \mathrm{~d}$ and $\mathrm{N}_{2} \pi^{*}$ orbitals which are coplanar to the $\mathrm{N}-\mathrm{N}-\mathrm{B}$ plane. In both the HOMO-1 and HOMO-2 molecular orbitals, interestingly, an overlap between a $\mu-\mathrm{N}_{2} \pi^{*}$ lobe and a B sp ${ }^{3}$ orbital is observed. As described by Szymczak et al., ${ }^{11 \mathrm{e}}$ this interaction is likely to lower the energy of the $\pi^{*}$ orbital in $\mathrm{N}_{2}$, leading to an augmented back-bonding donation from the $\mathrm{W}(\text { depe })_{2}$ fragment. In compound $\mathbf{1 1}_{\mathrm{W}}$, therefore, the presence of a bent rather than linear $\mathrm{N} 2-\mathrm{N} 1-\mathrm{B}$ bond angle (148.4 $4^{\circ}$ and $145.5^{\circ}$ in $11_{\mathrm{W}}$ and $\mathbf{1 1}_{\mathrm{W} \text {-opt }}$, respectively) maximizes the overlap between the $\mathrm{B} \mathrm{sp}^{3}$ orbital and a lobe of the $\mu-\mathrm{N}_{2} \pi^{*}$ orbital, the extent of the $\mathrm{N} 2-\mathrm{N} 1-\mathrm{B}$ bending being likely correlated with the steric properties of the boron substituents. Akin to $11_{\mathrm{W} \text {-opt }}$ the HOMO of $10 \mathrm{e}_{\mathrm{W}} \mathrm{BAr}^{\mathrm{F}}{ }_{\text {-opt }}$ is essentially a tungsten-localized nonbonding orbital (Figure S95), whereas the HOMO-1 and HOMO-2 show the backbonding donation from the $\mathrm{W}(\text { depe })_{2}$ to the $\mathrm{N}_{2}$ unit, with a significant $\mathrm{W}-\mathrm{N} \pi$-bonding character reflecting a multiple bonding between the $\mathrm{W}$ and the N2 centers (Figure 9). It is worth underlining here that the nonbonding nature of the HOMO d orbital in both $10 \mathbf{e}_{\mathrm{W}} \mathrm{BAr}^{\mathrm{F}}{ }_{\text {opt }}$ and $11_{\mathrm{W} \text {-opt }}$ strongly evokes the electronic structure of the $\mathrm{SiMe}_{3}{ }^{+}$adduct of the

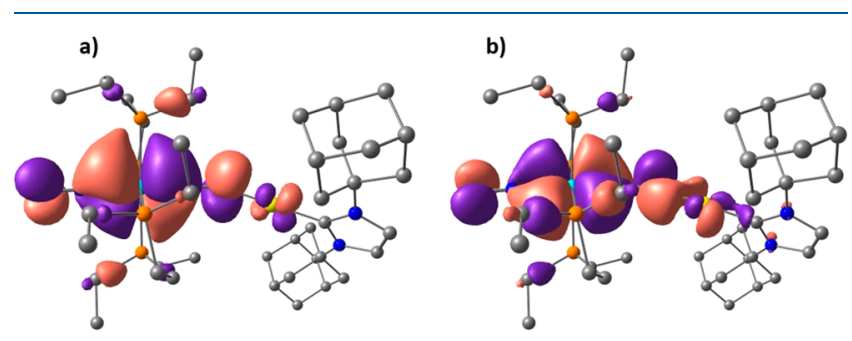

Figure 9. DFT calculated molecular orbitals of complex $10 \mathrm{e}_{\mathrm{W}} \mathrm{BAr}^{\mathrm{F}}{ }_{\text {-opt }}$ : (a) HOMO-1 and (b) HOMO-2. The $\left[\mathrm{BAr}^{\mathrm{F}}\right]^{-}$anion has been omitted for clarity. iron(0) dinitrogen complex $\left[\mathrm{Fe}\left(\mathrm{N}_{2}\right)(\text { depe })_{2}\right]$ computed by the group of Ashley. ${ }^{46}$ Like in compound $\mathbf{1 1}_{\mathrm{W} \text {-opt }}$ the HOMO-1 and HOMO-2 orbitals of complex $10 \mathbf{e}_{\mathrm{W}} \mathrm{BAr}^{\mathrm{F}}{ }_{\text {-opt }}$ (Figure 9) involve the $\mathrm{W}(\text { depe })_{2} \mathrm{~d}$ and the $\mathrm{N}_{2} \pi^{*}$ orbitals which are perpendicular and coplanar to the $\mathrm{N} 2-\mathrm{N} 1-\mathrm{Au}$ plane, respectively. In the HOMO-2 orbital, interestingly, one lobe of the $\mu-\mathrm{N}_{2} \pi^{*}$ orbital overlaps with a lobe of the $\mathrm{Au}^{+}$sd vacant orbital, partially contributing to the $\mathrm{N} 1-\mathrm{Au}^{+}$bond interaction. In contrast with compound $\mathbf{1}_{\mathbf{W - o p t}}$ in which both the HOMO-1 and HOMO-2 orbitals are bonding with respect to the $\mathrm{N} 1-\mathrm{LA}$ bond, in $\mathbf{1 0 e}_{\mathrm{W}} \mathrm{BAr}^{\mathrm{F}}$-opt this is the case for only the HOMO-2 since the HOMO-1 orbital displays an antibonding $\mathrm{N} 1-\mathrm{Au}^{+}$interaction (Figure S96). This, added to the fact that the overlap between the $\mathrm{Au}^{+}$sd orbital with the $\pi^{*}$ orbital of $\mu-\mathrm{N}_{2}$ is not optimal, may account for the experimentally observed higher lability of the $\mathrm{N}_{2}$ gold adduct compared to the $\mathrm{N}_{2}$ boron analogue.

In the HOMO-2 orbital of $10 \mathbf{e}_{\mathrm{W}} \mathrm{BAr}^{\mathrm{F}}{ }_{\text {opt }}$ in addition, the same $\mathrm{Au}^{+}$sd orbital which overlaps with the $\mathrm{N}_{2} \pi^{*}$ orbital is in turn involved in a $\pi$-backbonding donation with the $\mathrm{p}$ orbital of the carbenic carbon atom. Over recent years, the $\pi$-acceptor ability of NHCs in gold(I) complexes has received considerable attention with several experimental and theoretical studies aimed at characterizing it. ${ }^{54}$ As shown in Figure 10,

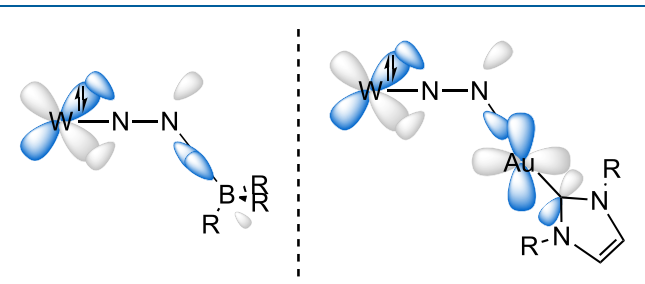

Figure 10. Simplified frontier orbital depiction accounting for the W$\mathrm{N}-\mathrm{N}-\mathrm{LA}$ bonding interaction with localized MOs.

indeed, the vacant $\mathrm{Au}^{+} \mathrm{sd}$ orbital is likely to interact at the same time with (i) the $\pi^{*}$ orbital of the bridging $\mathrm{N}_{2}$ molecule and (ii) the $p$ orbital of the carbon atom of the NHC ligand. In the HOMO-2 orbital, interestingly, the bent $\mathrm{N}-\mathrm{N}-\mathrm{Au}$ geometry $\left(142.6^{\circ}\right.$ and $148.8^{\circ}$ in $10 \mathbf{e}_{\mathrm{W}} \mathrm{BAr}^{\mathrm{F}}$ and $10 \mathbf{e}_{\mathrm{W}} \mathrm{BAr}^{\mathrm{F}}{ }_{\text {-opt }}$ respectively) allows the $\mathrm{Au}^{+}$sd orbital to improve the overlap with a lobe of the $\mu-\mathrm{N}_{2} \pi^{*}$ orbital, providing a push-pull force in the $\mathrm{N}_{2}$ activation process.

In order to get a deeper insight into the nature of this $\mu-\mathrm{N}_{2}$ $\pi^{*}-\mathrm{Au}^{+} \mathrm{sd}$ interaction, we decided to compare the molecular orbitals of $10 \mathrm{e}_{\mathrm{W}} \mathrm{BAr}^{\mathrm{F}}$ opt with those of the corresponding $\left[\mathrm{W}(\text { depe })_{2}\left(\mathrm{~N}_{2}\right)_{2}\right]\left(3_{\mathrm{W} \text {-opt }}\right)$ and $\left[\left(\mathrm{N}_{2}\right) \mathrm{Au}(\mathrm{IAd})\right]^{+}$fragments. As shown in Figure 11, the HOMO-2 orbital of $3_{\mathrm{W} \text {-opt }}$ displays a strong back-bonding donation from a filled $\mathrm{W}(\text { depe })_{2} \mathrm{~d}$ orbital to an unfilled $\mathrm{N}_{2} \pi^{*}$ orbital, like the one observed in the HOMO-2 orbital of the $\mathbf{1 0 e}_{\mathrm{W}} \mathrm{BAr}^{\mathrm{F}}{ }_{\text {opt }}$ complex. The $\left[\left(\mathrm{N}_{2}\right)\right.$ $\mathrm{Au}(\mathrm{IAd})]^{+}$fragment, on the other hand, displays a linear N$\mathrm{N}-\mathrm{Au}^{+}$geometry, which reflects the presence in its LUMO of an unfilled $\mathrm{N}_{2} \pi^{*}$ orbital. A careful analysis of this LUMO orbital shows an antibonding interaction between the unfilled $\mathrm{N}_{2} \pi^{*}$ orbital and the vacant $\mathrm{Au}^{+}$sd coplanar orbital. When the $\left[\mathrm{W}(\text { depe })_{2}\left(\mathrm{~N}_{2}\right)_{2}\right]$ and $\left[\left(\mathrm{N}_{2}\right) \mathrm{Au}(\mathrm{IAd})\right]^{+}$fragments interact, the $\mathrm{W}$ (depe $)_{2} \mathrm{~d}$ orbital may fill by back-bonding donation the $\mathrm{N}_{2}$ $\pi^{*}$ orbital of the $\left[\left(\mathrm{N}_{2}\right) \mathrm{Au}(\mathrm{IAd})\right]^{+}$cation, inducing a bend in the $\mathrm{N}-\mathrm{N}-\mathrm{Au}^{+}$angle. This $\mathrm{N}-\mathrm{N}-\mathrm{Au}^{+}$bent geometry may thus allow a partial overlap of the filled $\mathrm{N}_{2} \pi^{*}$ and the vacant $\mathrm{Au}^{+}$sd orbitals, the $\mathrm{N}_{2} \pi^{*}-\mathrm{Au}^{+}$sd interaction switching from antibonding to partially bonding. 

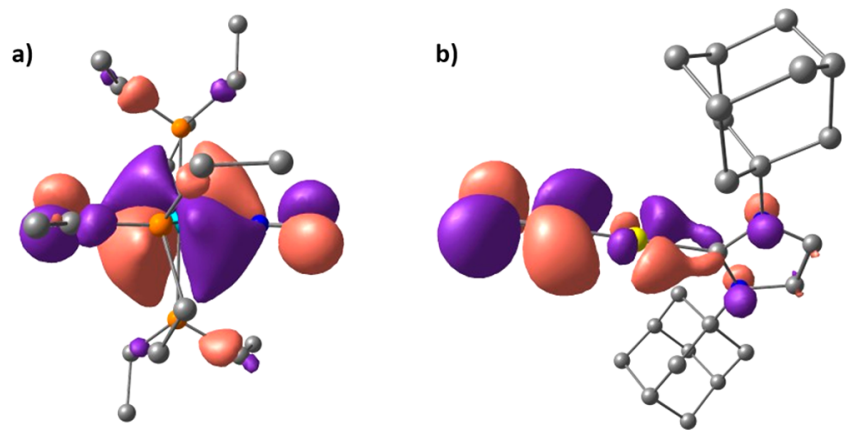

Figure 11. DFT calculated molecular orbitals of the $\left[\mathrm{W}(\text { depe })_{2}\left(\mathrm{~N}_{2}\right)_{2}\right]$ and $\left[\left(\mathrm{N}_{2}\right) \mathrm{Au}(\mathrm{IAd})\right]^{+}$fragments: (a) HOMO-2 of the [W(depe $\left.)_{2}\left(\mathrm{~N}_{2}\right)_{2}\right]$ moiety. (b) LUMO of the $\left[\left(\mathrm{N}_{2}\right) \mathrm{Au}(\mathrm{IAd})\right]^{+}$cation.

The frontier orbitals reflect therefore a partial $\mathrm{sp}^{2}$ hybridization of the $\mathrm{N} 1$ atom, underlining the predominance of the borata- or auryl diazenido form in Figure 9, due to the LAinduced push-pull effect. A careful analysis of the deeper orbitals has shown that other types of orbital overlaps also account for the N1-LA bond (Figures S97 and S98). These interactions, however, do not allow an understanding of the origin of the $\mathrm{N} 2-\mathrm{N} 1-\mathrm{LA}$ distortion, which is mainly related to the filling of the $\mu-\mathrm{N}_{2} \pi^{*}$ orbital occurring in the frontier orbitals. Another proof of the LA-induced $\mathrm{N}_{2}$ activation is given by the increase of $\mu-\mathrm{N}_{2}$ polarization as attested by the natural charges computed via an NBO analysis (Table S13). Importantly, and in line with the results of Szymczak and coworkers, ${ }^{11 \mathrm{e}}$ the negative charge of the $\mu-\mathrm{N}_{2}$ terminal nitrogen (N1) increases from -0.1 in $3_{\mathrm{W}-\mathrm{opt}}$ to -0.19 in $\mathbf{1 1}_{\mathrm{W} \text {-opt }}$ to -0.35 in $10 \mathrm{e}_{\mathrm{W}} \mathrm{BAr}^{\mathrm{F}}{ }_{\text {opt }}$ and so does the $\mathrm{N} 1-\mathrm{N} 2$ charge difference from $\Delta_{\mathrm{N} 1-\mathrm{N} 2}=0.015$ in $3_{\mathrm{W} \text {-opt }}$ to 0.31 in $\mathbf{1}_{\text {W-opt }}$ to 0.45 in $\mathbf{1 0 e}_{\mathrm{W}} \mathrm{BAr}^{\mathrm{F}}{ }_{\text {-opt }}$. In the latter compound, interestingly, the much higher negative charge on the $\mu-\mathrm{N}_{2}$ terminal nitrogen (N1) suggests that an electrostatic contribution may also account for the $\mathrm{N} 1-\mathrm{Au}^{+}$interaction. We have therefore embarked on the calculation of the natural charge of the entire $\mathrm{LA}$ acceptor fragment for complexes $\mathbf{1 1}_{\mathrm{W} \text {-opt }}$ and $\mathbf{1 0} \mathbf{e}_{\mathrm{W}} \mathrm{BAr}^{\mathrm{F}}{ }_{\text {-opt }}$ and we have estimated the force of the electrostatic interaction by comparing the charge separation between the $\mu$ - $\mathrm{N}_{2}$ terminal atom (N1) and the whole LA acceptor group. While the natural charge of the $\mathrm{B}\left(\mathrm{C}_{6} \mathrm{~F}_{5}\right)_{3}$ group in complex $\mathbf{1 1}_{\mathrm{W} \text {-opt }}$ amounts to -0.44 , that of the $\mathrm{Au}^{+}-\mathrm{NHC}$ unit in complex $\mathbf{1 0 e}_{\mathrm{W}} \mathrm{BAr}^{\mathrm{F}}$-opt measures 0.63 , providing in the latter a charge separation between the terminal $\mathrm{N} 1$ atom and the $\mathrm{Au}^{+}-\mathrm{NHC}$ moiety of $\Delta_{\mathrm{N} 1-\mathrm{LA}}=1.00$. This high level of polarization indicates that the $\mu-\mathrm{N}_{2}-\mathrm{Au}^{+}$bond has an important electrostatic component, which may in part explain the undesired redox events that have led in some instances to $\mathrm{Au}(0)$ and paramagnetic $\mathrm{W}$ species (vide supra).

Reactivity Study of $\left[\mathrm{W}\left(\mathrm{N}_{2}\right)(\text { depe })_{2}\left(\mu-\mathrm{N}_{2}\right) \mathrm{Au}(\mathrm{NHC})\right]^{+}$ Adducts in Solution and Isolation of a Tungsten Decomposition Product. To assess whether the rapid decomposition of complexes $\mathbf{1 0 b}-\mathbf{e}_{\mathrm{W}} \mathrm{BAr} \mathrm{r}^{\mathrm{F}}$ precluded their use in dinitrogen transformation reactions, we formed the adducts in situ in chlorobenzene- $d_{5}$ and added immediately 1 equiv of unsaturated organic substrates of various natures at RT, having in mind to exploit the carbophilic properties of gold to promote $\mathrm{N}_{2}$ functionalization via $\mathrm{N}-\mathrm{C}$ bond formation. According to NMR and GC-MS analysis of the solution, 2-butyne, 3-methyl-1,2-butadiene, or diisopropylcarbodiimide did not react while the adducts decomposed to mixtures of paramagnetic materials. Surprisingly, under the same conditions, we observed a deuteration of the olefinic protons of 1-octene with full deuteration of the hydrogen atom in the 2-position and partial deuteration at the 1-position after $18 \mathrm{~h}$ at RT with $\mathbf{1 0 d}_{\mathrm{W}} \mathrm{BAr}{ }^{\mathrm{F}}$, as evidenced by ${ }^{1} \mathrm{H}$ NMR spectroscopy and GC-MS analysis (most abundant ion: 113.13 $m / z=1$-octene +1$)$. Up to 20 equiv of 1 -octene can be deuterated in the presence of ${ }^{10 d_{W}} \mathrm{BAr}^{\mathrm{F}}$ at $\mathrm{RT}$ in cholorobenzene- $d_{5}$, with $90 \%$ and $35 \%$ conversion of the 2 and 1-positions, respectively, after 5 days. While neither $3_{\mathrm{W}}$ nor gold cations alone react with 1 -octene, the $\mathrm{H} / \mathrm{D}$ exchange is unlikely to be catalyzed by the adducts considering that the activity of the reaction is unrelated to the evolution of the adducts' concentration as they decompose.

Attempts to isolate or characterize the species formed from the decomposition of the gold adducts in the presence of the organic substrate have been mostly unsuccessful at the exception of the dinuclear salt $\left[\left\{\mathrm{W}(\mathrm{Cl})(\text { depe })_{2}\right\}_{2}\left(\mu-\mathrm{N}_{2}\right)\right]$ $\left[\mathrm{BAr}{ }^{\mathrm{F}}\right]_{2}$ formed in $\mathrm{ca} .40 \%$ yield (relative to $\mathrm{W}$ content) as deep green crystals precipitating out of the reaction solutions over a period of days in the presence of 3-methyl-1,2-butadiene or diisopropylcarbodiimide. While sufficient to identify this species with good confidence, the low quality of these crystals did not allow for a full structural resolution by X-ray diffraction analysis and their very poor solubility in usual solvent hindered recrystallization attempts. In the presence of organic substrates, isolated adduct ${ }^{10 d_{W}} \mathrm{BAr}^{\mathrm{F}}$ solubilized in chlorobenzene at RT afforded the W(II) complex in similar yield to that for adducts formed in situ from the reaction of $3_{\mathrm{W}}$ with $\mathrm{Na}\left[\mathrm{BAr}{ }^{\mathrm{F}}\right]$ and $[\mathrm{Au}(\mathrm{Cl})(\mathrm{NHC})]$; such a result would suggest that the chloride atoms originate from chlorobenzene. To strictly rule out the sourcing of the chloride ligand from a trace amount of $\mathrm{NaCl}$, we synthesized $\left.\left[\mathrm{Au}\left(\mathrm{NTf}_{2}\right)\left(\mathrm{Me}_{2} \mathrm{Idipp}\right)\right](\mathbf{6} \mathbf{b N T f})_{2}\right)$, following a literature procedure. ${ }^{30}$ This complex reacts immediately with 1 equiv of $3_{\mathrm{W}}$ at RT in chlorobenzene- $d_{5}$ to afford [W( $\left.\mathrm{N}_{2}\right)$ (depe) $\left.{ }_{2}\left(\mu-\mathrm{N}_{2}\right) \mathrm{Au}\left(\mathrm{Me}_{2} \mathrm{Idipp}\right)\right]\left[\mathrm{NTf}_{2}\right] \quad \mathbf{1 0 b}_{\mathrm{W}} \mathrm{NTf}_{2}$, characterized in solution by almost identical ${ }^{1} \mathrm{H}$ and ${ }^{31} \mathrm{P}$ NMR and IR $\left(\nu_{\mathrm{NN}}=1796 \mathrm{~cm}^{-1}\right.$ in $\left.\mathrm{PhCl}\right)$ spectroscopic signatures to those of $10 b_{W} B A r^{F}$. By contrast, reaction of $6 \mathbf{b N T f} f_{2}$ with $2_{W}$ affords only a minor quantity of the putative adduct $\left[\mathrm{W}\left(\mathrm{N}_{2}\right)\right.$ (dppe) ${ }_{2}\left(\mu-\mathrm{N}_{2}\right) \mathrm{Au}\left(\mathrm{Me}_{2}\right.$ Idipp $\left.)\right]\left[\mathrm{NTf}_{2}\right]$, as the displacement of the more coordinating $\mathrm{NTf}_{2}$ anion by $2_{\mathrm{W}}$ is very slow $(<20 \%$ after $24 \mathrm{~h}$ ) and evolves to a mixture of paramagnetic materials upon longer reaction times or a temperature increase to $45^{\circ} \mathrm{C}$.

In chlorobenzene, $\mathbf{1 0 b}_{\mathrm{W}} \mathrm{NTf}_{2}$ decomposes to an intractable mixture from which deep green crystals had formed after 2 days at RT. Structural determination by X-ray diffraction allowed the identification of these green crystals as the complex $\left[\left\{\mathrm{W}(\mathrm{Cl})(\text { depe })_{2}\right\}_{2}\left(\mu-\mathrm{N}_{2}\right)\right]\left[\mathrm{NTf}_{2}\right]_{2}\left(\mathbf{1 5}_{\mathrm{W}}\left[\mathrm{NTf}_{2}\right]_{2}\right)$. In contrast with its $\left[\mathrm{BAr}^{\mathrm{F}}\right]^{-}$counterpart, decomposition of $10 \mathrm{~b}_{\mathrm{W}} \mathrm{NTf}_{2}$ led to the formation of these characteristic green crystals even in absence of organic substrates; the weakly coordinating $\mathrm{NTf}_{2}$ anion is therefore assumed to play a similar role to the weakly coordinating organic substrates in the decomposition process. The homobimetallic dication $\left[\left\{\mathrm{W}(\mathrm{Cl})(\text { depe })_{2}\right\}_{2}\left(\mu-\mathrm{N}_{2}\right)\right]^{2+}$ depicted in Figure 12 features a linear $(\mathrm{Cl}-\mathrm{W})_{2}\left(\mu-\mathrm{N}_{2}\right)$ motif with short $\mathrm{W}-\mathrm{N}$ distances $(1.815(5), 1.804(5) \AA)$ and a long $\mathrm{N}-\mathrm{N}$ bond length $(1.273(7) \AA)$ that are almost identical to the dimension of the previously reported $\left\{\mathrm{Cp} * \mathrm{~W}\left[\mathrm{~N}\left({ }^{i} \mathrm{Pr}\right) \mathrm{C}\right.\right.$ $\left.\left.(\mathrm{Me}) \mathrm{N}\left({ }^{i} \mathrm{Pr}\right)\right]\right\}_{2}\left(\mu-\mathrm{N}_{2}\right)^{55}$ and consistent with an electronic configuration lying somewhere between a pair of W(II) centers bridged by an activated $\left(\mathrm{N}_{2}\right)^{0}$ ligand and a pair of $\mathrm{W}(\mathrm{IV})$ centers bridged by a $\left(\mathrm{N}_{2}\right)^{4-}$ group. 


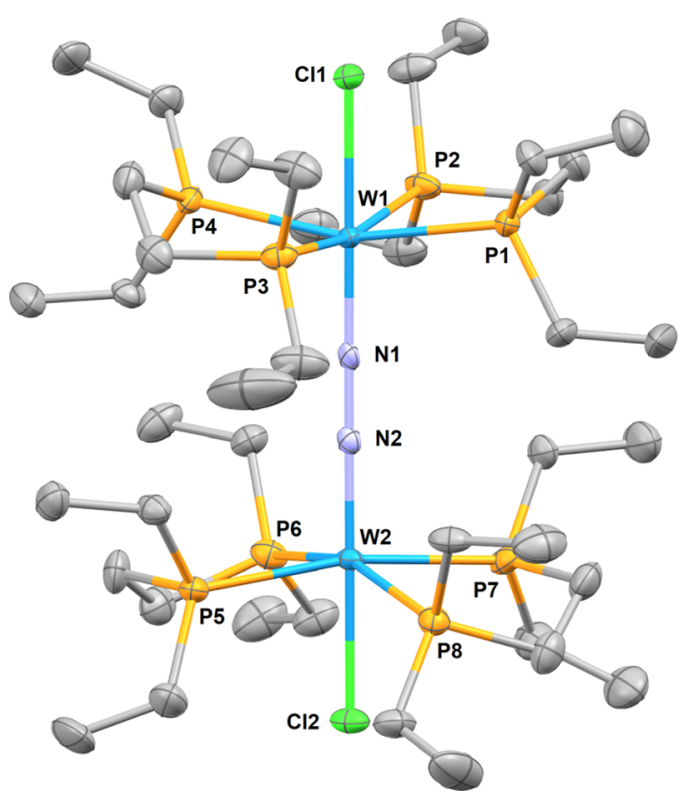

Figure 12. Molecular structure of $\left[\left\{\mathrm{W}(\mathrm{Cl})(\text { depe })_{2}\right\}_{2}\left(\mu-\mathrm{N}_{2}\right)\right]^{2+}$ $\left(15_{\mathrm{W}}{ }^{2+}\right)$ in the solid state (ellipsoids are drawn at the $50 \%$ probability level, hydrogen atoms, and $\mathrm{NTf}_{2}$ anions are omitted for clarity). Selected bond lengths $(\AA)$ and angles (deg): W1-Cl1 2.4550(16), $\mathrm{W} 1-\mathrm{N} 1$ 1.816(5), N1-N2 1.272(7), W2-N2 1.805(5), W2-Cl2 2.4663(16), Cl1-W1-N1 179.34(18), N2-W2-Cl2 178.93(18), W1-N1-N2 179.0(5), W2-N2-N1 179.3(5).

Evidently, the formation of $15_{\mathrm{W}}\left[\mathrm{NTf}_{2}\right]_{2}$ from $10 \mathbf{b}_{\mathrm{W}} \mathrm{NTf}_{2}$ results from the activation of chlorobenzene; this assumption can be confirmed by GC-MS analysis of the mixture after the formation of $15_{\mathrm{W}}\left[\mathrm{NTf}_{2}\right]_{2}$ allowing the identification of the major organic residue present in solution as isomers of chlorobenzene coupling compounds $\mathrm{Ph}-\mathrm{Ph}, \mathrm{Ph}-\mathrm{C}_{6} \mathrm{H}_{4} \mathrm{Cl}$, and $\mathrm{C}_{6} \mathrm{H}_{4} \mathrm{Cl}-\mathrm{C}_{6} \mathrm{H}_{4} \mathrm{Cl}$ (see the Supporting Information, pp 8-9). A plausible explanation for such observation could be the initial oxidation of the $\mathrm{W}$ center by the gold cation followed by the generation of aryl radicals. However, the formation of multiple paramagnetic materials resisting the characterization attempts and $\mathrm{Au}(0)$ propensity to form nanoparticles did not allow us to make any meaningful proposition regarding the mechanism responsible for the formation of biaryls and $15_{\mathrm{W}}\left[\mathrm{NTf}_{2}\right]_{2}$.

Summary and Conclusions. To assess whether gold's well-known carbophilicity could be exploited to promote new transformation of $\mathrm{N}_{2}$, the coordination properties and electronic compatibility of $\left[\mathrm{Au}^{\mathrm{I}}(\mathrm{NHC})\right]$ cations with zerovalent group 6 dinitrogen complexes trans- $\left[\mathrm{M}(\mathrm{dppe})_{2}\left(\mathrm{~N}_{2}\right)_{2}\right]$ $\left(2_{\mathrm{M}}\right)$, trans- $\left[\mathrm{M}(\text { depe })_{2}\left(\mathrm{~N}_{2}\right)_{2}\right]\left(\mathbf{3}_{\mathrm{M}}\right)$, and $\left[\mathrm{M}\left(\mathrm{PMe} \mathrm{Ph}_{2}\right)_{4}\left(\mathrm{~N}_{2}\right)_{2}\right]$ $\left(4_{M}\right)$ were explored $(\mathrm{M}=\mathrm{Mo}$ or $\mathrm{W})$. Unprecedented $\mathrm{M}(\mu$ $\left.\mathrm{N}_{2}\right)-\mathrm{Au}^{+}$Lewis pairs have been observed by spectroscopic methods. Heterobimetallic complexes $\left[\mathrm{W}\left(\mathrm{N}_{2}\right)(\mathrm{dppe})_{2}\left(\mu-\mathrm{N}_{2}\right)\right.$ $\mathrm{Au}(\mathrm{NHC})]\left[\mathrm{BAr}^{\mathrm{F}}\right] \quad\left[\mathrm{NHC}=\operatorname{Idipp}\left(7 \mathrm{a}_{\mathrm{W}} \mathrm{BAr}^{\mathrm{F}}\right) ; \mathrm{Me}_{2} \mathrm{Idipp}\right.$ $\left.\left(7 \mathbf{b}_{\mathrm{W}} \mathrm{BAr}{ }^{\mathrm{F}}\right)\right]$ and $\left[\mathrm{W}\left(\mathrm{N}_{2}\right)(\text { depe })_{2}\left(\mu-\mathrm{N}_{2}\right) \mathrm{Au}(\mathrm{NHC})\right]\left[\mathrm{BAr}^{\mathrm{F}}\right]$ $\left[\mathrm{NHC}=\mathrm{Me}_{2} \operatorname{Idipp}\left(\mathbf{1 0 b}_{\mathrm{W}} \mathrm{BAr}^{\mathrm{F}}\right) ; \operatorname{IMes}\left(\mathbf{1 0 c}_{\mathrm{W}} \mathrm{BAr}^{\mathrm{F}}\right) ; \mathrm{I}^{t} \mathrm{Bu}\right.$ $\left(\operatorname{10d}_{\mathrm{W}} \mathrm{BAr}{ }^{\mathrm{F}}\right)$; IAd $\left.\left(10 \mathrm{e}_{\mathrm{W}} \mathrm{BAr} \mathrm{r}^{\mathrm{F}}\right)\right]$ have been obtained from the reaction of the $\mathrm{N}_{2}$ complex with the appropriate $[\mathrm{Au}(\mathrm{NHC})]$ cation generated in situ from $[\mathrm{Au}(\mathrm{Cl})(\mathrm{NHC})]$ and $\mathrm{Na}\left[\mathrm{BAr}{ }^{\mathrm{F}}\right]$ and could be isolated in satisfying yields and purity, while the adducts formed with the Mo complexes have shown poor solution stability, precluding isolation. Indeed, the formation of the targeted gold adducts have been shown to be in competition with multiple side reactions, resulting in short- lived adducts in most conditions and an extreme sensitivity of the few characterizable heterobimetallic complexes discussed in this study. Gold coordination to $\mathrm{N}_{2}$ is weaker than that to phosphines, which results readily in phosphine abstraction to form heteroleptic gold complexes driven by either the relief of steric crowding or weak coordination to the group 6 metal and favored when the gold center bears low steric bulk. These reactions can be mitigated by the use of chelating phosphines and/or bulky NHCs but are responsible nevertheless for the lack of long-lived characterizable molybdenum complexes, whose coordination by phosphines is weaker than tungsten. The use of a bulky substituent at gold's NHC ligand can lead to weak $\mathrm{N}_{2}$ coordination as seen with $7 \mathrm{a}_{\mathrm{W}} \mathrm{BAr}{ }^{\mathrm{F}}$ and $7 \mathbf{b}_{\mathrm{w}} \mathrm{BAr}{ }^{\mathrm{F}}$ that readily decompose to trans- $\left[\mathrm{W}(\mathrm{dppe})_{2}\left(\mathrm{~N}_{2}\right)_{2}\right]$ as a result of gold dissociation and subsequent decomposition. Likewise, the use of the more electron donating depe ligands for the dinitrogen complex prevents gold dissociation as a result of a more electron-rich $\mathrm{N}_{2}$ ligand. However, this also favored electron transfers from the group 6 metal to the gold cations to lead gradually to mixtures of paramagnetic materials. In the sufficiently long-lived adducts $7 \mathbf{a}-\mathbf{b}_{\mathrm{W}} \mathrm{BAr} \mathrm{r}^{\mathrm{F}}$ and $\mathbf{1 0 a}-\mathbf{e}_{\mathrm{W}} \mathrm{BAr} \mathrm{r}^{\mathrm{F}}$, the push-pull activation of the bridging $\mathrm{N}_{2}$ ligand is weak to moderate as characterized by the $\Delta \nu_{\mathrm{NN}}$ ranging from -95 $\mathrm{cm}^{-1}$ to $-160 \mathrm{~cm}^{-1}$, with higher degrees of $\mathrm{N}-\mathrm{N}$ bond weakening found when the least hindered gold cation was employed.

For comparative purposes, adducts $\mathbf{1 1}_{\mathrm{M}}$ of the depesupported $3_{M}$ complexes with the strong, archetypical boron Lewis acid $\mathrm{B}\left(\mathrm{C}_{6} \mathrm{~F}_{5}\right)_{3}$ (1) have been prepared and fully characterized. Especially relevant is the comparison of the structurally characterized heterobimetallic complex $\left[\mathrm{W}\left(\mathrm{N}_{2}\right)\right.$ (depe) $\left.{ }_{2}\left(\mu-\mathrm{N}_{2}\right) \mathrm{Au}(\mathrm{IAd})\right]\left[\mathrm{BAr}^{\mathrm{F}}\right]\left(\mathbf{1 0} \mathbf{e}_{\mathrm{W}} \mathrm{BAr}^{\mathrm{F}}\right)$ with $\mathbf{1}_{\mathrm{w}}$. As judged by $\Delta \nu_{\mathrm{NN}}$ gained from IR spectroscopy, the level of push-pull activation of the bridging $\mathrm{N}_{2}$ ligand is comparable and moderate $\left(10 \mathrm{e}_{\mathrm{W}} \mathrm{BAr}^{\mathrm{F}},-126 \mathrm{~cm}^{-1} ; 11_{\mathrm{W}},-123 \mathrm{~cm}^{-1}\right.$ vs $\left.3_{\mathrm{W}}\right)$. Solid-state molecular structures of $10 \mathrm{e}_{\mathrm{W}} \mathrm{BAr}^{\mathrm{F}}$ and $1 \mathbf{1}_{\mathrm{W}}$ both show a bent $\mathrm{N}-\mathrm{N}-\mathrm{LA}$ motif, with similar angles of $143^{\circ}$ and $148^{\circ}$, respectively, and identical $\mathrm{N}-\mathrm{N}$ bond elongations (ca. $+0.05 \AA$ ). This similarity of gold with a main group Lewis acid $^{14,56}$ must be qualified in light of the DFT calculations. They have shown that, while in the presence of the boron LA, the $\mu-\mathrm{N}_{2}-\mathrm{LA}$ bond formation involves the mixing of $\mu-\mathrm{N}_{2} \pi^{*}$ orbitals with $\mathrm{sp}^{3}$ hybrid orbitals at boron, in the gold case, a $\mu$ $\mathrm{N}_{2} \pi^{*}$ orbital mixes with an sd hybrid orbital located at the gold center. In the $\mathrm{Au}^{+}$adduct, interestingly, the vacant $\mathrm{p}$ orbital of the ancillary NHC ligand also participates in this $\mu$ $\mathrm{N}_{2} \pi^{*}-\mathrm{Au}^{+}$sd bonding interaction. The natural charges computed via an $\mathrm{NBO}$ analysis indicate that the charge separation between the terminal $\mathrm{N} 1$ atom and the $\mathrm{Au}^{+}-\mathrm{NHC}$ moiety is larger than the one between the former and the $\mathrm{B}\left(\mathrm{C}_{6} \mathrm{~F}_{5}\right)_{3}$ group, suggesting an important electrostatic component in the $\mu-\mathrm{N}_{2}-[\mathrm{Au}(\mathrm{NHC})]^{+}$bond. For both compounds, finally, the presence of a bent rather than linear $\mathrm{N}-\mathrm{N}-\mathrm{LA}$ bond angle $\left(148.4^{\circ}\right.$ and $142.6^{\circ}$ in $11_{\mathrm{W}}$ and $\mathbf{1 0 e}_{\mathrm{W}} \mathrm{BAr}{ }^{\mathrm{F}}$, respectively), maximizes the overlap between a lobe of the $\mu-\mathrm{N}_{2} \pi^{*}$ orbital and either a B sp ${ }^{3}$ orbital $\left(\mathbf{1 1}_{\mathrm{W}}\right)$ or the $\mathrm{Au}^{+}$sd orbital, the extent of the N-N-LA bending being likely correlated with the steric properties of the LA substituents. The lower $\mu-\mathrm{N}_{2} \pi^{*}-\mathrm{Au}^{+}$sd bonding overlap, compared to the $\mu-\mathrm{N}_{2} \pi^{*}-\mathrm{B} \mathrm{sp}^{3}$ interaction, is compensated by a more important electrostatic character for the $\mu-\mathrm{N}_{2}-\mathrm{Au}^{+}$ bonding than for the $\mu-\mathrm{N}_{2}-\mathrm{B}$ one. This may therefore explain 
why gold coordination results ultimately in similar effects to those of $\mathrm{B}\left(\mathrm{C}_{6} \mathrm{~F}_{5}\right)_{3}$ complexation.

Preliminary reactivity experiments on the few stable gold adducts with unsaturated organic substrates lead in most conditions to the recovery of the latter and the formation of a mixture of paramagnetic materials among which $[\{\mathrm{W}(\mathrm{Cl})$ $\left.\left.(\text { depe })_{2}\right\}_{2}\left(\mu-\mathrm{N}_{2}\right)\right]\left[\mathrm{BAr}^{\mathrm{F}}\right]_{2}\left(\mathbf{1 5}_{\mathrm{W}}\left[\mathrm{BAr}^{\mathrm{F}}\right]_{2}\right)$ could be identified. This bridged tungsten dication can be isolated under the same conditions from $\left[\mathrm{W}\left(\mathrm{N}_{2}\right)(\text { depe })_{2}\left(\mu-\mathrm{N}_{2}\right) \mathrm{Au}(\mathrm{NHC})\right]\left[\mathrm{NTf}_{2}\right]$ $\left(15_{\mathrm{W}}\left[\mathrm{NTf}_{2}\right]_{2}\right)$ solutions, the chloride ligand being sourced under an unknown mechanism from chlorobenzene, of which coupling products have been identified by GC-MS analysis. These reactions were accompanied by $\mathrm{H} / \mathrm{D}$ exchange reactions of 1-octene olefinic protons. Although the mechanisms and active species of these transformations are unknown, the heterobimetallic adducts are unlikely to be involved. The sum of these observations is indicative of a redox incompatibility between gold(I) complexes and group 6 metals, which preclude their combined use in the envisioned gold promoted $\mathrm{N}_{2}$ reactivity with unsaturated $\mathrm{C}-\mathrm{C}$ bonds. Exploration of less reductive $\mathrm{Re}^{\mathrm{I}}-\mathrm{N}_{2}$ complexes is a possible development to mitigate electronic transfers.

\section{ASSOCIATED CONTENT}

\section{SI Supporting Information}

The Supporting Information is available free of charge at https://pubs.acs.org/doi/10.1021/acs.inorgchem.0c03271.

Spectroscopic characterization and additional experimental protocols, figures, and tables; Cartesian coordinates from crystallography data; and Cartesian coordinates of all optimized stationary points (PDF)

\section{Accession Codes}

CCDC 2009824-2009828, 2036361 and 2054787 contain the supplementary crystallographic data for this paper. These data can be obtained free of charge via www.ccdc.cam.ac.uk/data request/cif, or by emailing data_request@ccdc.cam.ac.uk, or by contacting The Cambridge Crystallographic Data Centre, 12 Union Road, Cambridge CB2 1EZ, UK; fax: + 441223 336033.

\section{AUTHOR INFORMATION}

\section{Corresponding Authors}

Chiara Dinoi - LPCNO, CNRS, and INSA, Université Paul Sabatier, 31077 Toulouse, France; 이이.org/0000-00022097-9696; Email: cdinoi@insa-toulouse.fr

Antoine Simonneau - LCC-CNRS, Université de Toulouse, CNRS, UPS, F-31077 Toulouse cedex 4, France;

(1) orcid.org/0000-0003-4612-284X;

Email: antoine.simonneau@lcc-toulouse.fr

\section{Authors}

David Specklin - LCC-CNRS, Université de Toulouse, CNRS, UPS, F-31077 Toulouse cedex 4, France

Anaïs Coffinet - LCC-CNRS, Université de Toulouse, CNRS, UPS, F-31077 Toulouse cedex 4, France

Laure Vendier - LCC-CNRS, Université de Toulouse, CNRS, UPS, F-31077 Toulouse cedex 4, France

Iker del Rosal - LPCNO, CNRS, and INSA, Université Paul Sabatier, 31077 Toulouse, France

Complete contact information is available at: https://pubs.acs.org/10.1021/acs.inorgchem.0c03271
Funding

ERC Starting Grant (agreement 757501).

Notes

The authors declare no competing financial interest.

\section{ACKNOWLEDGMENTS}

D.S. and A.S. acknowledge the European Research Council (ERC) for funding (Grant Agreement 757501). A.C. is grateful to the French Ministry of National and Superior Education and Research (MENESR) for a Ph.D. fellowship. This work was performed using HPC resources from CALMIP (Grant 2017[p17010]).

\section{REFERENCES}

(1) (a) Transition Metal-Dinitrogen Complexes: Preparation and Reactivity; Nishibayashi, Y., Ed.; Wiley-VCH Verlag GmbH \& Co. KGaA: Weinheim, Germany, 2019. (b) Nitrogen Fixation; Nishibayashi, Y., Ed.; Springer International Publishing AG: Cham, Switzerland, 2017. (c) Walter, M. D. Recent Advances in Transition Metal-Catalyzed Dinitrogen Activation. In Adv. Organomet. Chem.; Pérez, P. J., Ed.; Academic Press, 2016; Vol. 65, pp 261-377. (d) Khoenkhoen, N.; de Bruin, B.; Reek, J. N. H.; Dzik, W. I. Reactivity of Dinitrogen Bound to Mid- and Late-Transition-Metal Centers. Eur. J. Inorg. Chem. 2015, 2015, 567-598. (e) MacKay, B. A.; Fryzuk, M. D. Dinitrogen Coordination Chemistry: On the Biomimetic Borderlands. Chem. Rev. 2004, 104, 385-402. (f) Gambarotta, S.; Scott, J. Multimetallic Cooperative Activation of $\mathrm{N}_{2}$. Angew. Chem., Int. Ed. 2004, 43, 5298-5308. (g) Singh, D.; Buratto, W. R.; Torres, J. F.; Murray, L. J. Activation of Dinitrogen by Polynuclear Metal Complexes. Chem. Rev. 2020, 120, 5517-5581.

(2) (a) Ertl, G. Reactions at Surfaces: From Atoms to Complexity (Nobel Lecture). Angew. Chem., Int. Ed. 2008, 47, 3524-3535. (b) Schlögl, R. Catalytic Synthesis of Ammonia-A "Never-Ending Story"? Angew. Chem., Int. Ed. 2003, 42, 2004-2008. (c) Smil, V. Enriching the Earth: Fritz Haber, Carl Bosch, and the Transformation of World Food Production; MIT Press, 2001. (d) Jennings, J. R. Catalytic Ammonia Synthesis: Fundamentals and Practice; Fundamental and Applied Catalysis; Springer, 1991.

(3) Hoffman, B. M.; Lukoyanov, D.; Yang, Z.-Y.; Dean, D. R.; Seefeldt, L. C. Mechanism of Nitrogen Fixation by Nitrogenase: The Next Stage. Chem. Rev. 2014, 114, 4041-4062.

(4) (a) Foster, S. L.; Bakovic, S. I. P.; Duda, R. D.; Maheshwari, S.; Milton, R. D.; Minteer, S. D.; Janik, M. J.; Renner, J. N.; Greenlee, L. F. Catalysts for Nitrogen Reduction to Ammonia. Nat. Catal. 2018, 1 , 490-500. (b) Stucke, N.; Flöser, B. M.; Weyrich, T.; Tuczek, F. Nitrogen Fixation Catalyzed by Transition Metal Complexes: Recent Developments. Eur. J. Inorg. Chem. 2018, 2018, 1337-1355. (c) Djurdjevic, I.; Einsle, O.; Decamps, L. Nitrogenase Cofactor: Inspiration for Model Chemistry. Chem. - Asian J. 2017, 12, 14471455. (d) Roux, Y.; Duboc, C.; Gennari, M. Molecular Catalysts for $\mathrm{N}_{2}$ Reduction: State of the Art, Mechanism, and Challenges. ChemPhysChem 2017, 18, 2606-2617. (e) Nishibayashi, Y. Recent Progress in Transition-Metal-Catalyzed Reduction of Molecular Dinitrogen under Ambient Reaction Conditions. Inorg. Chem. 2015, 54, 9234-9247. (f) Jia, H.-P.; Quadrelli, E. A. Mechanistic Aspects of Dinitrogen Cleavage and Hydrogenation to Produce Ammonia in Catalysis and Organometallic Chemistry: Relevance of Metal Hydride Bonds and Dihydrogen. Chem. Soc. Rev. 2014, 43, 547-564.

(5) Ashida, Y.; Arashiba, K.; Nakajima, K.; Nishibayashi, Y. Molybdenum-Catalysed Ammonia Production with Samarium Diiodide and Alcohols or Water. Nature 2019, 568, 536-540.

(6) Coffinet, A.; Simonneau, A.; Specklin, D. Push-Pull Activation of $\mathrm{N}_{2}$ : Coordination of Lewis Acids to Dinitrogen Complexes. In Encyclopedia of Inorganic and Bioinorganic Chemistry, Scott, R.A., Ed.; John Wiley and Sons, Inc., 2020. DOI: 10.1002/ 9781119951438.eibc2755. 
(7) (a) Chatt, J.; Dilworth, J. R.; Gunz, H. P.; Leigh, G. J.; Sanders, J. $\mathrm{R}$. The Interaction of Dinitrogen Complexes of Rhenium and Osmium with Metal Salts. J. Chem. Soc. D 1970, 2, 90-91. (b) Chatt, J.; Dilworth, J. R.; Leigh, G. J.; Richards, R. L. Polynuclear Dinitrogen Complexes. J. Chem. Soc. D 1970, 15, 955-956. (c) Chatt, J.; Crabtree, R. H.; Richards, R. L. Dinitrogen- and Carbonyl-Complexes as Bases towards Trimethylaluminium. J. Chem. Soc., Chem. Commun. 1972, 9, 534. (d) Chatt, J.; Crabtree, R. H.; Jeffery, E. A.; Richards, R. L. The Basic Strengths of Some Dinitrogen Complexes of Molybdenum(0), Tungsten(0), Rhenium(I), and Osmium(II). J. Chem. Soc., Dalton Trans. 1973, 11, 1167-1172.

(8) Sellman, D.; Gerlach, R.; Jödden, K. Reaktionen an Komplexgebundenen Liganden. XXXII.: Synthese Und Eigenschaften von Heteronuklearen Mangan-Chrom-Komplexen Mit DistickstoffDiazen- Und Hydrazin-Brükenliganden. J. Organomet. Chem. 1979, 178, 433-447.

(9) (a) Mizobe, Y.; Yokobayashi, Y.; Oshita, H.; Takahashi, T.; Hidai, M. Preparation of Heterobimetallic Complexes with a Bridging Dinitrogen Ligand, $\left[\mathrm{WX}\left(\mathrm{PMe}_{2} \mathrm{Ph}\right)_{4}\left(\mu-\mathrm{N}_{2}\right) \mathrm{MCp}_{2} \mathrm{Cl}\right](\mathrm{M}=\mathrm{Ti}, \mathrm{X}=\mathrm{Cl}$; $\mathrm{M}=\mathrm{Zr}$, and $\mathrm{Hf}, \mathrm{X}=\mathrm{I})$, and X-Ray Structure of $\left[\mathrm{WI}\left(\mathrm{PMe}_{2} \mathrm{Ph}\right)_{3}(\mathrm{Py})-\right.$ $\left.\left(\mu-\mathrm{N}_{2}\right) \mathrm{ZrCp}_{2} \mathrm{Cl}\right]$ (Py = Pyridine). Organometallics 1994, 13, 37643766. (b) Ishino, H.; Nagano, T.; Kuwata, S.; Yokobayashi, Y.; Ishii, Y.; Hidai, M.; Mizobe, Y. Syntheses, Structures, and Reactivities of Heterobimetallic Bridging Dinitrogen Complexes Containing Group 6 and Group 4 or 5 Transition Metals. Organometallics 2001, 20, 188-198. (c) Ishino, H.; Takemoto, S.; Hirata, K.; Kanaizuka, Y.; Hidai, M.; Nabika, M.; Seki, Y.; Miyatake, T.; Suzuki, N. Olefin Polymerization Catalyzed by Titanium-Tungsten Heterobimetallic Dinitrogen Complexes. Organometallics 2004, 23, 4544-4546.

(10) Seymore, S. B.; Brown, S. N. Kinetic Effects in Heterometallic Dinitrogen Cleavage. Inorg. Chem. 2006, 45, 9540-9550.

(11) (a) Silverthorn, W. E. Formation of a Cationic Binuclear IronDinitrogen Compound from Molecular Nitrogen. J. Chem. Soc. D 1971, 20, 1310-1311. (b) O’Donoghue, M. B.; Zanetti, N. C.; Davis, W. M.; Schrock, R. R. Fixation” of Dinitrogen by Molybdenum and the Formation of a Trigonal Planar Iron-Tris[Molybdenum(Dinitrogen)] Complex. J. Am. Chem. Soc. 1997, 119, 2753-2754. (c) O’Donoghue, M. B.; Davis, W. M.; Schrock, R. R.; Reiff, W. M. Heterobimetallic Dinitrogen Complexes That Contain the $\left\{\left[\mathrm{N}_{3} \mathrm{~N}\right] \mathrm{Mo}-\mathrm{N}: \mathrm{N}\right\}-$ Ligand. Inorg. Chem. 1999, 38, 243-252. (d) Zhang, Q.-F.; Chim, J. L. C.; Lai, W.; Wong, W.-T.; Leung, W.-H. Bridged Dinitrogen Complexes of Iron and Chromium Porphyrins. Inorg. Chem. 2001, 40, 2470-2471. (e) Geri, J. B.; Shanahan, J. P.; Szymczak, N. K. Testing the Push-Pull Hypothesis: Lewis Acid Augmented $\mathrm{N}_{2}$ Activation at Iron. J. Am. Chem. Soc. 2017, 139, 5952-5956.

(12) Simonneau, A.; Turrel, R.; Vendier, L.; Etienne, M. Group 6 Transition-Metal/Boron Frustrated Lewis Pair Templates Activate $\mathrm{N}_{2}$ and Allow Its Facile Borylation and Silylation. Angew. Chem., Int. Ed. 2017, 56, 12268-12272.

(13) Simonneau, A.; Etienne, M. Enhanced Activation of Coordinated Dinitrogen with P-Block Lewis Acids. Chem. - Eur. J. 2018, 24, 12458-12463.

(14) (a) Fürstner, A.; Davies, P. W. Catalytic Carbophilic Activation: Catalysis by Platinum and Gold Pi Acids. Angew. Chem., Int. Ed. 2007, 46, 3410-3449. (b) Gorin, D. J.; Toste, F. D. Relativistic Effects in Homogeneous Gold Catalysis. Nature 2007, 446, 395-403. (c) Hashmi, A. S. K. Gold-Catalyzed Organic Reactions. Chem. Rev. 2007, 107, 3180-3211. (d) Li, Z.; Brouwer, C.; He, C. GoldCatalyzed Organic Transformations. Chem. Rev. 2008, 108, 32393265. (e) Jiménez-Núnez, E.; Echavarren, A. M. Gold-Catalyzed Cycloisomerizations of Enynes: A Mechanistic Perspective. Chem. Rev. 2008, 108, 3326-3350. (f) Arcadi, A. Alternative Synthetic Methods through New Developments in Catalysis by Gold. Chem. Rev. 2008, 108, 3266-3325. (g) Gold Catalysis; Toste, F. D., Michelet, V., Eds.; Imperial College Press: London, United Kingdom, 2014.

(15) Raubenheimer, H. G.; Schmidbaur, H. Gold Chemistry Guided by the Isolobality Concept. Organometallics 2012, 31, 2507-2522.
(16) Shanahan, J. P.; Szymczak, N. K. Hydrogen Bonding to a Dinitrogen Complex at Room Temperature: Impacts on $\mathrm{N}_{2}$ Activation. J. Am. Chem. Soc. 2019, 141, 8550-8556.

(17) The only relevant example of gold- $\mathrm{N}_{2}$ coordination found in the literature is the hydrazido compound $\left[(\mathrm{LAu})_{6}\left(\mathrm{~N}_{2}\right)\right]^{2+}$ with $\mathrm{L}=$ phopshine, formed from $\left[(\mathrm{LAu})_{3}(\mu-\mathrm{O})\right]^{+}$and hydrazine: Shan, $\mathrm{H}$.; Yang, Y.; James, A. J.; Sharp, P. R. Dinitrogen Bridged Gold Clusters. Science 1997, 275, 1460-1462.

(18) Stephan, D. W. The Broadening Reach of Frustrated Lewis Pair Chemistry. Science 2016, 354, aaf7229.

(19) (a) Campos, J. Dihydrogen and Acetylene Activation by a Gold(I)/Platinum(0) Transition Metal Only Frustrated Lewis Pair. J. Am. Chem. Soc. 2017, 139, 2944-2947. (b) Hidalgo, N.; Moreno, J. J.; Pérez-Jiménez, M.; Maya, C.; López-Serrano, J.; Campos, J. Evidence for Genuine Bimetallic Frustrated Lewis Pair Activation of Dihydrogen with Gold(I)/Platinum(0) Systems. Chem. - Eur. J. 2020, 26, 5982-5993.

(20) Tang, C.; Liang, Q.; Jupp, A. R.; Johnstone, T. C.; Neu, R. C.; Song, D.; Grimme, S.; Stephan, D. W. 1,1-Hydroboration and a Borane Adduct of Diphenyldiazomethane: A Potential Prelude to FLP-N 2 Chemistry. Angew. Chem., Int. Ed. 2017, 56, 16588-16592.

(21) (a) Melen, R. L. A Step Closer to Metal-Free Dinitrogen Activation: A New Chapter in the Chemistry of Frustrated Lewis Pairs. Angew. Chem., Int. Ed. 2018, 57, 880-882. (b) Ruddy, A. J.; Ould, D. M. C.; Newman, P. D.; Melen, R. L. Push and Pull: The Potential Role of Boron in $\mathrm{N}_{2}$ Activation. Dalton Trans. 2018, 47, 10377-10381.

(22) Frisch, M. J.; Trucks, G. W.; Schlegel, H. B.; Scuseria, G. E.; Robb, M. A.; Cheeseman, J. R.; Scalmani, G.; Barone, V.; Mennucci, B.; Petersson, G. A.; Nakatsuji, H.; Caricato, M.; Li, X.; Hratchian, H. P.; Izmaylov, A. F.; Bloino, J.; Zheng, G.; Sonnenberg, J. L.; Hada, M.; Ehara, M.; Toyota, K.; Fukuda, R.; Hasegawa, J.; Ishida, M.; Nakajima, T.; Honda, Y.; Kitao, O.; Nakai, H.; Vreven, T.; Montgomery, J. A., Jr.; Peralta, J. E.; Ogliaro, F.; Bearpark, M.; Heyd, J. J.; Brothers, E.; Kudin, K. N.; Staroverov, V. N.; Keith, T.; Kobayashi, R.; Normand, J.; Raghavachari, K.; Rendell, A.; Burant, J. C.; Iyengar, S. S.; Tomasi, J.; Cossi, M.; Rega, N.; Millam, J. M.; Klene, M.; Knox, J. E.; Cross, J. B.; Bakken, V.; Adamo, C.; Jaramillo, J.; Gomperts, R.; Stratmann, R. E.; Yazyev, O.; Austin, A. J.; Cammi, R.; Pomelli, C.; Ochterski, J. W.; Martin, R. L.; Morokuma, K.; Zakrzewski, V. G.; Voth, G. A.; Salvador, P.; Dannenberg, J. J.; Dapprich, S.; Daniels, A. D.; Farkas, O.; Foresman, J. B.; Ortiz, J. V.; Cioslowski, J.; Fox, D. J. Gaussian 09, revision D.01; Gaussian, Inc.: Wallingford, CT, 2013.

(23) (a) Perdew, J. P.; Chevary, J. A.; Vosko, S. H.; Jackson, K. A.; Pederson, M. R.; Singh, D. J.; Fiolhais, C. Atoms, Molecules, Solids, and Surfaces: Applications of the Generalized Gradient Approximation for Exchange and Correlation. Phys. Rev. B: Condens. Matter Mater. Phys. 1992, 46, 6671-6687. (b) Becke, A. D. Densityfunctional Thermochemistry. III. The Role of Exact Exchange. J. Chem. Phys. 1993, 98, 5648-5652.

(24) Andrae, D.; Häußermann, U.; Dolg, M.; Stoll, H.; Preuß, H. Energy-Adjusted ab Initio Pseudopotentials for the Second and Third Row Transition Elements. Theor. Chim. Acta 1990, 77, 123-141.

(25) Ehlers, A. W.; Böhme, M.; Dapprich, S.; Gobbi, A.; Höllwarth, A.; Jonas, V.; Köhler, K. F.; Stegmann, R.; Veldkamp, A.; Frenking, G. A Set of F-Polarization Functions for Pseudo-Potential Basis Sets of the Transition Metals $\mathrm{Sc}-\mathrm{Cu}, \mathrm{Y}-\mathrm{Ag}$ and $\mathrm{La}-\mathrm{Au}$. Chem. Phys. Lett. 1993, 208, 111-114.

(26) Grimme, S.; Ehrlich, S.; Goerigk, L. Effect of the Damping Function in Dispersion Corrected Density Functional Theory. J. Comput. Chem. 2011, 32, 1456-1465.

(27) (a) Reed, A. E.; Weinhold, F. Natural Bond Orbital Analysis of Near-Hartree-Fock Water Dimer. J. Chem. Phys. 1983, 78, 40664073. (b) Reed, A. E.; Curtiss, L. A.; Weinhold, F. Intermolecular Interactions from a Natural Bond Orbital, Donor-Acceptor Viewpoint. Chem. Rev. 1988, 88, 899-926.

(28) trans-Mo(dppe $)_{2}\left(\mathrm{~N}_{2}\right)_{2}$ and trans- $\mathrm{Mo}(\text { depe })_{2}\left(\mathrm{~N}_{2}\right)_{2} \quad\left(3_{\mathrm{Mo}}\right)$ prepared from $\mathrm{MoCl}_{5}$ : (a) George, T. A.; Noble, M. E. A Direct 
One-Step Preparation of Bis(Dinitrogen) Complexes of Molybdenum(0) from Molybdenum(V) Chloride. Inorg. Chem. 1978, 17, 1678-1679. trans-W(dppe $)_{2}\left(\mathrm{~N}_{2}\right)_{2} \quad\left(2_{\mathrm{W}}\right)$ prepared from $\mathrm{WCl}_{4}\left(\mathrm{PPh}_{3}\right)_{2}$ : (b) Dilworth, J. R.; Richards, R. L.; Chen, G. J.-J.; Mcdonald, J. W. The Synthesis of Molybdenum and Tungsten Dinitrogen Complexes. Inorg. Synth. 2007, 28, 33-43. cis/trans mixture of $\mathrm{Mo}\left(\mathrm{N}_{2}\right)_{2}\left(\mathrm{PMe}_{2} \mathrm{Ph}\right)_{4}\left(4_{\mathrm{Mo}}\right)$ prepared from $\mathrm{MoCl}_{3}(\mathrm{THF})_{3}$ : (c) Anker, M. W.; Chatt, J.; Leigh, G. J.; Wedd, A. G. Preparation of Trichlorotris(Tetrahydrofuran)Molybdenum(III) and Its Use in the Preparation of Complexes of Molybdenum-(III) and -(0). J. Chem. Soc., Dalton Trans. 1975, 23, 2639-2645. trans-W(depe $)_{2}\left(\mathrm{~N}_{2}\right)_{2}\left(3_{\mathrm{W}}\right)$ and cis-W $\left(\mathrm{N}_{2}\right)_{2}\left(\mathrm{PMe}_{2} \mathrm{Ph}\right)_{4}\left(\boldsymbol{4}_{\mathrm{W}}\right)$ prepared from $\mathrm{WCl}_{6}$ : (d) Coffinet, A.; Specklin, D.; Vendier, L.; Etienne, M.; Simonneau, A. Frustrated Lewis Pair Chemistry Enables $\mathrm{N}_{2}$ Borylation by Formal 1,3-Addition of a B-H Bond in the Coordination Sphere of Tungsten. Chem. - Eur. J. 2019, 25, 14300-14303. trans-W(depe $)_{2}\left({ }^{15} \mathrm{~N}_{2}\right)_{2}$ prepared from trans- $\left[\mathrm{WCl}_{2}(\text { depe })_{2}\right]$ under an ${ }^{15} \mathrm{~N}_{2}$ atmosphere: (e) Filippou, A. C.; Schnakenburg, G.; Philippopoulos, A. I.; Weidemann, N. Ge ${ }_{2}$ trapped via Triple Bonds between two Metal Centers: Syntheses and Structures of the Germylidyne Complexes trans,trans [Cl(depe $\left.{ }_{2} \mathrm{M} \equiv \mathrm{Ge}-\mathrm{Ge} \equiv \mathrm{M}(\text { depe })_{2} \mathrm{Cl}\right](\mathrm{M}=\mathrm{Mo}, \mathrm{W})$ and Bonding Analyses of the $\mathrm{M} \equiv \mathrm{Ge}-\mathrm{Ge} \equiv \mathrm{M}$ chain. Angew. Chem., Int. Ed. 2005, 44, 5979-5985.

(29) Zheng, Y.; Zhang, J.; Cheng, X.; Xu, X.; Zhang, L. Wolff Rearrangement of Oxidatively Generated $\alpha$-Oxo Gold Carbenes: An Effective Approach to Silylketenes. Angew. Chem., Int. Ed. 2019, 58, $5241-5245$.

(30) Wang, C.; Erker, G.; Kehr, G.; Wedeking, K.; Fröhlich, R. Synthesis, Structural Features, and Formation of Organometallic Derivates of C1-Bridged $\mathrm{Cp} /$ Amido Titanium and Zirconium "CpCN-Constrained Geometry" Systems. Organometallics 2005, 24, $4760-4773$.

(31) (a) Harris, R. K.; Becker, E. D.; Cabral de Menezes, S. M.; Granger, P.; Hoffman, R. E.; Zilm, K. W. Further Conventions for NMR Shielding and Chemical Shifts (IUPAC Recommendations 2008). Pure Appl. Chem. 2008, 80, 59-84. (b) Harris, R. K.; Becker, E. D.; Cabral de Menezes, S. M.; Goodfellow, R.; Granger, P. NMR Nomencalture. Nuclear Spin Properties and Conventions for Chemical Shifts. Pure Appl. Chem. 2001, 73, 1795-1818.

(32) (a) N-Heterocyclic Carbenes: Effective Tools for Organometallic Synthesis; Nolan, S. P., Ed.; Wiley-VCH Verlag GmbH \& Co. KGaA: Weinheim, Germany, 2014. (b) Nolan, S. P. The Development and Catalytic Uses of N-Heterocyclic Carbene Gold Complexes. Acc. Chem. Res. 2011, 44, 91-100.

(33) (a) Baker, M. V.; Barnard, P. J.; Brayshaw, S. K.; Hickey, J. L.; Skelton, B. W.; White, A. H. Synthetic, Structural and Spectroscopic Studies of (Pseudo)Halo(1,3-Di-Tert-Butylimidazol-2-Ylidine)Gold Complexes. Dalton Trans. 2005, 1, 37-43. (b) Mézailles, N.; Ricard, L.; Gagosz, F. Phosphine Gold(I) Bis-(Trifluoromethanesulfonyl)Imidate Complexes as New Highly Efficient and Air-Stable Catalysts for the Cycloisomerization of Enynes. Org. Lett. 2005, 7, 4133-4136. (c) Kumar, M.; Jasinski, J.; Hammond, G. B.; Xu, B. Alkyne/Alkene/ Allene-Induced Disproportionation of Cationic Gold(I) Catalyst. Chem. - Eur. J. 2014, 20, 3113-3119.

(34) Tuczek, F.; Horn, K. H.; Lehnert, N. Vibrational Spectroscopic Properties of Molybdenum and Tungsten N2 and N2Hx Complexes with Depe Coligands: Comparison to Dppe Systems and Influence of H-Bridges. Coord. Chem. Rev. 2003, 245, 107-120. and references therein.

(35) Biasiolo, L.; Trinchillo, M.; Belanzoni, P.; Belpassi, L.; Busico, V.; Ciancaleoni, G.; D’Amora, A.; Macchioni, A.; Tarantelli, F.; Zuccaccia, D. Unexpected Anion Effect in the Alkoxylation of Alkynes Catalyzed by N-Heterocyclic Carbene (NHC) Cationic Gold Complexes. Chem. - Eur. J. 2014, 20, 14594-14598.

(36) Hussain, W.; Leigh, G. J.; Ali, H. M.; Pickett, C. J.; Rankin, D. A. Dinitrogen Binding and Electrochemistry in Complexes of Molybdenum and Tungsten. J. Chem. Soc., Dalton Trans. 1984, $1703-1708$.
(37) (a) Jia, M.; Bandini, M. Counterion Effects in Homogeneous Gold Catalysis. ACS Catal. 2015, 5, 1638-1652. (b) Ciancaleoni, G.; Belpassi, L.; Zuccaccia, D.; Tarantelli, F.; Belanzoni, P. Counterion Effect in the Reaction Mechanism of NHC Gold(I)-Catalyzed Alkoxylation of Alkynes: Computational Insight into Experiment. ACS Catal. 2015, 5, 803-814. (c) Lu, Z.; Han, J.; Okoromoba, O. E.; Shimizu, N.; Amii, H.; Tormena, C. F.; Hammond, G. B.; Xu, B. Predicting Counterion Effects Using a Gold Affinity Index and a Hydrogen Bonding Basicity Index. Org. Lett. 2017, 19, 5848-5851. (d) Schießl, J.; Schulmeister, J.; Doppiu, A.; Wörner, E.; Rudolph, M.; Karch, R.; Hashmi, A. S. K. An Industrial Perspective on Counter Anions in Gold Catalysis: On Alternative Counter Anions. Adv. Synth. Catal. 2018, 360, 3949-3959.

(38) Average $\mathrm{W}-\mathrm{P}$ and $\mathrm{W}-\mathrm{Cl}$ distances for $\left[\mathrm{W}(\mathrm{Cl})_{2}(\text { dppe })_{2}\right]=$ $2.50 \AA$ and $2.42 \AA$ : (a) Filippou, A. C.; Schnakenburg, G.; Philippopoulos, A. I. Trans-Dichlorobis[Ethane-1,2-Diylbis(Diphenylphophine) $\left.-\kappa^{2} \mathrm{P}, \mathrm{P}^{\prime}\right]$ tungsten(II) Pentane Hemisolvate. Acta Crystallogr., Sect. E: Struct. Rep. Online 2003, 59, m602-m604. Average $\mathrm{W}-\mathrm{P}$ and $\mathrm{W}-\mathrm{Cl}$ distances for $\left[\mathrm{W}(\mathrm{Cl})_{2}(\mathrm{dppe})_{2}\right][\mathrm{X}](\mathrm{X}=$ $\left.\mathrm{BF}_{4}^{-}, \mathrm{PF}_{6}^{-}\right)=2.54 \AA$ and $2.32 \AA$ : (b) Imaeda, M.; Nishihara, H.; Nakano, K.; Ichida, H.; Kobayashi, A.; Saito, T.; Sasaki, Y. Reactions of $\left[\mathrm{W}\left(\mathrm{N}_{2}\right)_{2}(\mathrm{Dpe})_{2}\right]$ with $\mathrm{HFeCo}_{3}(\mathrm{CO})_{12}$ in Aqueous and Halogenated Solvents to Form Hydrazido(2-) Hydroxo Complexes of Tungsten(IV) and Dihalo Complexes of Tungsten(III). Crystal Structure of $\left[\mathrm{WCl}_{2}(\mathrm{Dpe})_{2}\right] \mathrm{BF}_{4} \cdot 1 / 3 \mathrm{CH}_{2} \mathrm{Cl}_{2}$. Inorg. Chem. 1985, 24, 1246-1250. (c) Jayarathne, U.; Chandrasekaran, P.; Greene, A. F.; Mague, J. T.; DeBeer, S.; Lancaster, K. M.; Sproules, S.; Donahue, J. P. X-Ray Absorption Spectroscopy Systematics at the Tungsten LEdge. Inorg. Chem. 2014, 53, 8230-8241.

(39) Gaillard, S.; Nun, P.; Slawin, A. M. Z.; Nolan, S. P. Expeditious Synthesis of $\mathrm{Au}(\mathrm{NHC})(\mathrm{L})(+)(\mathrm{NHC}=\mathrm{N}-H e t e r o c y c l i c$ Carbene; $\mathrm{L}$ = Phosphine or NHC) Complexes. Organometallics 2010, 29, 54025408.

(40) (a) Azizian, H.; Luck, R.; Morris, R. H.; Wong, H. Dinitrogen versus H6-Arene Coordination in Methyldiphenylphosphine Complexes of Molybdenum(0). J. Organomet. Chem. 1982, 238, C24-C26. (b) Luck, R.; Morris, R. H. Reversible Binding of Dinitrogen and Dihydrogen by ( $\eta^{6}$-Phenylmethylphenylphosphine)Tris(Methyldiphenylphosphine)Molybdenum ( $\mathrm{Mo}\left(\eta^{6}-\mathrm{PhPMePh}\right)$ $(\mathrm{PMePh} 2) 3)$ : Use of $[9-\mathrm{BBN}] 2$ as a Phosphine Sponge Reagent. Inorg. Chem. 1984, 23, 1489-1491.

(41) The peculiar shape of the $\mathrm{N}_{2}$ ligand in the figure is caused by a disorder of the two axial ligands within the crystal lattice.

(42) de Frémont, P.; Marion, N.; Nolan, S. P. Cationic NHCGold(I) Complexes: Synthesis, Isolation, and Catalytic Activity. J. Organomet. Chem. 2009, 694, 551-560.

(43) Gómez-Suárez, A.; Nelson, D. J.; Nolan, S. P. Quantifying and Understanding the Steric Properties of N-Heterocyclic Carbenes. Chem. Commun. 2017, 53, 2650-2660.

(44) Mean Mo-N double bonds $=1.752 \AA(\mathrm{SD}=0.0485 \AA)$ gathered from 760 structures of the SCD database. Mean W-N double bonds $=1.771 \AA(\mathrm{SD}=0.0641 \AA$ ) gathered from 546 structures of the SCD database.

(45) Idipp* = 1,3-bis(2,6-bis(diphenylmethyl)-4-methylphenyl) imidazol-2-ylidene. Veenboer, R. M. P.; Gasperini, D.; Nahra, F.; Cordes, D. B.; Slawin, A. M. Z.; Cazin, C. S. J.; Nolan, S. P. Expedient Syntheses of Neutral and Cationic $\mathrm{Au}(\mathrm{I})-\mathrm{NHC}$ Complexes. Organometallics 2017, 36, 3645-3653.

(46) Piascik, A. D.; Hill, P. J.; Crawford, A. D.; Doyle, L. R.; Green, J. C.; Ashley, A. E. Cationic Silyldiazenido Complexes of the $\mathrm{Fe}$ (Diphosphine $)_{2}\left(\mathrm{~N}_{2}\right)$ Platform: Structural and Electronic Models for an Elusive First Intermediate in $\mathrm{N}_{2}$ Fixation. Chem. Commun. 2017, 53, 7657-7660.

(47) Green, M. L. H.; Silverthorn, W. E. The $\mu$-Dinitrogen-bis $\{[1,2-$ Bis (Dimethylphosphino) Ethane $]$ Hydrido- $[\eta-(1,3,5$ Trimethylbenzene)]Molybdenum $\}$ Cation. J. Chem. Soc., Dalton Trans. 1974, 20, 2164-2166.

(48) Chatt, J.; Fay, R. C.; Richards, R. L. Preparation and Characterisation of the Dinuclear Dinitrogen Complex, Trichloro- $\mu$ - 
Dinitrogen-Bis(Tetrahydrofuran) \{chlorotetrakis[Dimethyl-(Phenyl)$\mathrm{Phosphine]} \mathrm{Rhenium} \mathrm{(I)}\} \mathrm{chromium}$ ( III)$\left[\left(\mathrm{PMe}_{2} \mathrm{Ph}\right)_{4} \mathrm{ClReN}_{2} \mathrm{CrCl}_{3}(\mathrm{Thf})_{2}\right]$. J. Chem. Soc. A 1971, 0, 702-704.

(49) Selected examples: (a) Welch, G. C.; Coffin, R.; Peet, J.; Bazan, G. C. Band Gap Control in Conjugated Oligomers via Lewis Acids. J. Am. Chem. Soc. 2009, 131, 10802-10803. B-N = $1.557 \AA$.

(b) Herrmann, H.; Fillol, J. L.; Gehrmann, T.; Enders, M.; Wadepohl, H.; Gade, L. H. Bonding and Bending in Zirconium(IV) and Hafnium(IV) Hydrazides. Chem. - Eur. J. 2008, 14, 8131-8146. B-N $=1.562 \AA$.

(50) Selected examples: (a) Welch, G. C.; Coffin, R.; Peet, J.; Bazan, G. C. Band Gap Control in Conjugated Oligomers via Lewis Acids. J. Am. Chem. Soc. 2009, 131, 10802-10803. B-N = $1.557 \AA$. (b) Herrmann, H.; Fillol, J. L.; Gehrmann, T.; Enders, M.; Wadepohl, H.; Gade, L. H. Bonding and Bending in Zirconium(IV) and Hafnium(IV) Hydrazides. Chem. - Eur. J. 2008, 14, 8131-8146. B-N $=1.562 \AA$.

(51) Toyota, S.; Oki, M. Structure of Intramolecular Boron-Amine Complexes and Proposal of Tetrahedral Character for Correlation between Molecular Structure and Barrier to Dissociation of the N-B Bonds. Bull. Chem. Soc. Jpn. 1992, 65, 1832-1840.

(52) Donovan-Mtunzi, S.; Richards, R. L.; Mason, J. Nitrogen-15 Nuclear Magnetic Resonance Spectroscopy of Dinitrogen-bridged complexes. J. Chem. Soc., Dalton Trans. 1984, 2429-2433.

(53) Dilworth, J. R. Diazene, Diazenido, Isodiazene and Hydrazido Complexes. Coord. Chem. Rev. 2017, 330, 53-94.

(54) (a) Comas-Vives, A.; Harvey, J. N. How Important Is Backbonding in Metal Complexes Containing N-Heterocyclic Carbenes? Structural and NBO Analysis. Eur. J. Inorg. Chem. 2011, 2011, 5025-5035. (b) Marchione, D.; Belpassi, L.; Bistoni, G.; Macchioni, A.; Tarantelli, F.; Zuccaccia, F. The Chemical Bond in Gold(I) Complexes with N-Heterocyclic Carbenes. Organometallics 2014, 33, 4200-4208. (c) Frenking, G.; Sola, M.; Vyboishchikov, S. F. Chemical bonding in transition metal carbene complexes. $J$. Organomet. Chem. 2005, 690, 6178-6204. (d) Nemcsok, D.; Wichmann, K.; Frenking, G. The Significance of $\pi$ Interactions in Group 11 Complexes with N-Heterocyclic Carbenes. Organometallics 2004, 23, 3640-3646.

(55) Fontaine, P. P.; Yonke, B. L.; Zavalij, P. Y.; Sita, L. R. Dinitrogen Complexation and Extent of $\mathrm{N} \equiv \mathrm{N}$ Activation within the Group 6 "End-On-Bridged" Dinuclear Complexes, $\left\{\left(\eta^{5}-\mathrm{C}_{5} \mathrm{Me}_{5}\right) \mathrm{M}\right.$ $[\mathrm{N}(i-\operatorname{Pr}) \mathrm{C}(\mathrm{Me}) \mathrm{N}(i-\mathrm{Pr})]\}_{2}\left(\mu-\eta^{1}: \eta^{1}-\mathrm{N}_{2}\right) \quad(\mathrm{M}=\mathrm{Mo}$ and $\mathrm{W})$. J. Am. Chem. Soc. 2010, 132, 12273-12285.

(56) Jerabek, P.; Roesky, H. W.; Bertrand, G.; Frenking, G. Coinage Metals Binding as Main Group Elements: Structure and Bonding of the Carbene Complexes $\left[\mathrm{TM}(\mathrm{CAAC})_{2}\right]$ and $\left[\mathrm{TM}(\mathrm{CAAC})_{2}\right]^{+}(\mathrm{TM}=$ $\mathrm{Cu}, \mathrm{Ag}, \mathrm{Au})$. J. Am. Chem. Soc. 2014, 136, 17123-17135. 